\title{
PURIFICAÇÃO E INVESTIGAÇÃO DAS PROPRIEDADES FÍSICO-QUÍMICAS DE INIBIDORES DE PROTEASES EXTRAÍDOS DE SEMENTES DE Acacia plumosa Lowe
}

\author{
José Luiz de Souza Lopes
}

\begin{abstract}
Dissertação apresentada ao Instituto de Física de São Carlos, da Universidade de São Paulo, para obtenção do título de Mestre em Ciências, área Física Aplicada - opção Física Biomolecular.
\end{abstract}

Orientadora: Prof. Dra. Leila Maria Beltramini

São Carlos

2006 
“A maravilhosa disposição e harmonia do universo só pode ter tido origem segundo o plano de um Ser que tudo sabe e tudo pode"

Isaac Newton 
À minha inesquecível irmã Valéria Lopes por sua luta pela vida e por seu grande carinho comigo. 


\section{Agradecimentos}

- A Deus, por me ter feito conhecer o seu amor, pelas grandes oportunidades a mim concedidas e por sua infalível providência;

- À Prof. Dra. Leila Maria Beltramini, pela sua orientação desde a iniciação científica como no presente trabalho, por sua amizade e principalmente por acreditar em minha capacidade;

- À Prof. Dra. Heloisa Sobreiro S. de Araújo, pela sua disposição em colaborar com este trabalho nos seqüenciamentos;

- Ao Prof. Dr. José César Rosa pela colaboração nos experimentos de espectrometria de massa;

- À Prof. Dra. Maria Luiza V. Oliva, pelas contribuições nas conversas durante as reuniões da SBBq, e por nos ceder amostras de BAPNA;

- Aos professores Odair José Pereira, Silvana Perissatto Meneghin e Vânia Maria Maciel Melo por nos doarem esporos dos fungos fitopatogênicos;

- Aos técnicos da Biofisica: Bel, pela grande colaboração em todas as etapas deste trabalho, desde a coleta das sementes até o ultimo ensaio realizados com fungos; Andressa, pela disposição para ajudar nas medidas espectroscópicas, para discutir técnicas novas e pelas conversas; Beto, por sua prontidão para ajudar com os equipamentos e microcomputador; e também João, pela simpatia e prontidão;

- Às técnicas Bianca e Susana do grupo de Cristalografia do IFSC pela simpatia e disposição em ajudar; 
- Às funcionárias da Secretaria de Pós-Graduação Wladerez e Cristiane, pelo atendimento sempre simpático e eficiente;

- Ao doutorando Napoleão Valadares do grupo de Cristalografia do IFSC pela colaboração nos experimentos de SPR;

- Aos professores do grupo de Biofísica Molecular "Sergio Mascarenhas”: Ana Paula, Jabáh, Nelma e Otaciro;

- Aos meus grandes amigos da Biofisica que dão ao grupo um ambiente de trabalho muito agradável: Cris, Melissa, Leandro, Fernando(s), Ana Paula, Ceará, Fernanda, Roseane, Priscila, Daiane, Wânius, Marli, Marcel, Lia, Kelven, Julio, Dani(s), Luis e Militar. De um modo muito especial aos amigos mais próximos Sheila, Júlio, Assuero, Célia e Débora pela ajuda que me forneceram com conversas, reuniões e discussões; e também aos meus amigos da graduação Ariane, Meiri, Alex, Fabiana, Marta e Débora;

- Aos meus pais, José e Dora, pela formação do meu caráter e por todo o tipo de apoio que me foi fornecido. Às minhas irmãs, sempre prestativas, confiantes e dispostas a ensinar e aprender;

- Ao CNPq e à FAPESP pelo suporte financeiro para a realização deste trabalho. 


\section{SUMÁRIO}

Dedicatória

Agradecimentos

LISTA DE FIGURAS

LISTA DE TABELAS

LISTA DE ABREVIATURAS E SÍMBOLOS

RESUMO

ABSTRACT

I - INTRODUCÃO

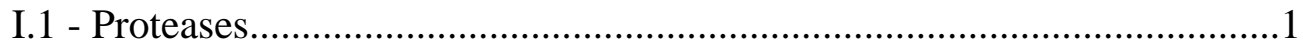

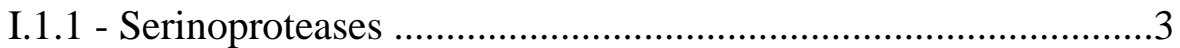

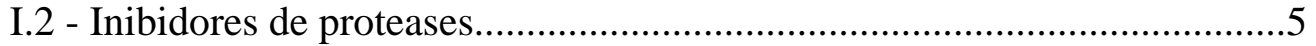

I.2.1 - Inibidores de serinoproteases ..............................................

I.2.1.1 - Família Bowman-Birk .............................................9

I.2.1.2 - Família Batata I e Batata II ........................................9

I.2.1.3 - Família Abóbora .......................................................10

I.2.1.4 - Família Kunitz ........................................................10

I.2.2 - Inibidores de proteases na família Leguminosae ...................11

I.3 - O gênero Acacia ...................................................................................12

I.3.1 - A espécie Acacia plumosa Lowe............................................ 13

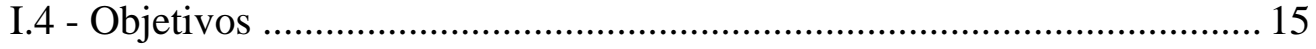

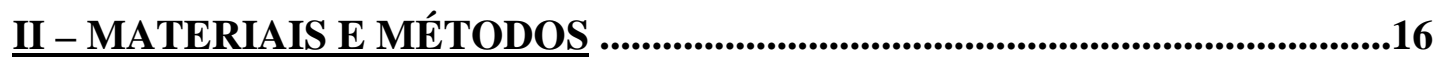

II.1 - MATERIAIS .......................................................16

II.1.1 - Materiais e Equipamentos utilizados .....................................16

II.1.2 - Reagentes, resinas e soluções utilizados ..............................18

II.2 - MÉTODOS .............................................................19

II.2.1 - Obtenção do extrato bruto (EB) ...........................................19

II.2.2 - Purificação do Inibidor ........................................................21

II.2.2.1 - Cromatografia de Exclusão Molecular.....................21

II.2.2.2 - Cromatografia de Troca Iônica ...............................21

II.2.2.3 - Eletroforese em Gel de Poliacrilamida ...................222

II.2.2.4 - Cromatografia de Fase Reversa................................23

II.2.2.5 - Determinação das proteínas totais do extrato bruto e quantificação dos inibidores ...............................23 
II.2.3 - Análise físico-química e estrutural das isoformas dos inibidores

II.2.3.1 - Determinação do Ponto Isoelétrico .......................... 24

II.2.3.2 - Formação do Complexo enzima-inibidor .................25 II.2.3.2.1 - Determinação de $\mathrm{K}_{\mathrm{A}}$ e $\mathrm{K}_{\mathrm{D}}$ do complexo enzima-inibidor ......................................25

II.2.3.2.1 - Ensaio com tripsina................27

II.2.3.2.1 - Ensaio com quimotripsina .....27

II.2.3.3 - Determinação da Seqüência N-Terminal ................28

II.2.3.4 - Espectrometria de Massas ....................................... 29

II.2.3.5 - Espectroscopia de dicroísmo circular (CD) e cálculo das frações de estrutura secundária ......................... 31

II.2.3.6 - Espectroscopia de fluorescência ...............................33

II.2.3.7 - Ensaio de estabilidade frente a variações de pH...... 35

II.2.3.8 - Ensaio de estabilidade térmica .................................. 36

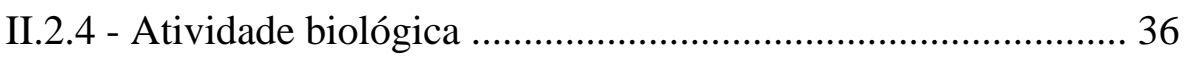

II.2.4.1 - Atividade anticoagulante....................................... 36

II.2.4.2 - Atividade de inibição de enzimas ........................... 37

II.2.4.3 - Atividade sobre fungos fitopatogênicos .................. 38

III - RESULTADOS E DISCUSSÕES

III.1 - Obtenção do extrato bruto (EB) ........................................................40

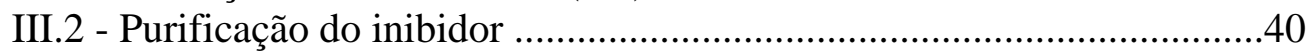

III.2.1 - Cromatografia de Exclusão Molecular...................................40

III.2.2 - Cromatografia de Troca Iônica.............................................42

III.2.3 - Eletroforese em Gel de Poliacrilamida ..................................44

III.2.4 - Cromatografia de Interação Hidrofóbica.................................46

III.2.5 - Determinação das proteínas totais do extrato bruto e quantificação dos inibidores ............................................50

III.3 - Analise físico-química e estrutural das isoformas dos inibidores ....... 51

III.3.1 - Determinação do Ponto Isoelétrico..........................................51

III.3.2 - Formação do Complexo enzima-inibidor.............................. 52

III.3.2.1 - Determinação de $\mathrm{K}_{\mathrm{A}}$ e $\mathrm{K}_{\mathrm{D}}$ do complexo enzima-inibidor ........................................................54

III.3.2.1.1 - Ensaio com tripsina .............................54

III.3.2.1.2 - Ensaio com quimotripsina ....................56

III.3.3 - Determinação da Seqüência N-Terminal..............................59

III.3.4 - Espectrometria de Massas .....................................................61

III.3.5 - Espectroscopia de dicroísmo circular (CD) e cálculo do conteúdo de estrutura secundária ........................................64

III.3.6 - Espectroscopia de fluorescência............................................ 67

III.3.7 - Ensaio de estabilidade frente a variações de $\mathrm{pH}$.....................68

III.3.8 - Ensaio de estabilidade térmica................................................ 71

III.4 - Atividade biológica....................................................................... 74

III.4.1 - Atividade anticoagulante.................................................... 74

III.4.2 - Atividade de inibição de enzimas.........................................76

III.4.3 - Atividade sobre fungos fitopatogênicos................................ 76 


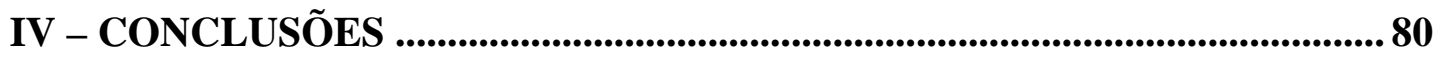

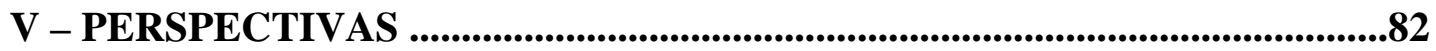

VI - REFERÊNCIAS BIBLIOGRÁFICAS ....................................................83 


\section{LISTA DE FIGURAS}

Figura 1 Mecanismo da reação catalisada por serinoproteases ......................... 4

Figura 2 Ilustração da espécie de Acacia plumosa Lowe .................................. 14

Figura 3 Obtenção do extrato bruto das sementes de Acacia plumosa .............. 20

Figura $4 \quad$ Espectro de CD de vários tipos de estrutura secundária .................... 32

Figura 5 Diagrama de Jablonski ......................................................... 34

Figura 6 Cromatografia de exclusão molecular do EB de A. plumosa .............. 41

Figura 7 Determinação do peso molecular aparente de ApPIII ........................ 42

Figura 8 Perfil cromatográfico de ApPIII em coluna de troca iônica ................ 43

Figura 9 SDS-PAGE das frações provenientes das etapas cromatográficas ..... 45

Figura 10 Perfil cromatográfico dos inibidores em condições nativas em $C_{18} \ldots . \quad 47$

Figura 11 Perfil cromatográfico de ApTIB reduzida e alquilada em $\mathrm{C}_{18} \ldots \ldots \ldots \ldots . . .49$

Figura 12 SDS-PAGE das frações provenientes das reação de redução e alquilação das cadeias de ApTIB

Figura 13 Ensaio de focalização isoelétrica de ApPIII e dos inibidores de A.plumosa

Figura 14 Eluição do complexo enzima-inibidor em Superdex-75

Figura 15 Sensorgramas da interação de ApTIA, ApTIB e ApTIC com tripsina

Figura 16 Sensorgramas da interação de ApTIA, ApTIB e ApTIC com quimotripsina 
Figura 17 Sensorgramas da interação de ApTIA com tripsina e com quimotripsina

Figura 18 Seqüência N-Terminal das três isoformas de inibidores de proteases A. plumosa

Figura 19 Alinhamento seqüencial múltiplo da região $\mathrm{N}$-Terminal dos inibidores de A.plumosa

Figura 20 Determinação da massa molecular de ApPIII, por ESI-MS, em condições nativas

Figura 21 Peptide Mass Fingerprint de ApPIII (reduzida e alquilada) obtida por ESI-MS

Figura 22 Alinhamento seqüencial de peptídeos da região interna de ApPIII com outros inibidores de serinoproteases.

Figura 23 Espectro de CD dos inibidores de protease de A.plumosa

Figura 24 Espectros de emissão de fluorescência dos inibidores de proteases de A.plumosa

Figura 25 Espectros de CD do ensaio de estabilidade frente a variações de $\mathrm{pH}$

Figura 26 Espectros de emissão de fluorescência do ensaio de estabilidade de $\mathrm{pH}$

Figura 27 Espectros de CD do ensaio de estabilidade térmica

Figura 28 Curvas de desnaturação térmica dos inibidores

Figura 29 Espectros de CD de ApTIC em antes e depois do ensaio de desnaturação térmica

Figura 30 Inibição do crescimento de fungos em microplaca de 96 poços

Figura 31 Inibição do crescimento de fungos em placas de Petri 


\section{LISTA DE TABELAS}

Tabela 1 As famílias de proteínas inibidoras de serinoproteases.

Tabela 2 Rendimento de inibidores de protease pertencentes à família Leguminosae

Tabela 3 Constantes de interação dos inibidores de A.plumosa com tripsina calculadas com o software BiaEvaluation.

Tabela 4 Constantes de interação dos inibidores de A.plumosa com quimotripsina calculadas com o software BiaEvalation.

Tabela 5 Frações de estrutura secundária das isoformas dos inibidores de protease de A.plumosa calculadas com o pacote de desconvolução CDPro

Tabela 6 Tempo de retardamento da coagulação sangüínea dos inibidores de A.plumosa 
LISTA DE ABREVIATURAS E SÍMBOLOS

Símbolo dos aminoácidos

Código de 3 letras Código de 1 letra Nome do aminoácido

Ala

Arg

Asn

Asp

Cys

Gln

Glu

Gly

His

Iso

Leu

Lys

Met

Phe

Pro

Ser

Thr

Trp

Tyr

Val
A

R

N

D

C

Q

E

G

H

I

L

K

M

F

P

S

T

W

Y

V
Alanina

Arginina

Asparagina

Aspartato

Cisteína

Glutamina

Glutamato

Glicina

Histidina

Isoleucina

Leucina

Lisina

Metionina

Fenilalanina

Prolina

Serina

Treonina

Triptofano

Tirosina

Valina

\section{Abreviaturas}

4-VP

ACB

ACN

AcTI

AeTI

ApTIA 4-vinil-piridina

Anidrase carbônica

Acetonitrila

Acacia confusa Trypsin Inhibitor

Acacia elata Trypsin Inhibitor

Acacia plumosa Trypsin Inhibitor - isoforma A 
ApTIB

ApTIC

ApTID

BAPNA

BD

BDA

BLAST

BSA

BvcTI

BvlTI

CD

Cit C

D.O.

DTT

EB

EcTI

EDC

EDTA

ESI-MS

HPLC

IEF

ITS

$\mathbf{k}_{\mathbf{a}}$

$\mathbf{k}_{\mathbf{d}}$

$\mathbf{K}_{\mathrm{A}}$

$K_{D}$

LITI

$\mathbf{m} / \mathbf{z}$

$\mathbf{m} / \mathbf{v}$

NCBI

NHS
Acacia plumosa Trypsin Inhibitor - isoforma B

Acacia plumosa Trypsin Inhibitor - isoforma C

Acacia plumosa Trypsin Inhibitor - isoforma D

Benzoil--D,L-Arginine-p-NitroAnilide

Meio de cultura para crescimento de fungos contento batata e dextrose (meio líquido)

Meio de cultura para crescimento de fungos contento batata, dextrose e ágar (meio sólido)

Basic Local Alignment Search Tool

Albumina sérica bovina

Bauhinia variegata var. candida Trypsin Inhibitor

Bauhinia variegata var. lilac Trypsin Inhibitor

Circular Dichroism, dicroísmo circular

Citocromo C

Densidade Óptica

Ditiotreitol

Extrato bruto

Enterolobium contortisiliquum Trypsin Inhibitor

N-etil-N-(3-dimetilaminopropil)carbodiimida

Ácido etileno diamino tetracético

Electros Spray Ionization - Mass Spectrometry, Espectrometria de massa por ionização etéctron-spray

High performance liquid chromatography, cromatografia líquida de alto desempenho

IsoEletric Focussing, Focalização Isoelétrica

Inibidor de tripsina de soja

taxa de associação

taxa de dissociação

Constante de associação $\left(\mathrm{k}_{\mathrm{a}} / \mathrm{k}_{\mathrm{d}}\right)$

Constante de dissociação $\left(\mathrm{k}_{\mathrm{d}} / \mathrm{k}_{\mathrm{a}}\right)$

Leucaena leucocephala trypsin inhibitor

Massa por carga

Massa por volume

National Center for Biotechnology Information

N-hidroxisuccinimida 
OVA Ovalbumina

PBS Phosfate Buffer Saline, tampão fosfato salino

pI

Ponto isoelétrico

PjTI

Prosopis juliflora trypsin inhibitor

RMS

Root mean square, desvio médio quadrático

RU

Unidades de Ressonância

SDS-PAGE

Sodium DodecylSulphate - Polyacrilamide Gel

Electrophpresis, eletroforese em gel de poliacrilamidaSDS

SELCON, Continll e Programas de análise de espectros de CD que estimam o CDSSTR conteúdo de estrutura secundária de uma proteína

SPR

Surface Plasmon Ressonance, Ressonância Plasmônica de Superfície

STI

Soybean Trypsin Inhibitor

u.a.

Unidade arbitrária 


\section{RESUMO}

Sementes das plantas pertencentes à família Leguminosae são excelentes fontes de inibidores de proteases. O gênero Acacia é um dos membros mais importantes deste grupo. Neste trabalho, foram descritos novos inibidores de proteases das sementes de Acacia plumosa Lowe. A partir do extrato salino das sementes maduras, os inibidores foram purificados por cromatografia de exclusão molecular em coluna Superdex-75 (equilibrada e eluída com PBS) e cromatografia de troca iônica em coluna Mono-S, equilibrada e eluída com o tampão Acetato de Sódio $50 \mathrm{mM}$ (pH 5.0) num gradiente linear de $\mathrm{NaCl}$ 0-0.5 M. Quatro frações (eluídas por volta de 0.18, 0.22, 0.33 e $0.37 \mathrm{M}$ de $\mathrm{NaCl}$ ) apresentaram atividade anticoagulante e ação inibitória sobre serinoproteases, estas frações foram denominadas ApTIA, ApTIB, ApTIC e ApTID, respectivamente. Em condições nativas, a espectrometria de massas mostrou as massas moleculares de três deles (A, B e C): 19.709; 19.869 e 20.378 Dáltons, enquanto que em SDS-PAGE na presença de $\beta$-mercaptoethanol, foram observadas duas cadeias para cada um dos inibidores. A análise dos primeiros 10 resíduos de aminoácidos da região N-Terminal das duas cadeias das formas A, B, C revelou identidade com inibidores do tipo Kunitz, e também mostrou dois resíduos diferentes na ApTIC, em relação as formas A e B. Estes dados levam a interpretação de que estes inibidores são diferentes isoformas encontradas nesta semente. Os espectros de dicroísmo circular foram compatíveis com proteínas que majoritariamente apresentam elementos- $\beta$ e não-ordenados em sua estrutura, apresentando máximos positivos por volta de 230 nm e mínimos em 202 nm. Os três isoinibidores foram muito estáveis em pHs ácidos e alcalinos, e suas estruturas foram afetadas somente acima de $75^{\circ} \mathrm{C}$. As constantes de associação $\left(\mathrm{K}_{\mathrm{A}}\right)$ e de dissociação $\left(\mathrm{K}_{\mathrm{D}}\right)$ determinadas por SPR (num sistema BIACORE) com enzimas proteolíticas indicaram que a afinidade destes inibidores por tripsina foi até 20 vezes maior que para quimotripsina (tripsina: $\mathrm{K}_{\mathrm{A}} 2.57_{\mathrm{x}} 10^{9} \mathrm{M}^{-1}$ e quimotripsina: $\mathrm{K}_{\mathrm{A}} 1.34_{\mathrm{x}} 10^{8} \mathrm{M}^{-1}$ ), e o complexo tripsina-inibidor mostrou maior estabilidade (tripsina: $\mathrm{K}_{\mathrm{D}}$ por volta de 0,5 nM e quimotripsina: $6 \mathrm{nM}$ ). Estes inibidores também apresentaram ação inibitória sobre o crescimento dos fungos Aspergillus niger, Thielaviopsis paradoxa, Colletotrichum sp P10 e Fusarium moniliforme, mostrando que provavelmente a inibição de suas serinoproteases possa ser um mecanismo de controle das suas proliferações. 


\begin{abstract}
Seeds of plants belonging to Leguminosae family are rich sources of protease inhibitors. The Acacia genus is one of the most important members of this group. In this work, novel protease inhibitors from Acacia plumose Lowe seeds have been described. From the saline extract of mature seeds, the inhibitors were purified by size exclusion chromatography on Superdex-75 column (equilibrated and eluted with PBS) and ionic exchange chromatography on Mono-S column, equilibrated and eluted with Sodium Acetate $50 \mathrm{mM}(\mathrm{pH}$ 5.0) in a linear gradient of $\mathrm{NaCl} 0-0.5 \mathrm{M}$. Four fractions (eluted around $0.18,0.22,0.33$ and $0.37 \mathrm{M}$ of $\mathrm{NaCl}$ ) presented anticoagulant activity and inhibitory action on serineprotease, these fractions were denoted ApTIA, ApTIB, ApTIC and ApTID, respectively. In native conditions, mass spectrometry showed the molecular weights of three of them (A, B and C): 19,709; 19,869 and 20,378 Daltons, while in SDS-PAGE in $\beta$-mercaptoethanol presence, two chains for each inhibitor were observed. The N-terminal analysis of the first 10 amino acid residues of both chains of the isoforms A, B, and C revealed identity with Kunitz protease inhibitors and also showed two different residues in ApTIC, comparing with $\mathrm{A}$ and $\mathrm{B}$ isoforms. These data indicate that the inhibitors are different isoforms present in this seeds. The circular dichroism spectra were compatible with proteins that majority present unordered and beta-elements in these structures, presenting positive maxima around $230 \mathrm{~nm}$ and minima about $202 \mathrm{~nm}$. The three isonhibitors were very stable at acids and alkalines $\mathrm{pH}$, and their structures are only affected over $75^{\circ} \mathrm{C}$. The association $\left(\mathrm{K}_{\mathrm{A}}\right)$ and dissociation constants $\left(\mathrm{K}_{\mathrm{D}}\right)$ determined by SPR (BIACORE system) with proteolytic enzymes indicated that the affinity of these inhibitors for trypsin was up to 20 times bigger than for chymotrypsin (trypsin: $\mathrm{K}_{\mathrm{A}} 2.57_{\mathrm{x}} 10^{9} \mathrm{M}^{-1}$ and chymotrypsin: $\mathrm{K}_{\mathrm{A}} 1.37_{\mathrm{x}} 10^{8} \mathrm{M}^{-1}$ ), and the complex inhibitor-trypsin showed higher stability (trypsin: $K_{D}$ around 0,5 $\mathrm{nM}$ and chymotrypsin: $6 \mathrm{nM}$ ). These inhibitors also presented inhibitory action on the fungi growth of Aspergillus niger, Thielaviopsis paradoxa, Colletotrichum sp P10 e Fusarium moniliforme showing that probably the inhibition of their serineproteases can be a mechanism of control of their proliferation.
\end{abstract}




\section{$\underline{\text { I - INTRODUCÃ̃ }}$}

\section{1 - Proteases}

Proteases, também denominadas peptidases, são enzimas proteolíticas que catalisam a clivagem hidrolítica da ligação peptídica presentes em outras proteínas e polipeptídeos, resultando em peptídeos menores ou aminoácidos (Neurath, 1993).

Elas contabilizam cerca de $2 \%$ do genoma humano, e estão envolvidas em numerosos processos fisiológicos importantes, como por exemplo, a síntese de todas as proteínas, o controle do tamanho da proteína, liberação de hormônios precursores, translocação através de membranas, reaproveitamento de aminoácidos (turnover), digestão, sinalização celular, coagulação sangüínea, fertilização, diferenciação e crescimento celular, resposta imune e apoptose (Powers, 2002; Chou, 2006).

As enzimas proteolíticas são essenciais em vírus, bactérias e parasitas para sua replicação e propagação das doenças infecciosas (Chou, 2006) e também estão presentes em vários tecidos de animais, plantas e microorganismos. De acordo com o mecanismo de catálise, similaridade na seqüência de aminoácidos e análise dos resíduos de aminoácidos posicionados em torno do sítio ativo da molécula, as proteases são classificadas em classes (ou grupos), das quais as principais são: serinoproteases, cisteinoproteases, asparticoproteases e metaloproteases (Powers, 2002; Hedstrom, 2002). 
As cisteinoproteases, presentes em todos os organismos vivos, possuem um resíduo de Cys no sítio ativo e são representadas por proteínas com massas moleculares em torno de 21-30 kDa (Barret \& Rawlings, 2001). Elas mostram maior atividade hidrolítica em pH 4,0-6,5. Dentre as cisteinoproteases estudadas, destaca-se família da papaína por ser a mais bem estudada. A papaína é caracterizada por uma estrutura de dois domínios, no qual o sítio ativo (bolsão catalítico), onde o substrato é ligado, está localizado entre os dois domínios. Os resíduos catalíticos da papaína são a Cys25 e a His159, que são evolutivamente preservadas em todas as cisteinoproteases (Grzonka, 2001).

As asparticoproteases, assim nomeadas devido à presença de resíduos de Asp no sítio ativo, são enzimas cujo pH ótimo se encontra na faixa ácida (Cooper, 2002). Elas estão divididas em 14 famílias amplamente distribuídas entre vertebrados, leveduras, parasitas, vírus, fungos e plantas. Em geral, as asparticoproteases de plantas compartilham alta similaridade seqüencial no N e C-terminal (mais de $60 \%$ de identidade). Em todas as asparticoproteases da família A1, os dois motivos catalíticos são Asp-Thr-Gly (DTG) e Asp-Ser-Gly (DSG) (Simões \& Faro, 2004).

As metaloproteases representam um grande grupo de hidrolases que se caracterizam pela necessidade de um íon metálico para a sua atividade, sendo que a maioria delas é dependente de $\mathrm{Zn}^{2+}$, mas também há representantes que requerem $\mathrm{Ca}^{2+}$ ou $\mathrm{Mn}^{2+}$ (DeClerk, 2000). A carboxipeptidades A é uma representante deste grupo, cujo sítio catalítico é formado por His, Glu e His.

As serinoproteases representam o grupo das enzimas proteolíticas mais bem estudado e caracterizado (Hedstrom, 2002; Gettins, 2002). Por ser um tópico relacionado com o assunto desenvolvido neste trabalho, esta classe será apresentada com mais detalhes no subcapítulo seguinte. 


\section{1.1 - Serinoproteases}

As enzimas proteolíticas conhecidas como serinoproteases são assim nomeadas pela presença do resíduo nucleofílico de Ser no sítio ativo. O sítio ativo é formado por uma “tríade catalítica” representada pelos resíduos de Ser195, His57 e Asp102 (a numeração é baseada na posição dos resíduos na quimotripsina). Entretanto, recentemente foram descritas serinoproteases com novas tríades catalíticas e até díades, incluindo Ser-His-Glu, Ser-Lys/His, His-Ser-His (Hedstrom, 2002).

Quase um terço de todas as proteases podem ser classificadas como serinoproteases (Gettins, 2002). Algumas já bem estudadas, por exemplo, a tripsina, a quimotripsina e a elastase, mostram ter evoluído de um ancestral comum, por apresentarem semelhanças na estrutura e mecanismos de ação. Estes três enzimas mostram diferentes especificidades pelas cadeias laterais que serão atacadas na ligação peptídica a ser clivada. A quimotripsina requer um resíduo hidrofóbico no lado carboxílico da ligação a ser clivada; já a tripsina requer um resíduo carregado positivamente (Lys ou Arg); enquanto que a elastase, um resíduo neutro e pequeno (Voet \& Voet, 2000).

As massas moleculares das serinoproteases variam de 19 a $110 \mathrm{kDa}$, mas a maioria possui massa entre 60 e $80 \mathrm{kDa}$. Em geral, a atividade destas enzimas é otimizada em $\mathrm{pH}$ alcalino (de 7,0 a 11,0 ) e em temperaturas de $20-50^{\circ} \mathrm{C}$. As principais enzimas representantes do grupo das serinoproteases são: tripsina, quimotripsina, elastase, calicreína pancreática, trombina e subtilisina (Antão \& Malcata, 2005).

A base do mecanismo de ação das serinoproteases envolve a transferência de um grupo acil de um substrato para um grupo funcional da enzima (característica que 
é compartilhada com outras transferases). Os dois passos básicos de catálise por este grupo de enzimas, também mostrado na Figura 1, incluem (a) a formação de um éster entre o átomo de oxigênio e o grupo acil do substrato, produzindo um intermediário tetraédrico e liberando a parte amino do substrato; e (b) o ataque da água ao intermediário acil-enzima, que promove a quebra e liberação o produto acídico e retomando a forma original da enzima. (Antão \& Malcata, 2005).

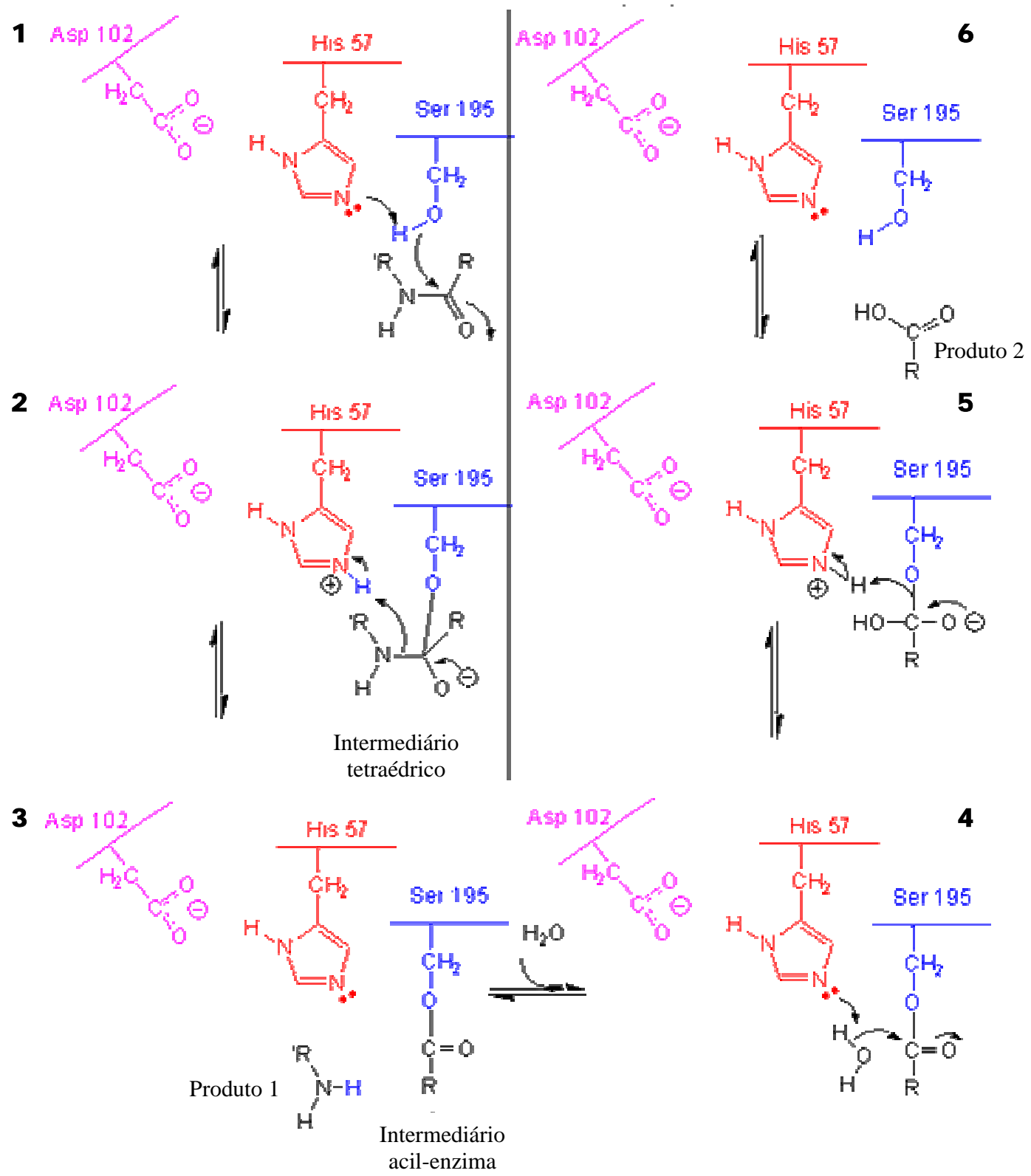

Figura 1 - Mecanismo da reação catalisada por serinoproteases. Clivagem hidrolítica de cadeia polipeptídica. 
Serinoproteases estão envolvidas em muitos processos fisiológicos como processos inflamatórios, digestivos, proliferação e diferenciação celular, reabsorção óssea e coagulação sangüínea (Powers, 2002). As serinoproteases da família da tripsina são decididamente as enzimas proteolíticas mais versáteis e as mais amplamente estudadas. No sistema cardiovascular, a importância destas enzimas na coagulação sangüínea, ativação de plaquetas e trombose é bem estabelecida (Wu et al, 2005).

\section{2 - Inibidores de proteases}

Uma proteólise descontrolada, desregulada e indesejada pode conduzir a muitos estados de enfermidade, incluindo enfisema, derrame cerebral, câncer, mal de Alzheimer, inflamação e artrite (Powers, 2002). Além disso, a maioria das proteases é potencialmente prejudicial ao seu ambiente natural (Bode \& Huber, 2000) e, para limitar esses danos, tais moléculas devem ser estritamente controladas.

O controle da atividade proteolítica se dá: (1) pela biosíntese destas enzimas sob a forma de precursores inativos, denominados zimogênios, cuja ativação dependerá de uma proteólise ou remoção de aminoácidos na porção N-terminal da molécula precursora; (2) pela regulação da expressão/secreção; (3) pelo bloqueio, total ou diminuição da atividade catalítica sobre um determinado substrato através de moléculas denominadas inibidores, que formam um complexo estequiométrico com a protease. Desta forma, os inibidores de proteases têm um potencial considerável para intervenção terapêutica numa variedade de moléstias (Powers, 2002). Adicionalmente a sua função de regulação das atividades proteolíticas, os inibidores 
de proteases são importantes na proteção de fluidos e tecidos, tais como soro sangüíneo, células pancreáticas e tecidos de reserva de plantas, contra sua degradação por proteólise (Ryan, 1990).

Os inibidores naturais ou protéicos são encontrados em todos os seres vivos, distribuindo-se em microorganismos, plantas e animais. Em plantas, o possível papel dos inibidores de proteases na sua proteção só foi investigado no início de 1947, quando foi observado que larvas de certos insetos não se desenvolviam em produtos de sementes de soja e, mais tarde, que inibidores de tripsina de soja mostraram toxicidade a outros insetos (Lawrence \& Koudal, 2000).

O alto teor dos inibidores de proteases nas sementes de muitas espécies de plantas tem despertado o interesse quanto a sua função fisiológica, sugerindo atuação no armazenamento de nutrientes, ação protetora contra o ataque de animais predadores, insetos (Carlini, 2002), e microorganismos. Muitas plantas são induzidas a acumularem proteínas durante uma resposta de defesa, em especial certas famílias de proteínas, como as hidrolases e os inibidores de protease (Shewry \& Lucas, 1997).

Além de atuarem no mecanismo de defesa contra fungos, insetos e outros parasitas (Breiteneder \& Radauer, 2004) e como proteínas de reserva, os inibidores podem ainda desempenhar funções fisiológicas no controle das enzimas proteolíticas durante a dormência e a germinação, prevenindo a hidrólise prematura do material de reserva, controlando assim, a mobilização de proteínas durante estes períodos (Bronse, 1990; Broadway, 1995).

Recentemente, inibidores de proteases têm sido empregados como novas drogas na terapia anti-retroviral altamente ativa, o que tem aumentado a expectativa de vida de pacientes HIV positivos (Asztalos et al, 2006; Yeni, 2006). 
Basicamente os inibidores de proteases são categorizados de acordo com a protease que eles inibem: serino, cisteíno, aspártico ou metaloproteases. Os grupos mais conhecidos de inibidores de enzimas de sementes são aqueles que interferem na atividade de serinoproteases como a tripsina, quimotripsina e subtilisina.

\section{2.1 - Inibidores de serinoproteases}

Os membros da classe de inibidores de serinoproteases têm sido mais estudados do que qualquer outra classe de inibidores de proteases (Ryan, 1990).

As proteínas desta classe apresentam uma inibição estritamente competitiva e de estequiometria 1:1 na formação do complexo enzima-inibidor. De forma contrária aos complexos de enzima-substrato ou enzima-produto que se dissociam muito rapidamente, o complexo enzima-inibidor é altamente estável, com valores de $\mathrm{K}_{\mathrm{A}}$ entre $10^{8}-10^{13} \mathrm{M}^{-1}$ (Richardson, 1991).

Muitos compostos inativam as serinoproteases pela formação de um intermediário acil-enzima estável. O mecanismo de ação de muitas classes de inibidores de proteases é formar um tetraedro estável que imita o complexo intermediário tetraédrico da reação das enzimas (Hedstrom, 2002). O oxiânion do intermediário tetraédrico é frequentemente estabilizado pela interação com muitas pontes de hidrogênio.

Inibidores de serinoproteases são distribuídos largamente entre animais, plantas e microorganismos (Zhao et al, 2005). Baseado em sua seqüência primária, estrutura tridimensional e mecanismo de inibição, eles são classificados em pelo menos 18 famílias (Zhao et al, 2005), que estão compiladas na Tabela 1 (Laskowski Jr \& 
Qasim, 2000). Em plantas, a distinção entre as famílias foi realizada com base na determinação da seqüência primária destes inibidores, ou seja, com base na identidade da estrutura primária, na localização das pontes dissulfeto e na posição dos sítios reativos (Richardson, 1991).

Dentre as famílias de inibidores de serinoproteases de plantas mais representativas estão: Bowman-Birk, Kunitz, Batata I, Batata II e Abóbora.

\begin{tabular}{||l||l||}
\hline \hline FAMÍLIA & OCORRÊNCIA \\
\hline \hline Antistasin & Animais \\
\hline Arrowed & Plantas \\
\hline Ascaris & Animais \\
\hline Bowman-Birk & Plantas \\
\hline Chelonianin & Animais \\
\hline Ecotin & Microorganismos \\
\hline Grasshopper & Animais \\
\hline Kazal & Animais \\
\hline Kunitz (BPTI) & Animais \\
\hline Kunitz (STI) & Plantas \\
\hline Marinostatin & Microorganismos \\
\hline Batata I & Plantas \\
\hline Batata II & Plantas \\
\hline Rapeseed & Plantas \\
\hline Silkworm & Animais \\
\hline Fungal protease inhibitor F & Plantas \\
\hline SSI & \\
\hline Abóbora & \\
\hline \hline
\end{tabular}

Tabela 1 - As famílias de proteínas inibidoras de serinoproteases. Modificado a partir de Laskowski Jr \& Qasim, 2000. 


\section{2.1.1 - Família Bowman-Birk}

Os inibidores de protease do tipo Bowman-Birk foram os primeiros inibidores enzimáticos de sementes a ter a seqüência de aminoácidos determinada, isolados da fava de Phaseolus lunatus (Tan \& Stevens, 1971). Eles são caracterizados por possuírem massa molecular relativamente pequena (por volta de 8 - $9 \mathrm{kDa}$ ) e um alto conteúdo de resíduos de Cys formando 7 pontes de dissulfeto.

Os inibidores dessa família são geralmente double-headed, ou seja, são capazes de formar complexos de estequiometria 1:1 com diferentes proteases (comumente tripsina e quimotripsina e raramente elastase) em sítios reativos independentes. (Birk, 1985; Richardson, 1991).

\section{2.1.2 - Família Batata I e Batata II}

Os inibidores pertencentes à família Batata I apresentam seqüências primárias com alta identidade com o inibidor de quimotripsina I isolado de tubérculos de batatas. Eles são proteínas oligoméricas com massa molecular de 41 kDa, apresentando cinco monômeros por volta de 8 kDa cada e uma ponte dissulfeto.

Todos os inibidores isolados das plantas desta família mostram uma surpreendente identidade estrutural (aproximadamente 36\%) com um inibidor de animal inferior, o parasita Hirudo medicinalis (Richardson, 1991).

A família de inibidores Batata II se diferencia por serem maiores e apresentarem elevado número de pontes dissulfeto (Laskowski \& Kato, 1980) além de apresentarem um grau de identidade seqüencial limitado com as regiões Nterminal dos inibidores de carboxipeptidase da batata e tomate. 


\section{2.1.3 - Família Abóbora}

As proteínas desta família representam os menores inibidores de planta de serinoproteases conhecidos. Estes inibidores apresentam valores de inibição muito potentes, com $\mathrm{K}_{\mathrm{A}}$ da ordem de $10^{11} \mathrm{M}^{-1}$, um dos valores mais altos para inibidores de tripsina (Richardson, 1991). Estes inibidores são constituídos de aproximadamente 29 a 32 resíduos, são interligados por três pontes dissulfeto e contem Arg-Ile ou LysIle no sítio reativo.

\section{2.1.4 - Família Kunitz}

Os inibidores do tipo Kunitz contêm de 170 a 200 resíduos de aminoácidos, o que corresponde a uma massa molecular de aproximadamente $21-22 \mathrm{kDa}$, sendo formados por uma ou duas cadeias polipeptídicas e, em geral, apresentam quatro resíduos de cisteína, que formam duas pontes dissulfeto (Cys39-Cys85 e Cys136Cys145, de acordo com a seqüência do inibidor de tripsina de soja) (Oliva, 2000; Carlíni, 2002).

Inibidores desta família apresentam identidade seqüencial com o inibidor de protease de soja (STI), cuja determinação da estrutura primária completa revelou ser composto por uma única cadeia com massa molecular de $21 \mathrm{kDa}$, contendo quatro cisteínas que mantém duas pontes dissulfeto. A análise da estrutura cristalina deste inibidor revelou ausência de hélices- $\alpha$, sendo formado principalmente por folhas- $\beta$ e estruturas desordenadas. A estrutura secundária de outros inibidores tipo Kunitz, tal como o inibidor de quimotripsina isolado de Schizolobium parahyba, também é formada principalmente de folhas- $\beta$ e estruturas desordenadas (Teles et al, 2004). 
Enquanto a maioria destes inibidores possui cadeia molecular única, outros, isolados de sementes da subfamília Mimosoideae (do gênero Acácia, Adenanthera, Albizzia, Enterolobium e Leucaena), são compostos por uma cadeia longa (designada A ou $\alpha$ ) de aproximadamente $16 \mathrm{kDa}$ e uma cadeia pequena (designada $\mathrm{B}$ ou $\beta$ ) de aproximadamente $5 \mathrm{kDa}$ unidas por uma ponte dissulfeto.

A família de inibidores de proteases do tipo Kunitz é uma das famílias mais importantes de inibidores de proteases. Ela compreende proteínas de plantas com atividade inibitória sobre várias enzimas proteolíticas, como as serinoproteases (tripsina, quimotripsina e subtilisina), cisteinoproteases e asparticoproteases.

Os inibidores de serinoproteases tipo Kunitz são encontrados em todas as partes das plantas, mas uma grande quantidade está localizada em sementes, principalmente em três subfamílias de Leguminosae, são elas: Mimosoideae, Caesalpinioideae e Papilionoideae (Richardson, 1991).

\section{2.2 - Inibidores de proteases na família Leguminosae}

A família Leguminosae (Fabaceae) é extraordinariamente rica em plantas úteis e de grande importância para o homem. Boa parte pertence, originalmente, à flora brasileira. A subfamília Mimosoideae é composta por árvores e arbustos, raramente ervas (Schultz, 1985).

As sementes de leguminosas contêm grandes quantidades de proteínas importantes para os mais diversos processos biológicos. Os inibidores de proteases desta família são os mais bem estudados, pois tal família é reconhecida como excelente fonte destes compostos (Richardson, 1991). 
Recentes estudos na literatura citam diversos trabalhos sobre inibidores extraídos e purificados das sementes de leguminosas, como os de Schizolobium parahyba (Teles et al, 2004), os de Archidendron ellipticum (Bhattcharyya et al, 2006) e de Pithecellobium dulce (Vargas et al, 2004) pois o interesse na busca por novos inibidores de proteases está centrado no amplo espectro de atuação de tais compostos em diversos processos fisiológicos, tais como, inflamação e hemorragia (Oliva et al, 2000), câncer (Xie et al, 2005), AIDS (Asztalos et al, 2006; Yeni, 2006), engenharia genética de plantas (Haq et al, 2004).

\section{3 - O gênero Acacia}

Das espécies que compõe o gênero Acacia, foram relatadas diversas atividades biológicas, tais como: atividade antibacterial em A. aroma (Arias et al, 2004), atividade citotóxica em A. pennatula (Popoca et al, 1998), inibição do crescimento de células tumorais in vitro em A. confusa (Hung et al, 1993), atividade hemaglutinante pela presença de uma lectina em A. constricta (Guzmán-Partida et al, 2004) e inibição de enzimas proteolíticas em diversas espécies, dentre as quais foram isolados inibidores de proteases de A. elata, denominado AeTI (Kortt \& Jermyn, 1981), A. sieberana (Joubert, 1983) e A.confusa, denominado AcTI (Lin et al, 1991).

O AcTI é um inibidor de proteases do tipo Kunitz formado por 2 cadeias, com massa molecular por volta de 21 kDa, composto de 175 resíduos de aminoácidos, incluindo 4 resíduos de Cys (Hung et al, 1994). O sítio reativo de AcTI foi deduzido a partir da determinação completa da sua seqüência de aminoácidos, sendo 
localizado na região Lys64-Ile65. No extrato de A.confusa não foram encontrados inibidores da família Bowman-Birk (Wu \& Lin, 1993).

\section{3.1 - A espécie Acacia plumosa Lowe}

A Acacia plumosa é uma planta nativa do Brasil pertencente à família Leguminosae e subfamília Mimosoideae. Seu nome científico indica a forma da sua inflorescência (forma de pluma) como mostra a Figura 2. Popularmente, a planta é conhecida como arranha-gato por se tratar de uma planta perene, formando maciços impenetráveis, devido a sua intensa ramificação e grande número de espinhos recurvados à semelhança de unhas afiadas. Pode atingir até 3-4 m de altura (Lorenzi, 2000). Outro nome popular, menos conhecido, que também se dá à A.plumosa é Nhapindá.

A. plumosa é muito freqüente em solos férteis e úmidos do Centro-Sul do país, onde é uma das principais infestantes de pastagens. Ocorre também em baixadas úmidas, beira de cursos d’água e lagoas. Uma única planta pode cobrir uma área de $100 \mathrm{~m}^{2}$. Floresce durante os meses de novembro a janeiro, com frutificação de fevereiro a abril.

As vagens da planta contêm por volta de 12 sementes e medem aproximadamente $8 \mathrm{~cm}$. As sementes apresentam um tegumento de coloração marrom e possuem em média 8,5 mm de comprimento, 5,5 mm de largura e 1,5 mm de espessura, apresentando uma massa média de $45 \mathrm{mg}$. 


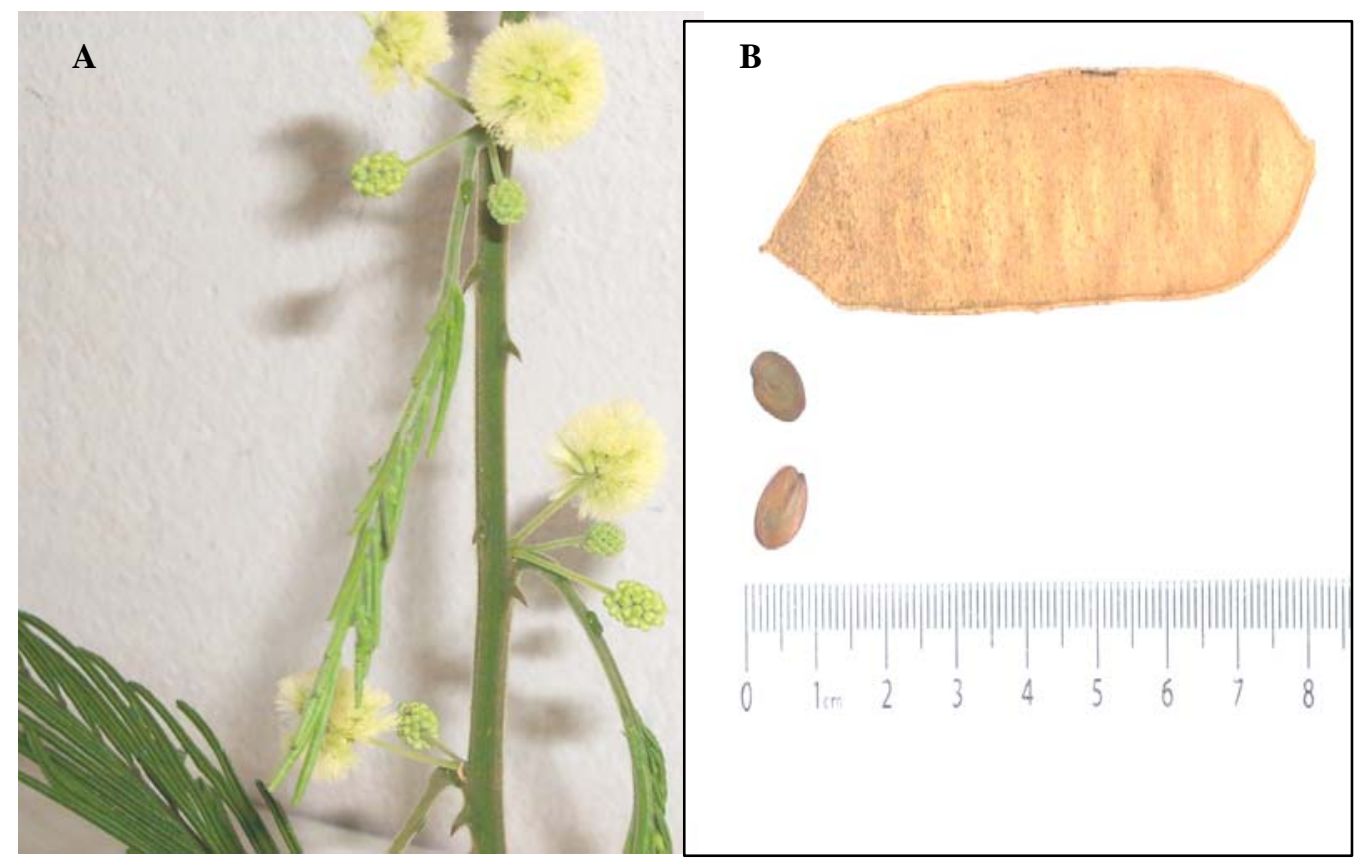

Figura 2 - Ilustração da espécie Acacia plumosa Lowe. (A) parte do caule espinhoso, folhas e as inflorescências amarelas em forma de pluma; (B) uma vagem e sementes da planta.

O arranha-gato é popularmente utilizado em casos de artrites, cálculo renal e gastrite. A planta é conhecida como um famoso antireumático, por amenizar dores nas costas e nas pernas e por ser usada até contra doenças venéreas. Acredita-se que sua principal ação seja a de estimular as células de defesa do organismo para aumentar a resistência à infecções de quaisquer origens, conferir um maior poder de cicatrização e atividade antiviral.

Não existem, na literatura, trabalhos que explorem a purificação e a caracterização de proteínas ou outros compostos presentes no arranha-gato. Inexistentes, também, são os trabalhos que descrevam suas potenciais atividades biológicas, a fim de estabelecer uma relação entre o uso popular do arranha-gato com o seu potencial uso fármaco-dinâmico. 


\section{4 - Objetivos}

O propósito deste trabalho foi o isolamento, a purificação e a elucidação de propriedades físico-químicas e estruturais dos inibidores de proteases presentes nas sementes da leguminosa Acacia plumosa. Neste intuito, as seguintes etapas foram desenvolvidas:

- Investigação da presença de inibidores no extrato salino das sementes de Acacia plumosa por meio de ensaios de inibição da coagulação sanguínea e de inibição da atividade da tripsina;

- Isolamento e purificação destes inibidores por meio de técnicas cromatográficas;

- Estudos estruturais com os inibidores com o uso das espectroscopias de CD e fluorescência, avaliando as possíveis mudanças conformacionais sofridas em função do pH e da temperatura;

- Estudo das propriedades físico-químicas, como pI, massa molecular, e determinação das constantes de associação/dissociação destes inibidores com enzimas proteolíticas;

- Determinação das atividades biológicas destes inibidores frente a fungos fitopatogênicos. 


\section{II - MATERIAIS E MÉTODOS}

\section{1 - MATERIAIS}

\section{1.1 - Materiais e Equipamentos utilizados}

- Sementes de Acacia plumosa (Família: Leguminosae; SubFamília: Mimosoideae) coletadas no bairro Jardim Bandeirantes da cidade de São Carlos, no estado de São Paulo;

- Vidrarias;

- $\quad$ Almofariz e pistilo;

- Balanças analíticas e convencionais;

- $\quad$ pHmetro;

- $\quad$ Plasma sangüíneo (obtido de doadores do Grupo de Biofísica do IFSC).

- $\quad$ Centrífuga refrigerada comum (modelo 5B e RC5C plus, Sorval) e centrífuga de bancada (modelo 5414D Eppendorf e 206-R excelsa baby-II, Fanem);

- Tubos de vidro e tubos de polietileno;

- $\quad$ Centriprep e Centricon (3 kDa; Amicon);

- $\quad$ Cela de ultrafiltração (Amicon);

- $\quad$ Membranas e sacos de diálise YM (3 kDa; Amicon);

- Banho-maria;

- $\quad$ Termômetro; 
- $\quad$ Geladeira e freezer $\left(-20^{\circ} \mathrm{C}\right)$ convencionais;

- $\quad$ Espectrofotômetro mod U-2001 (Hitachi);

- $\quad$ Espectrofotômetro mod U-2801 (Hitachi);

- $\quad$ Sistema para eletroforese (Bio-rad);

- $\quad$ Sistema para cromatografia de alta e baixa pressão ÄKTA purifier system (Amersham Pharmacia Biotech);

- Bombas de vácuo;

- Espectropolarímetro modelo J-715 (Jasco) acoplado com banho TC-100 (Jasco) para experimentos de desnaturação térmica;

- $\quad$ Espectrofluorímetro ISS K2 (ISS Fluorescence, Analytical and Biomedical Instruments);

- $\quad$ Cubetas cilíndricas de quartzo (caminho óptico $1 \mathrm{~mm}$ );

- $\quad$ Cubetas retangulares de quartzo (caminho óptico $1 \mathrm{~mm}$ );

- $\quad$ BIAcore X (BIACORE AB, Upsala, Suécia) e sensorchip CM5;

- Seqüenciador automatizado de proteínas modelo PPSQ-23A Shimadzu (Kyoto, Japan);

- $\quad$ Espectrômetro de massa modelo Quattro II Eletrospray Triple Quadrupole MS (Micromass, Manchester, UK);

- $\quad$ Sistema para cromatografia de alta pressão HPLC (Bio-rad, Califórnia - EUA);

- $\quad$ Sistema centrífugo/liofilizador Savant (Speedvac);

- $\quad$ Microplacas de 96 poços;

- $\quad$ Placas de Petri; 


\section{1.2 - Reagentes, resinas e soluções}

Os reagentes químicos utilizados foram de grau P.A. ou equivalentes. São eles: acetonitrila, TFA, EDTA, guanidina-HCl, Tris-HCl, DTT, $\beta$-mercaptoetanol, 4-vinilpiridina, SDS, glicina, $\mathrm{NaCl}, \mathrm{MgCl}_{2}, \mathrm{CuSO}_{4}, \mathrm{Na}_{2} \mathrm{CO}_{3}$, acrilamida, $\mathrm{NaHPO}_{4}$, $\mathrm{KH}_{2} \mathrm{PO}_{4}, \mathrm{NaOH}, \mathrm{HCl}$, ácido acético, acetato de sódio, água milliQ, etanol, reagente de Folin-Ciocalteau, tripsina (Sigma), tripsina (Promega), carboxipeptidase A pancreática bovina (35 kDa), quimotripsina, substratos (BAPNA e hippuril-Phe), albumina sérica bovina (BSA - $66 \mathrm{kDa}$ ), ovalbumina (OVA - $45 \mathrm{kDa}$ ), anidrase carbônica (ACB - $30 \mathrm{kDa}$ ), inibidor de tripsina de soja (ITS - 20,1 kDa), citocromo $\mathrm{C}$ (cit C - 12,4 kDa), riboflavina (ribof. - $375 \mathrm{Da}$ ), fragmentos de mioglobina de massa molecular 16,95; 14,44; 10,6; 8,16; 6,21; e 2,51 kDa (Sigma Chemical Co., EUA), Comassie Brilliant Blue G-250 e R-250.

As resinas cromatográficas utilizadas foram: Superdex 75 HR 10/30 (Pharmacia LKB Biotechnology, Uppsala, Suécia), Mono-S HR 5/5 (Pharmacia LKB Biotechnology, Uppsala, Suécia), coluna de fase reversa $C_{18}(250$ x $4.6 \mathrm{~mm}$, partícula $6 \mu \mathrm{m}$ YMC Inc, Waters, Alemanha).

As soluções utilizadas na purificação dos inibidores foram: tampão fosfato salino (phosphate buffer saline, PBS) que é constituído de fosfato de sódio dibásico 0,06 M e NaCl 0,15 M, pH 7,4 ajustado com fosfato de potássio monobásico 0,15 M; tampão acetato de sódio $50 \mathrm{mM}$ pH 5,0; e tampão acetato de sódio $50 \mathrm{mM} \mathrm{pH} \mathrm{5,0}$ com $\mathrm{NaCl} 0,5 \mathrm{M}$.

Para a redução e alquilação dos inibidores foram utilizadas as seguintes soluções: Tampão Tris/HCl 0,25 M pH 8,0 acrescido de EDTA 2 mM, guanidina$\mathrm{HCl} 6 \mathrm{M}$ e $\beta$-mercaptoetanol, 4-vinil-piridina (Sigma-Aldrich) e ácido acético glacial 
10\%. A redução e a alquilação também foi promovida com as seguintes soluções: $\mathrm{NH}_{4} \mathrm{HCO}_{3}$ 0,1M com 50\% ACN e DTT (45 mM), Iodoacetamida $100 \mathrm{mM}$ e ácido fórmico.

\section{2 - MÉTODOS}

\section{2.1 - Obtenção do extrato bruto}

As vagens de Acacia plumosa, coletadas na cidade de São Carlos, foram identificadas no Grupo de Biofísica do Instituto de Física de São Carlos. As sementes foram retiradas das vagens e selecionadas. Os cotilédones foram separados do tegumento (casca), fragmentados e macerados em almofariz até a obtenção de um pó bem fino. A farinha de A. plumosa foi submetida à extração protéica adicionando-se uma solução salina tamponada (PBS) $\mathrm{pH} 7,4$ contendo $0,15 \mathrm{M}$ de $\mathrm{NaCl}$ (numa proporção 1:10, massa/volume). A mistura foi colocada sob agitação branda por 2 horas a $4^{\circ} \mathrm{C}$, seguida por centrifugação (por 30 minutos, $10.000 \mathrm{rpm}, 4^{\circ} \mathrm{C}$ ), sendo o precipitado descartado e o sobrenadante coletado. O sobrenadante foi filtrado em papel filtro e posteriormente dialisados em sacos YM-3 contra PBS (pH 7,4), com trocas regulares de tampão a cada 4 horas, durante 1 dia. Após o término da diálise, o extrato bruto foi então estocado a $-20^{\circ} \mathrm{C}$. O fluxograma da Figura 3 ilustra o protocolo de obtenção do extrato bruto das sementes de A. plumosa. 


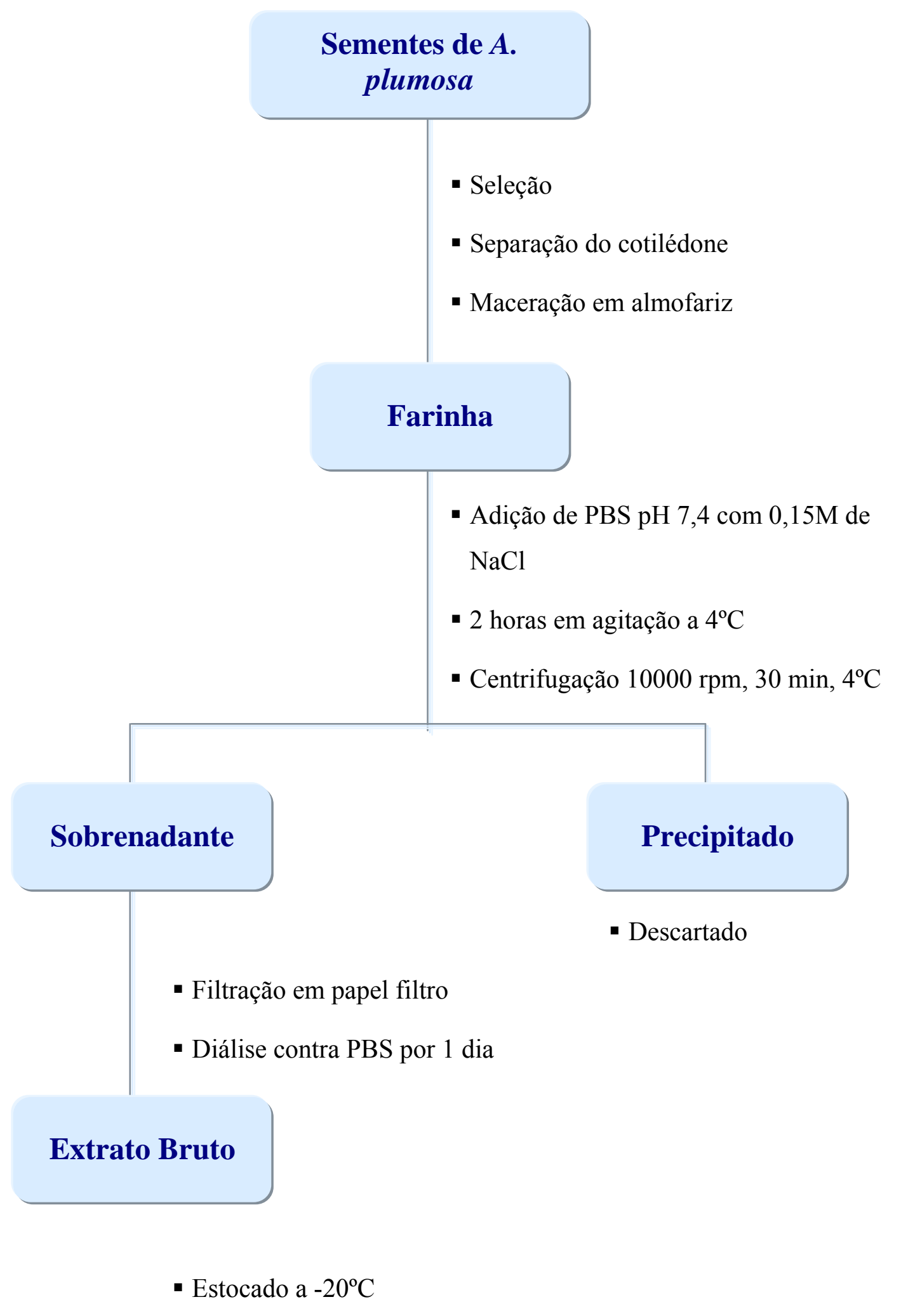

Figura 3 - Obtenção do extrato bruto das sementes de Acacia plumosa. Fluxograma das etapas para a obtenção do EB das sementes de A. plumosa. 


\section{2.2 - Purificação do Inibidor}

\section{2.2.1 - Cromatografia de Exclusão Molecular}

Alíquotas do EB de A. plumosa foram submetidas à cromatografia de exclusão molecular em coluna Superdex 75, usando o sistema AKTA purifier ${ }^{\mathrm{TM}}$. A coluna foi equilibrada e eluída com PBS pH 7,4. A eluição ocorreu num fluxo de 0,5 mL/min e foi monitorada pela absorbância em $280 \mathrm{~nm}$. A coluna foi previamente calibrada com as seguintes proteínas (padrões de massa molecular): albumina sérica bovina (66 $\mathrm{kDa})$, anidrase carbônica (30 kDa), citocromo C (12,4 kDa) e riboflavina (375 Da). As frações eluídas da filtração molecular foram coletadas, dialisadas e filtradas em centriprep-3 para serem testadas quanto à capacidade de inibição da coagulação sanguínea e inibição da atividade da tripsina.

\section{2.2.2 - Cromatografia de Troca Iônica}

A fração que apresentou atividade anticoagulante in vitro proveniente da exclusão molecular, teve o tampão trocado para Acetato de Sódio $50 \mathrm{mM} \mathrm{pH} \mathrm{5,0} \mathrm{em}$ cela de ultrafiltração (Amicon) contra membrana de $3 \mathrm{kDa}$. Esta fração foi então submetida à cromatografia de troca iônica em coluna Mono-S, previamente equilibrada com o tampão Acetato de Sódio $50 \mathrm{mM}$ pH 5,0 e eluída no mesmo tampão contendo $0,5 \mathrm{M}$ de $\mathrm{NaCl}$, num gradiente de 0 a $100 \%$ de $\mathrm{NaCl}$ durante 50 minutos. A eluição foi monitorada em $280 \mathrm{~nm}$ e ocorreu num fluxo de $1 \mathrm{~mL} / \mathrm{min}$, sendo coletadas frações de $0,5 \mathrm{~mL}$. 
Todas as frações que correspondiam a um pico de absorbância em $280 \mathrm{~nm}$ desta etapa cromatográfica foram dialoconcentradas e empregadas em ensaios de inibição da coagulação sanguínea e de inibição da atividade da tripsina. As frações que apresentaram tais atividades foram posteriormente estudadas por SDS-PAGE, ensaios espectroscópicos, determinação de massa molecular e seqüenciamento NTerminal.

\section{2.2.3 - Eletroforese em Gel de Poliacrilamida}

As amostras derivadas de cada procedimento cromatográfico tiveram suas massas moleculares estimadas e foram avaliadas quanto à homogeneidade por eletroforese em gel de poliacrilamida. A eletroforese foi realizada segundo o método de Tricina (Schagger, 1987), em gel de poliacrilamida 16\%, em condições desnaturantes, utilizando o detergente duodecil sulfato de sódio (SDS), na presença e na ausência do agente redutor $\beta$-mercaptoetanol. As proteínas usadas como padrões de massa molecular alta foram: BSA (66 kDa), ovalbumina (OVA - $45 \mathrm{kDa}), \mathrm{ACB}$ (30 kDa), inibidor de tripsina de soja (ITS - 20,1 kDa) e Cit C (12,4 kDa). Como padrões de massa molecular baixa foram utilizados fragmentos de mioglobina (Sigma Chemical Co, EUA).

O tampão Tris- $\mathrm{HCl} 25 \mathrm{mM}$ contendo glicina $0,18 \mathrm{M}$ e SDS $0,1 \%(\mathrm{~m} / \mathrm{v})$ foi utilizado como tampão de corrida. A eletroforese foi efetuada sob uma tensão de 30 V para a separação das amostras durante a migração no gel de empilhamento, e posteriormente teve sua tensão ajustada para $100 \mathrm{~V}$ para a migração das amostras no gel de resolução. Após o término da eletroforese (que durou por volta de 4 horas), a 
presença das bandas protéicas foi detectada com a imersão dos géis numa solução de corante Comassie Brilliant Blue 250 R, por 15 minutos sob agitação branda. Em seguida, os géis foram descorados com ácido acético 7\%.

\section{2.2.4 - Cromatografia de Fase Reversa}

As frações provenientes da cromatografia de troca iônica que apresentaram atividade de inibição da coagulação sanguínea foram submetidas à cromatografia de fase reversa em coluna $\mathrm{C}_{18}$ ao um sistema HPLC. A coluna foi previamente equilibrada com TFA $0,1 \%$ em $\mathrm{H}_{2} \mathrm{O}$ e eluída num gradiente 0 a $100 \%$ do solvente TFA $0,1 \%$ em $90 \%$ de acetonitrila, sob um fluxo de $1 \mathrm{~mL} / \mathrm{min}$, durante 60 minutos. A eluição foi monitorada em $220 \mathrm{~nm}$.

Esta etapa cromatográfica foi também utilizada para separar as cadeias dos inibidores após serem submetidos às reações de redução e de alquilação.

\section{2.2.5 - Determinação de proteínas totais do extrato bruto e}

\section{quantificação dos inibidores}

A determinação de proteínas totais do Extrato Bruto (EB) de A. plumosa foi realizada pelo método de Lowry (Lowry et al, 1951), cuja reação colorimétrica envolve a oxidação dos aminoácidos aromáticos da proteína com o reagente de fenol; a oxidação é catalisada por cobre em meio alcalino. 
Uma curva padrão foi preparada utilizando BSA, com concentrações variando de 0 a $100 \mu \mathrm{g} / \mathrm{mL}$. A solução protéica $(1 \mathrm{~mL})$ foi incubada por 10 minutos, em temperatura ambiente, com $5 \mathrm{~mL}$ de uma solução constituída de $\mathrm{CuSO}_{4}$ a $0,5 \%$ (m/v) em citrato de sódio a $1 \%(\mathrm{~m} / \mathrm{v})$ e $50 \mathrm{~mL}$ de solução de $\mathrm{Na}_{2} \mathrm{CO}_{3}$ a $2 \%(\mathrm{~m} / \mathrm{v}) \mathrm{em} \mathrm{NaOH}$ a $0.1 \%$. Após esta incubação, $0,5 \mathrm{~mL}$ do reagente de Folin-Ciocalteua, diluído 1:1 em água, foi adicionado continuando a incubação por mais 30 minutos. A leitura da absorção das amostras empregadas neste ensaio se deu em $750 \mathrm{~nm}$.

A quantificação dos inibidores após purificação foi feita por meio da determinação experimental do coeficiente de extinção molar.

\section{2.3 - Análise físico-química e estrutural das isoformas dos}

inibidores

\section{2.3.1 - Determinação do Ponto Isoelétrico}

A eletroforese de focalização isoelétrica com as amostras que apresentaram atividade anticoagulante e atividade inibitória da tripsina provenientes da cromatografia de exclusão molecular e da cromatografia de troca iônica foi realizada utilizando o sistema PhastSystem (Pharmacia LKB Biotechnology) com o meio de separação PhastGel IEF, na faixa de pH de 3,0 a 9,0. Como padrão foi utilizado o kit comercial com valores de pI de 8,$65 ; 8,45 ; 8,15 ; 7,35 ; 6,85 ; 6,55 ; 5,85 ; 5,2 ; 4,45$ e 3,5 (Amersham Bioscience ${ }^{\mathrm{TM}}$ ). O gel foi corado com Coomasie Blue G - 250 . 


\section{2.3.2 - Formação do complexo enzima-inibidor}

Amostras dos inibidores ApTIA, ApTIB, ApTIC e ApTID foram colocadas em PBS pH 7,4 e posteriormente incubadas por 30 minutos a $37^{\circ} \mathrm{C}$ com tripsina (Sigma) na razão molar 1:3. Após incubação, a mistura foi aplicada numa coluna de gel filtração Superdex 75 e a eluição se deu com PBS, fluxo de $0,5 \mathrm{~mL} / \mathrm{min}$, com o monitoramento da absorbância em $280 \mathrm{~nm}$.

\section{2.3.2.1 - Determinação de $K_{A}$ e $K_{D}$ do complexo}

$\mathrm{O}$ estudo das interações moleculares entre os inibidores e enzimas proteolíticas foi realizado no instrumento BIAcore $X^{\circledR}$ que utiliza a técnica de Ressonância Plasmônica de Superfície (SPR), técnica óptica que mede mudanças no índice de refração que ocorrem na interface da camada sensor-fluido (Wilson, 2002).

Quando um feixe de luz passa de um material com maior índice de refração (por exemplo, o vidro) para um material com menor índice de refração (por exemplo, a água), haverá uma parcela da luz que será refletida na interface dos dois meios. Quando o ângulo de incidência do feixe de luz na interface dos meios $(\theta)$ for maior que um ângulo crítico, então a luz será totalmente refletida (ocorrerá reflexão interna total). Se a superfície do vidro for coberta com um filme fino de um metal nobre (por exemplo, o ouro), esta reflexão não será total. Parte da luz será "perdida" para o filme metálico. Deve haver então, um segundo ângulo maior que o ângulo crítico em que essa perda é maior, e em que a intensidade da luz refletida alcança um mínimo ou um "dip". Este ângulo é chamado de ângulo de ressonância plasmônica de 
superfície $\left(\theta_{\mathrm{SPR}}\right)$. Ele é uma conseqüência da oscilação de elétrons que se propagam (ou plasmas) na superfície do filme de metal.

Um sensorchip é criado pela aplicação de uma fina camada de ouro (por volta de $50 \mathrm{~nm}$ ) numa superfície de vidro. Sobre a camada de ouro, nos tipos mais comuns de sensorchip, são ligados grupos de carboximetil-dextrana, resultando numa camada de interação de aproximadamente $100 \mathrm{~nm}$ de espessura.

Uma das moléculas do complexo a ser investigado, o ligante, é imobilizada sobre o sensorchip a fim de criar uma superfície de reconhecimento específico. A imobilização do ligante se dá através da ativação dos grupos carboxil-dextrana por reagentes apropriados, seguida pela ligação covalente do ligante com a camada de interação do sensorchip. Uma solução da outra molécula que forma o complexo, chamada de analito, passa sobre este sensorchip e interage com o ligante a fim de formar um complexo. A resposta desta interação, devido a formação do complexo que resulta no acúmulo gradativo de massa na superfície do sensorchip é a mudança do índice de refração do meio, que resulta na mudança no ângulo $\theta_{\mathrm{SPR}}$. Este ângulo é medido em unidades de ressonância (RU), onde 1000 RU correspondem a uma variação angular de aproximadamente $0,1^{\circ}$ (Biacore AB, 2002).

Se um dado analito não interage com o ligante, a mudança no ângulo SPR na cela onde o ligante está imobilizado e na cela de referência (constituída apenas de grupos carboximetil-dextrana) são iguais, o que resulta numa resposta em RU nula quando da subtração dos dois valores, indicando que não ocorreu ligação.

Para muitas proteínas, a ligação de cerca de $1 \mathrm{ng} / \mathrm{mm}^{2}$ de proteína na superfície de dextrana é necessária para gerar um sinal de 1000 RU. No entanto, a relação exata entre RU e nanogramas de material ligado varia com o índice de refração da molécula. 


\section{2.3.2.1 - Ensaio com tripsina}

A imobilização da tripsina (Promega) foi feita pela técnica do acoplamento amina, conforme as recomendações do fabricante (Biacore): utiliza-se uma mistura equimolar dos reagentes NHS e EDC para a ativação dos grupos carboximetildextrana, seguido de etanolamina-HCl, num sensorchip CM5. A imobilização se deu utilizando $20 \mu \mathrm{L}$ da enzima $(1,5 \mu \mathrm{M})$, em Acetato de Sódio $10 \mathrm{mM}, \mathrm{pH}$ 5,0, seguida pela lavagem com tampão HBS-EP, que é composto de $0.01 \mathrm{M}$ HEPES pH 7,4, 0,15 $\mathrm{M} \mathrm{NaCl}, 3$ mM EDTA contendo $0.005 \%$ do surfactante $\mathrm{P}_{2} \mathrm{O}$, à temperatura ambiente. Os níveis finais da imobilização foram por volta de 1480 RU.

Os ensaios de ligação foram realizados sob um fluxo de $30 \mu \mathrm{L} / \mathrm{min}$, a $25^{\circ} \mathrm{C}$, com os inibidores purificados nas concentrações de 1, 2, 4, 8, 16, 32, 64 e $128 \mathrm{nM}$. Várias curvas foram medidas em duplicata para obtermos um melhor ajuste experimental. Foram realizadas injeções de $60 \mu \mathrm{L}$ dos inibidores. Durante o tempo de injeção, a associação do inibidor à tripsina foi monitorada e após o seu término, a dissociação do complexo foi monitorada por $10 \mathrm{~min}$. Uma solução de $\mathrm{MgCl}_{2} 4 \mathrm{M}$ contendo Acetato de Sódio 0,1 M pH 4,5 foi usada na regeneração do chip.

Para os ensaios de cinética, foram utilizados o software BIAevaluation Version 4.1 e o ajuste das curvas experimentais de acordo com o modelo de ligação 1:1 (Langmuir).

\section{2.3.2.2 - Ensaio com quimotripsina}

A imobilização da quimotripsina também se deu pela técnica do acoplamento amina, utilizando $20 \mu \mathrm{L}$ da enzima a 1,2 $\mu \mathrm{M}$ em Acetato de Sódio $10 \mathrm{mM}, \mathrm{pH}$ 5,5, 
seguida pela lavagem com o mesmo tampão HBS-EP, à temperatura ambiente. Os níveis finais da imobilização foram por volta de 1350 RU. Um segundo sensorchip com nível de imobilização da quimotripsina por volta de 450 RU também foi utilizado para efeito de comparação.

Os ensaios de ligação foram realizados sob um fluxo de $30 \mu \mathrm{L} / \mathrm{min}$, a $25^{\circ} \mathrm{C}$, com os inibidores nas concentrações de 2, 4, 8, 16, 32, 64 e 128 nM. As injeções dos inibidores foram de $60 \mu \mathrm{L}$ e a associação do inibidor à quimotripsina foi monitorada durante este tempo. Após injeção, a dissociação do complexo foi monitorada por 10 min. A regeneração do chip foi feita com $\mathrm{MgCl}_{2} 2 \mathrm{M}$ contendo Acetato de Sódio 0,1 $\mathrm{M} \mathrm{pH} \mathrm{4,5.} \mathrm{O} \mathrm{mesmo} \mathrm{software} \mathrm{foi} \mathrm{utilizado} \mathrm{para} \mathrm{o} \mathrm{ajuste} \mathrm{experimental} \mathrm{das} \mathrm{curvas.}$

\section{2.3.3 - Determinação da seqüência N-Terminal}

Amostras dos inibidores purificados por cromatografia de fase reversa foram reduzidas e alquiladas, conforme o seguinte procedimento: 2 nmol de cada inibidor foram dissolvidos em $300 \mu \mathrm{L}$ de tampão Tris- $\mathrm{HCl}$ 0,25 M pH 8,0 contendo $6 \mathrm{M}$ de guanidina-HCl, $2 \mathrm{mM}$ de EDTA e $5 \mu \mathrm{L}$ de $\beta$-mercaptoethanol. A mistura de reação foi incubada por 4 horas, a $37^{\circ} \mathrm{C}$, no escuro em atmosfera de $\mathrm{N}_{2}$. Após este período foi adicionado à mistura $5 \mu \mathrm{L}$ de 4-vinil-piridina, seguida da incubação por mais 2 horas nas mesmas condições. A reação foi interrompida com a adição de $5 \mu \mathrm{L}$ de ácido acético $10 \%$.

Cada mistura foi separada por cromatografia de fase reversa em coluna $\mathrm{C}_{18}$ no sistema HPLC, na qual a absorbância foi monitorada em $220 \mathrm{~nm}$. A coluna foi previamente equilibrada com TFA $0,1 \%$ em $\mathrm{H}_{2} \mathrm{O}$ e posteriormente eluída num 
gradiente 0 a $100 \%$ do solvente TFA $0,1 \%$ em $90 \%$ de acetonitrila, sob um fluxo de $1 \mathrm{~mL} / \mathrm{min}$, durante 60 minutos.

A análise da seqüência $\mathrm{N}$-terminal das cadeias polipeptídicas dos inibidores foi realizada através da degradação de Edman, num seqüenciador automatizado de proteínas, junto ao laboratório da Profa. Dra. Heloisa S. S. de Araújo, do Departamento de Ciências Fisiológicas, da Universidade Federal de São Carlos.

A seqüência de resíduos obtidos pela degradação de Edman automatizada foi submetida ao sistema de busca NCBI-BLAST (Altschul et al, 1990) a fim de encontrar proteínas que apresentassem identidade seqüencial com os inibidores de Acacia plumosa. O programa CLUSTAL X (Higgins and Sharp, 1988) foi utilizado para realizar o alinhamento entre as seqüências dos resíduos de aminoácidos $\mathrm{N}$ terminal dos inibidores da A. plumosa com a seqüência de demais inibidores de proteases. $\mathrm{O}$ alinhamento foi realizado com a região $\mathrm{N}$-terminal da cadeia $\mathrm{A}$ e também com a região N-terminal da cadeia B de cada um dos inibidores.

\section{2.3.4 - Espectrometria de Massas}

A espectrometria de massas é uma técnica analítica usada para identificar compostos, quantificar materiais, elucidar algumas propriedades estruturais e químicas de moléculas e determinar as razões isotópicas dos átomos na amostra (ASMS, 1998). A fim de converter moléculas individuais em íons, a espectrometria de massas requer a utilização de uma técnica de ionização. Uma das mais empregadas na determinação de massas moleculares é a de electrospray, na qual a solução de interesse é bombeada num capilar metálico mantido a um potencial 
(positivo ou negativo). O campo elétrico leva a um acúmulo de carga na ponta do capilar, seguida pela emissão de gotículas com excesso de carga que passam por um processo de evaporação do solvente e fissão eletrostática que culmina com a expulsão dos íons para a fase gasosa. Esta técnica permite a determinação de moléculas com altas massas moleculares, uma vez que é capaz de produzir abundantemente íons multiplamente carregados.

Dentre os analisadores de $\mathrm{m} / \mathrm{z}$, o quadrupolo tem sido o mais comumente empregado em equipamentos comerciais de uso geral. Neste tipo de filtro, os íons são injetados paralelamente a quatro barras metálicas, às quais são aplicadas combinações de potenciais elétricos de corrente contínua (DC) e alternada (AC). A variação dos potenciais DC aplicados às barras metálicas faz com que somente íons com uma determinada relação $\mathrm{m} / \mathrm{z}$ tenham trajetórias estáveis e cheguem até o final do percurso (Neto, 2003).

Foram realizados experimentos a fim de se determinar a razão massa/carga $(\mathrm{m} / \mathrm{z})$ e de se verificar a presença de isoformas na fração que mostrou atividade anticoagulante proveniente da exclusão molecular (ApPIII) na forma intacta. Foram também realizados experimentos com o produto da digestão tríptica de ApPIII, a fim de se determinar a seqüência de alguns peptídeos internos desta fração.

Para a redução, alquilação e digestão tríptica desta fração, utilizamos o seguinte protocolo: $100 \mu \mathrm{g}$ do inibidor (liofilizados em sistema SpeedVac) foram resuspendidos em $25 \mu \mathrm{L}$ de $\mathrm{NH}_{4} \mathrm{HCO}_{3}$ 0,1 M com 50\% de $\mathrm{ACN}$. A redução se deu pela adição de $5 \mu \mathrm{L}$ de DTT $(45 \mathrm{mM})$, e a mistura foi incubada por 1 hora a $56^{\circ} \mathrm{C} \mathrm{em}$ atmosfera de $\mathrm{N}_{2}$. Após este tempo, foram adicionados $5 \mu \mathrm{L}$ de Iodoacetamida 100 $\mathrm{mM}$, e a incubação se deu por mais 2 horas a temperatura ambiente, no escuro. Antes do início da digestão com tripsina, foram adicionados a mistura $140 \mu \mathrm{L}$ de $\mathrm{NH}_{4} \mathrm{HCO}_{3}$ 
0,1 M, e a tripsina foi adicionada numa proporção de 1:50. A digestão ocorreu overnight a $37^{\circ} \mathrm{C}$, e a reação foi interrompida com $5 \mu \mathrm{L}$ de ácido fórmico.

As amostras foram analisadas pela espectrometria de massa, no espectrômetro Quattro II Eletrospray Triple Quadrupole MS (Micromass, Manchester, UK), junto ao Laboratório de Bioquímica de Proteínas, do Prof. Dr. José César Rosa, no Laboratório de Química de Proteínas, junto ao Hemocentro - USP campus de Ribeirão Preto.

\section{2.3.5 - Espectroscopia de dicroísmo circular (CD) e cálculo}

\section{das frações de estrutura secundária}

O fenômeno de dicroísmo circular (Circular Dichroism, CD) é a propriedade observada numa molécula que possui centros assimétricos (centro quiral), quando ela absorve diferenciadamente a luz circularmente polarizada à direita e a luz circularmente polarizada à esquerda (Campbell \& Dwek, 1984).

Peptídeos e proteínas são amplamente estudados por CD, pois os principais centros quirais destas moléculas $\left(\mathrm{C}_{\alpha}\right)$ estão ao longo da cadeia principal. Portanto, seus espectros de CD na região entre 180 e 260 nm (região do UV-distante) fornecem informações capazes de caracterizar e discriminar estruturas secundárias ( $\alpha$-hélice, fitas- $\beta$, voltas e estruturas não-ordenadas) presentes nestas moléculas (Sreerama et al, 2001). A Figura 4 mostra os espectros de CD de proteínas compostas por diferentes tipos de estrutura secundária.

A espectroscopia de CD em proteínas e peptídeos é uma ferramenta muito utilizada no estudo de mudanças conformacionais (sofridas devido a variações de 
solventes, temperatura e de $\mathrm{pH}$ ), na interação com ligantes e em ensaios de desnaturação e renaturação de proteínas (Nakanishi et al, 1994; Kelly \& Price, 1997).

A estimativa do conteúdo das frações de estrutura secundária de uma proteína é feita com base num grupo de proteínas de referência que possuem estrutura secundária e espectros de CD conhecidos. Com o auxílio de programas computacionais, que utilizam diferentes métodos de desconvolução, são extraídas as componentes comuns dos espectros de CD da proteína analisada e a porcentagem que as mesmas representam no espectro (Sreerama et al, 2000).

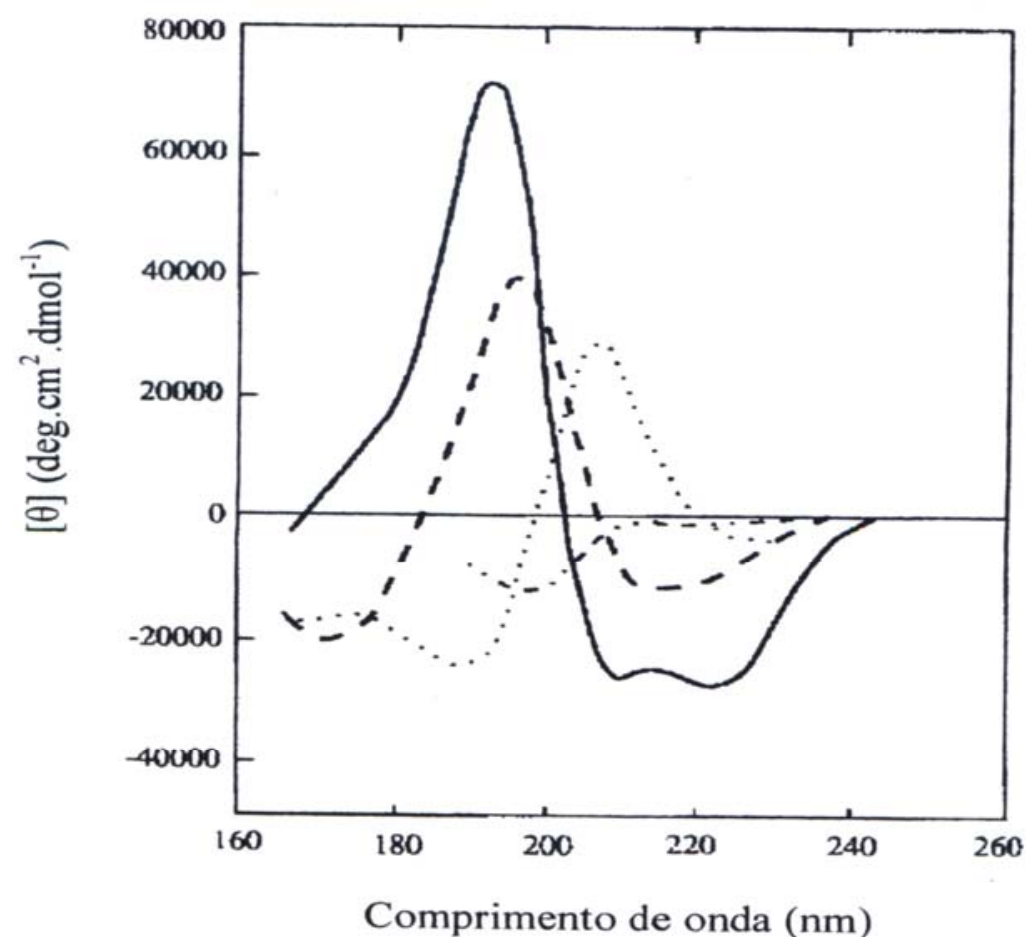

Figura 4 - Espectro de CD de vários tipos de estrutura secundária. Os espectros representam $\alpha$-hélice $(-)$, folha- $\beta(---)$, voltas- $\beta(\cdots)$ e estrutura irregular $\left({ }^{\circ}--\right)$. Modificada a partir de Kelly \& Price, 1997.

Os espectros de $\mathrm{CD}$ dos isoinibidores purificados foram registrados no espectropolarímetro J-715, na faixa de 195 a $250 \mathrm{~nm}$ em cubetas cilíndricas de 
quartzo de caminho óptico de $1 \mathrm{~mm}$, com uma média de 16 varreduras. Os inibidores encontravam-se em solução de PBS numa concentração de $0,3 \mathrm{mg} / \mathrm{mL}$. As contribuições dos tampões foram subtraídas dos espectros dos inibidores e o resultado foi expresso em elipticidade molar $[\theta]$. Os espectros originais foram filtrados com o Filtro de Fourier, preservando as bandas típicas de cada espectro.

As contribuições de estrutura secundária pelo espectro de $\mathrm{CD}$ dos inibidores foram realizadas utilizando o pacote de desconvolução CDPro, com os programas Selcon3, Continll e CDSSTR, utilizando um grupo de proteínas de referência contendo 43 espectros de CD (Johnson et al, 1986; Keiderling et al, 1991; Yang et al, Sreerama et al) .

\section{2.3.6 - Espectroscopia de fluorescência}

A absorção da radiação eletromagnética de um determinado comprimento de onda por um cromóforo, faz com que seus elétrons passem do estado eletrônico fundamental para um estado eletrônico excitado. Muitas vezes, esta energia de excitação é perdida para o meio sob a forma de calor, sucedendo retorno do elétron para o estado fundamental. A fluorescência ocorre quando este elétron retorna para o estado fundamental através do seu decaimento do menor nível de energia vibracional do estado eletrônico excitado $\left(S_{1}\right)$ para o estado eletrônico fundamental $\left(S_{0}\right)$ pela da emissão de um fóton, cujo comprimento de onda é maior que o da excitação (Campbell \& Dwek, 1984). A Figura 5 ilustra este processo. 


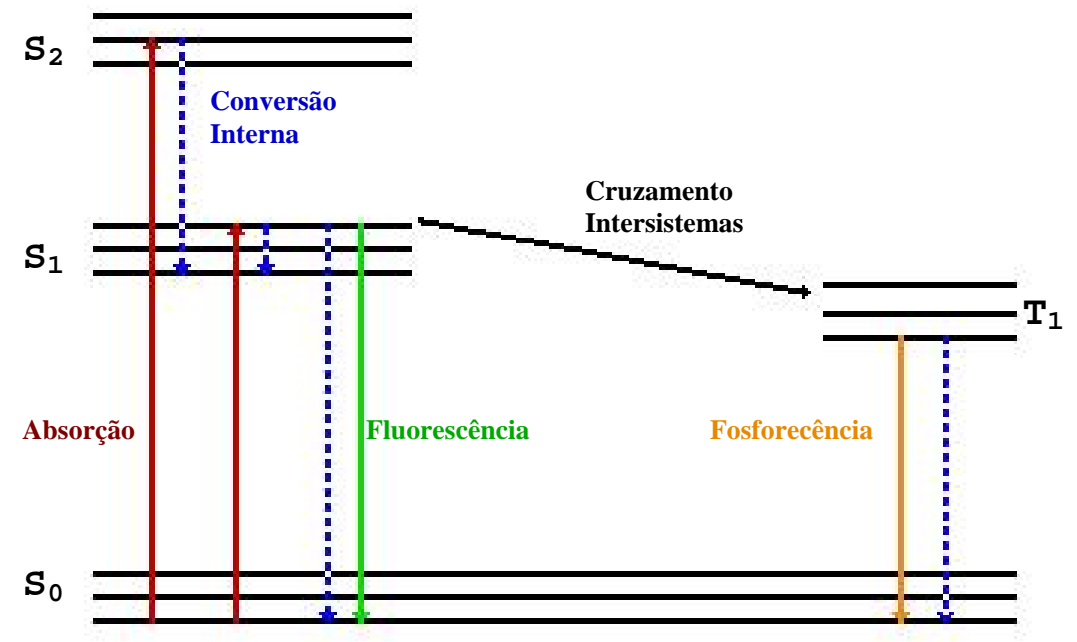

Figura 5 - Diagrama de Jablonski. A absorção de determinada quantidade de energia faz com que um elétron passe do menor estado vibracional do estado fundamental $\left(\mathrm{S}_{0}\right)$ para um estado vibracional superior do estado excitado $\mathrm{S}_{1}$ ou $\mathrm{S}_{2}$ (setas vermelhas). Após passar por processos não radiativos (setas azuis), que conduzem o elétron ao menor nível vibracional do primeiro estado excitado, pode ocorrer emissão de fluorescência (seta verde), que é a emissão de um fóton devido ao decaimento do estado $S_{1}$ para o estado fundamental $S_{0}$. A relaxação do elétron também pode ocorrer pela emissão de um fóton devido ao decaimento de um estado tripleto $\left(\mathrm{T}_{1}\right)$ para o estado eletrônico fundamental $\left(\mathrm{S}_{0}\right)$, processo chamado de fosforência (seta amarela).

A espectroscopia de emissão de fluorescência estática também é largamente usada no estudo de proteínas e peptídeos para fornecer informações relacionadas às vizinhanças dos grupos fluorescentes (fluorórofos naturais), que em proteínas são os aminoácidos aromáticos: Phe, Tyr e Trp. A fluorescência destes resíduos é altamente sensível ao ambiente em que se encontram, portanto, monitorar suas alterações pelos parâmetros da espectroscopia de fluorescência, tais como posição do máximo de emissão $\left(\lambda_{\max }\right)$ e mudanças no rendimento quântico $\left(\phi_{\mathrm{F}}\right)$ devido à ação de solventes, 
ligantes e $\mathrm{pH}$, sugerem discretas mudanças conformacionais sofridas nas vizinhanças dos fluoróforos (Lakowicz, 1999).

As medidas de emissão de fluorescência dos inibidores foram realizadas a $25^{\circ} \mathrm{C}$ no espectrofluorímetro K2, modo estático. Amostras dos inibidores, em PBS pH 7,4 na concentração de $0,07 \mathrm{mg} / \mathrm{mL}$, foram excitadas em $280 \mathrm{~nm}$ e $295 \mathrm{~nm}$ e a emissão de fluorescência foi monitorada no intervalo de 290-450 e 305-450 nm, respectivamente. Cubetas retangulares de quartzo de $1 \mathrm{~cm}$ de caminho ótico foram utilizadas nas medidas. A fim de minimizar o efeito do espalhamento de luz, os espectros de emissão de fluorescência dos tampões em que os inibidores se encontravam foram subtraídos dos espectros das correspondentes amostras.

\section{2.3.7 - Ensaio de estabilidade frente a variações de pH}

Com o intuito de se analisar as possíveis mudanças conformacionais que seriam induzidas por influência do $\mathrm{pH}$, as amostras do inibidor foram incubadas em soluções tamponadas em diferentes pHs. A solução utilizada foi o tampão AcetatoBorato-Fosfato de Sódio $50 \mathrm{mM}$ de pHs 2,0; 4,0; 6,0; 8,0; 10,0 e 12,0.

Os espectros de CD e de emissão de fluorescência de cada um dos inibidores foram tomados após 24 horas de incubação à temperatura ambiente em cada um desses tampões.

A concentração das amostras para as medidas de CD foi de $0,2 \mathrm{mg} / \mathrm{mL}$, enquanto que para as medidas de emissão de fluorescência foi de $0,07 \mathrm{mg} / \mathrm{mL}$. 


\section{2.3.8 - Ensaio de estabilidade térmica}

A estabilidade térmica dos inibidores foi investigada, submetendo as amostras de ApTIA $(0,22 \mathrm{mg} / \mathrm{mL})$, ApTIB $(0,2 \mathrm{mg} / \mathrm{mL})$ e ApTIC $(0,3 \mathrm{mg} / \mathrm{mL})$ a uma variação térmica numa rampa de 5 a $95^{\circ} \mathrm{C}$ com aumentos regulares de temperatura de $5^{\circ} \mathrm{C}$ a cada 30 minutos de incubação. As amostras foram monitoradas no espectropolarímetro acoplado a um sistema de banho Peltier. Foram feitas 16 varreduras em cada temperatura selecionada, na faixa de 195 a $250 \mathrm{~nm}$, utilizando-se cubeta retangular de quartzo de $1 \mathrm{~mm}$ de caminho óptico. Após o ensaio de variação térmica, a amostra utilizada foi novamente incubada à temperatura ambiente para verificar se as mudanças estruturais sofridas devido à ação da temperatura eram reversíveis. Tais amostras foram também empregadas em ensaio de inibição da atividade da tripsina após o tratamento térmico.

\section{2.4 - Atividade biológica}

\section{2.4.1 - Atividade anticoagulante}

Amostras de sangue humano foram coletadas de doadores saudáveis em frascos contendo citrato de sódio $20 \mathrm{mM}(100 \mu \mathrm{L} / 1 \mathrm{~mL}$ de sangue). Após centrifugação e coleta do plasma sanguíneo, incubou-se por 30 minutos a $37^{\circ} \mathrm{C}, 250 \mu \mathrm{L}$ do plasma com $250 \mu \mathrm{L}$ de cada uma das amostras de interesse em tubos de vidro. Após incubação, adicionou-se $250 \mu \mathrm{L}$ de $\mathrm{CaCl}_{2} 100 \mathrm{mM}$. O teste foi realizado em 
duplicata para cada uma das amostras. O tempo inibição da coagulação de cada amostra foi cronometrado a partir da adição da solução de $\mathrm{CaCl}_{2}$. A atividade anticoagulante das amostras foram avaliadas com base num tubo controle constituído por plasma sanguíneo incubado com a solução de PBS.

\section{2.4.2 - Atividade de inibição de enzimas}

Amostras do EB, de ApPIII e de cada inibidor (50 $\mu \mathrm{L}$ de uma solução a 0,5 $\mathrm{mg} / \mathrm{mL}$ ) foram incubadas com tripsina ( $50 \mu \mathrm{L}$ de uma solução a $0,03 \mathrm{mg} / \mathrm{mL}$ ) a $37^{\circ}$ em tubos de vidro. Após 30 minutos de incubação, adicionou-se $50 \mu \mathrm{L}$ do reagente sintético BAPNA $(50 \mu \mathrm{L}$ de uma solução a $1,25 \mathrm{mM})$ a fim de verificar quais das amostras eram capazes de inibir a ação da enzima sobre o seu substrato. A leitura da absorbância dos tubos foi realizada em $405 \mathrm{~nm}$. Este ensaio também contou com a preparação de um tubo controle, que continha apenas PBS e a enzima empregada no teste, observando-se assim a ação máxima da enzima.

Amostras de ApPIII (2mg/mL) foram colocadas em tampão Tris-HCl 25 mM pH 7,5 com 0,5 M de NaCl. O ensaio de inibição se deu utilizando 2,9 mL do tampão Tris- $\mathrm{HCl} 25 \mathrm{mM}$ pH 7,5 com 0,5 M de $\mathrm{NaCl}$ contendo o substrato Hippuril-Phe 1 $\mathrm{mM}$ juntamente com $100 \mu \mathrm{L}$ de uma solução enzimática de carboxipeptidase $\mathrm{A}$ $(0,005 \mathrm{mg} / \mathrm{mL})$, para a preparação do tubo controle. A leitura da absorbância dos tubos foi realizada em $254 \mathrm{~nm}$. Para o tubo das amostras, foram adicionados $100 \mu \mathrm{L}$ de ApPIII com 2,8 mL do tampão e mais $100 \mu \mathrm{L}$ da solução enzimática. 


\section{2.4.3 - Atividade sobre fungos fitopatogênicos}

A atividade antifúngica foi observada pela incubação dos inibidores juntamente com os esporos dos fungos fitopatogênicos Aspergillus chevalier, Aspergillus fumigatus, Aspergillus niger, Botrytis cinerea, Colletotrichum gloeosporioides, Colletotrichum lindemuthianum, Colletotrichum musae, Colletotrichum sp. F37, Colletotrichum sp. P10, Colletotrichum truncatum, Fusarium graminearum, Fusarium moniliforme, Fusarium oxysporum, Fusarium pollidoroseum, Hendersonina sp, Lasiodiplodia theobromae, Mucor sp, Phomopsis sp, Pyricularia sp, Pythium oligandrum, Rhizoctonia solani, Thielaviopis paradoxa, Trichoderma viridae, em meios de cultura propícios as crescimento de tais espécies.

Os esporos dos fungos fitopatogênicos Aspergillus niger e Fusarium moniliforme foram gentilmente cedidos pelo Prof. Dr. Odair José Pereira da Universidade Federal do Amazonas, as espécies Pyricularia sp, Thielaviopsis paradoxa, Trichoderma viridae e Hendersonina sp foram doados pela Profa. Silvana Perissatto Meneghin Universidade Federal de São Carlos, campus de Araras. As demais cepas foram cedidas pela Profa. Dra. Vânia Maria Maciel Melo do Departamento de Biologia da Universidade Federal do Ceará.

Foram realizados dois ensaios para verificar uma possível inibição do crescimento dos fungos. O primeiro foi realizado em duplicata em microplacas de 96 poços, na qual se realizou uma diluição duplo-seriada da amostra de interesse. $\mathrm{O}$ primeiro poço da placa foi incubado adicionando-se $140 \mu \mathrm{g}$ da amostra juntamente com $50 \mu \mathrm{L}$ do meio BD (batata-dextrose) e $10 \mu \mathrm{L}$ de uma solução contendo $10^{7}$ esporos $/ \mathrm{mL}$ de cada um dos fungos testados. A microplaca foi incubada por 6 dias a $28^{\circ} \mathrm{C}$ e a avaliação da inibição do crescimento micelar foi realizada visualmente, 
tendo-se por base um poço controle, no qual os esporos foram incubados apenas com o meio nutritivo e PBS. Este ensaio foi realizado com as espécies de Aspergillus niger, Thielaviopis paradoxa, Colletotrichum sp. F37, Colletotrichum sp. P10, Pyricularia sp, Hendersonina sp, Fusarium graminearum e Fusarium moniliforme.

O segundo ensaio foi realizado em placas de Petri contendo o meio BDA (batata-dextrose-agarose). Nestas placas, foram depositados três discos de papel filtro igualmente espaçados entre si. Em um dos discos foram depositados $100 \mu \mathrm{g}$ do inibidor que se encontrava em solução de PBS pH 7,4, no segundo disco foram depositados $50 \mu \mathrm{g}$ e sobre o terceiro disco foi depositado o tampão PBS. Este último disco foi utilizado como controle do crescimento dos fungos. No centro da placa foram depositadas as porções vegetativas de cada um dos fungos empregados neste ensaio. Em seguida, a placa foi incubada por 5 dias a uma temperatura de $28^{\circ} \mathrm{C}$ para prosseguir-se com a avaliação visual do crescimento dos fungos sobre as placas. Este ensaio foi realizado com as demais espécies de fungos já citadas. 


\section{III - RESULTADOS E DISCUSSÃO}

\section{1 - Obtenção do extrato bruto (EB)}

O extrato bruto foi obtido a partir da dissolução de $2 \mathrm{~g}$ do pó dos cotilédones de Acacia plumosa (triturados em almofariz) em $20 \mathrm{~mL}$ da solução de PBS, sob agitação por 2 horas a $4^{\circ} \mathrm{C}$. Após centrifugação a $10.000 \mathrm{rpm}$ e separação da fração sobrenadante, obtivemos um volume de extrato bruto de $17 \mathrm{~mL}$, que foram submetidos à diálise em sacos YM-3. Após este processo, o EB foi empregado em ensaios de inibição da coagulação sanguínea e de inibição da ação enzimática da tripsina. Estes experimentos demonstraram a presença de propriedades anticoagulantes e atividade de inibição da ação da tripsina in vitro no EB das sementes de A. plumosa. Essas propriedades têm sido demonstradas em vários trabalhos, e se devem à presença de inibidores de proteases que podem interferir na cascata de coagulação sangüínea, bem como inibir a ação de enzimas proteolíticas como tripsina (Lin et al, 1991; Batista et al, 1996; Bhattacharyya et al, 2006), quimotripsina (Teles et al, 2004), calicreína (Oliva, 1999), e outras.

\section{2 - Purificação do Inibidor}

\section{2.1 - Cromatografia de Exclusão Molecular}

O EB de A.plumosa foi aplicado em coluna Superdex-75 e, sua eluição revelou 3 picos majoritários (Figura 6). As frações correspondentes a estes picos 
foram coletadas individualmente e testadas quanto à capacidade de inibição da coagulação do plasma sanguíneo e quanto à capacidade de inibição da ação enzimática da tripsina. Somente nas frações 13, 14 e 15, que correspondem ao terceiro pico eluído nesta etapa cromatográfica, foram determinadas tais atividades. Estas frações foram reunidas e denominadas ApPIII (pois corresponde ao terceiro pico da SEC do EB de A.plumosa), correspondem a moléculas com massa molecular em torno de $20 \mathrm{kDa}$, segundo a curva de calibração da Superdex 75, construída com base na posição de eluição dos padrões de massa molecular nas mesmas condições descritas (Figura 7).

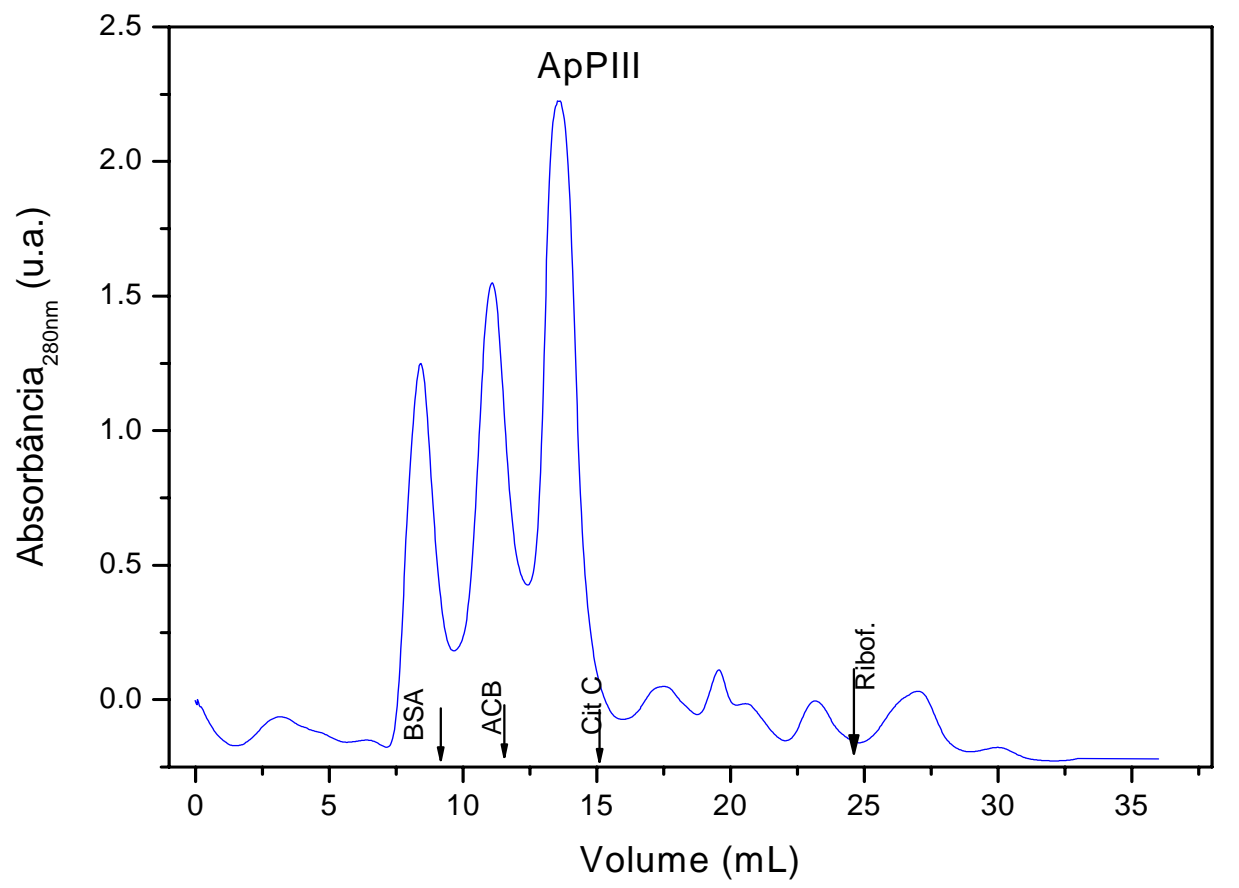

Figura 6 - Cromatografia de exclusão molecular do EB de A. plumosa. Gel filtração do EB das sementes de A. plumosa em coluna de Superdex-75, previamente equilibrada e em seguida eluída com PBS ( $\mathrm{pH} 7.4$ ) sob um fluxo de $0,5 \mathrm{~mL} / \mathrm{min}$, com frações coletadas de $1,0 \mathrm{~mL}$. As frações que apresentaram atividade anticoagulante e de inibição sobre tripsina, foram denominadas ApPIII. As setas indicam as posições da eluição dos padrões de massa molecular, usados na calibração da coluna, são eles: BSA (66 kDa), ACB (45 kDa), Cit C (12,4 kDa) e Riboflavina (375 Da). 
A fração denominada ApPIII foi então coletada separadamente, e posteriormente dialisada contra o tampão Acetato de Sódio $50 \mathrm{mM}(\mathrm{pH} 5,0)$ para ser submetida a uma cromatografia de troca iônica.

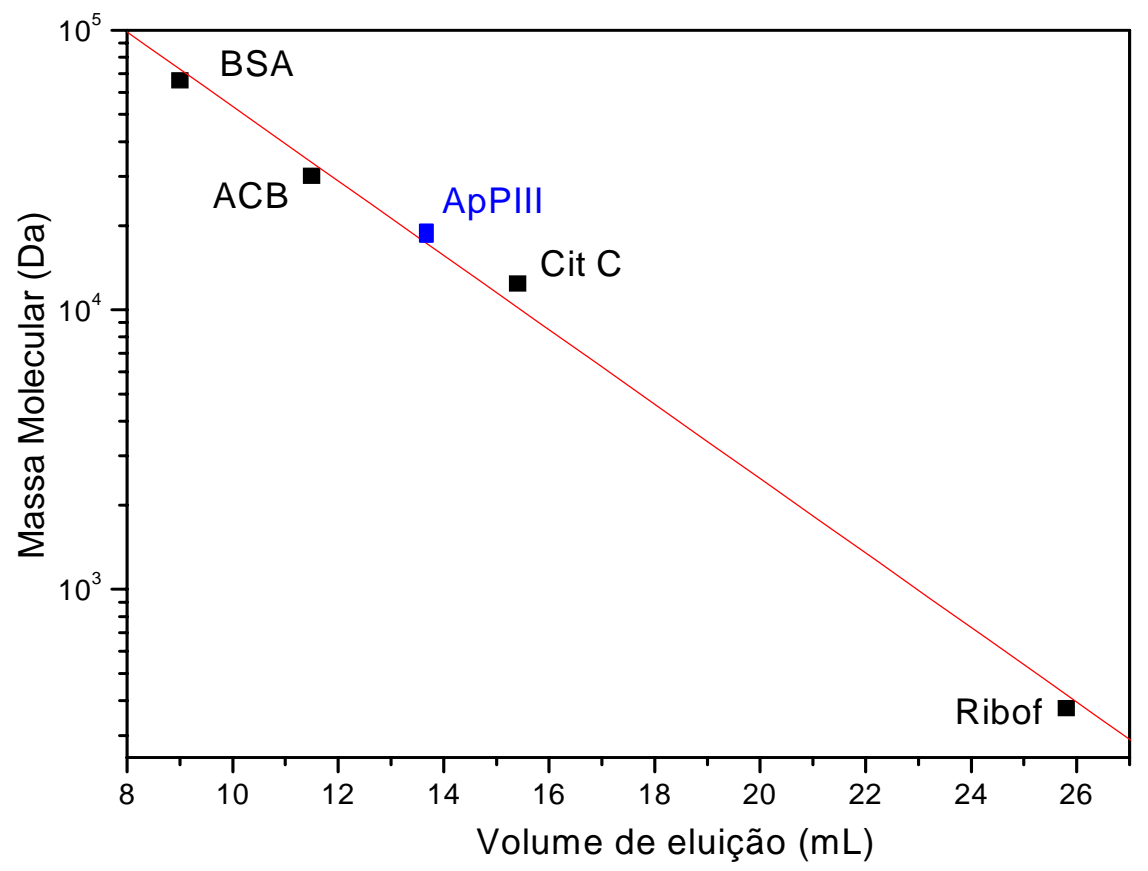

Figura 7 - Determinação do peso molecular aparente de ApPIII. Curva de calibração criada com a posição de eluição dos padrões de massas moleculares conhecidas, em eluições nas mesmas condições da eluição do EB de A. plumosa. De posse da equação da reta que descreve a curva de calibração foi determinada o peso molecular aparente por volta de $20 \mathrm{kDa}$ para a fração denominada ApPIII. Os padrões moleculares usados na calibração da coluna foram BSA, ACB, Cit $\mathrm{C}$ e Ribof, e o volume de eluição de cada um deles foi de 9,1 mL; 11,5 mL; 15,4 mL e $25,8 \mathrm{~mL}$, respectivamente.

\section{2.2 - Cromatografia de Troca Iônica}

O perfil cromatográfico da eluição de ApPIII em coluna MonoS revelou a presença de pelo menos 6 picos majoritários, no entanto as atividades 
anticoagulante e de inibição da tripsina foram detectadas em apenas 4 deles, os quais foram eluídos por volta de $0,18,0,22,0,32$ e $0,37 \mathrm{M}$ de $\mathrm{NaCl}$, no gradiente salino linear de 0 a $0,5 \mathrm{M}$ de $\mathrm{NaCl}$ em 50 minutos. Tais picos foram nomeados de acordo com a ordem de eluição passando então a ser chamados de ApTIA (Acacia plumosa trypsin inhibitor, A), ApTIB, ApTIC e ApTID, respectivamente (dados mostrados na Figura 8).

A presença de isoinibidores purificados em sementes de plantas é notadamente marcada, como por exemplo, as 4 isoformas de inibidores de proteases nas sementes de Archidendron ellipticum (Battacharyya et al, 2006), as 10 isoformas nas sementes de Pisum sativum (Morrison et al, 2005).

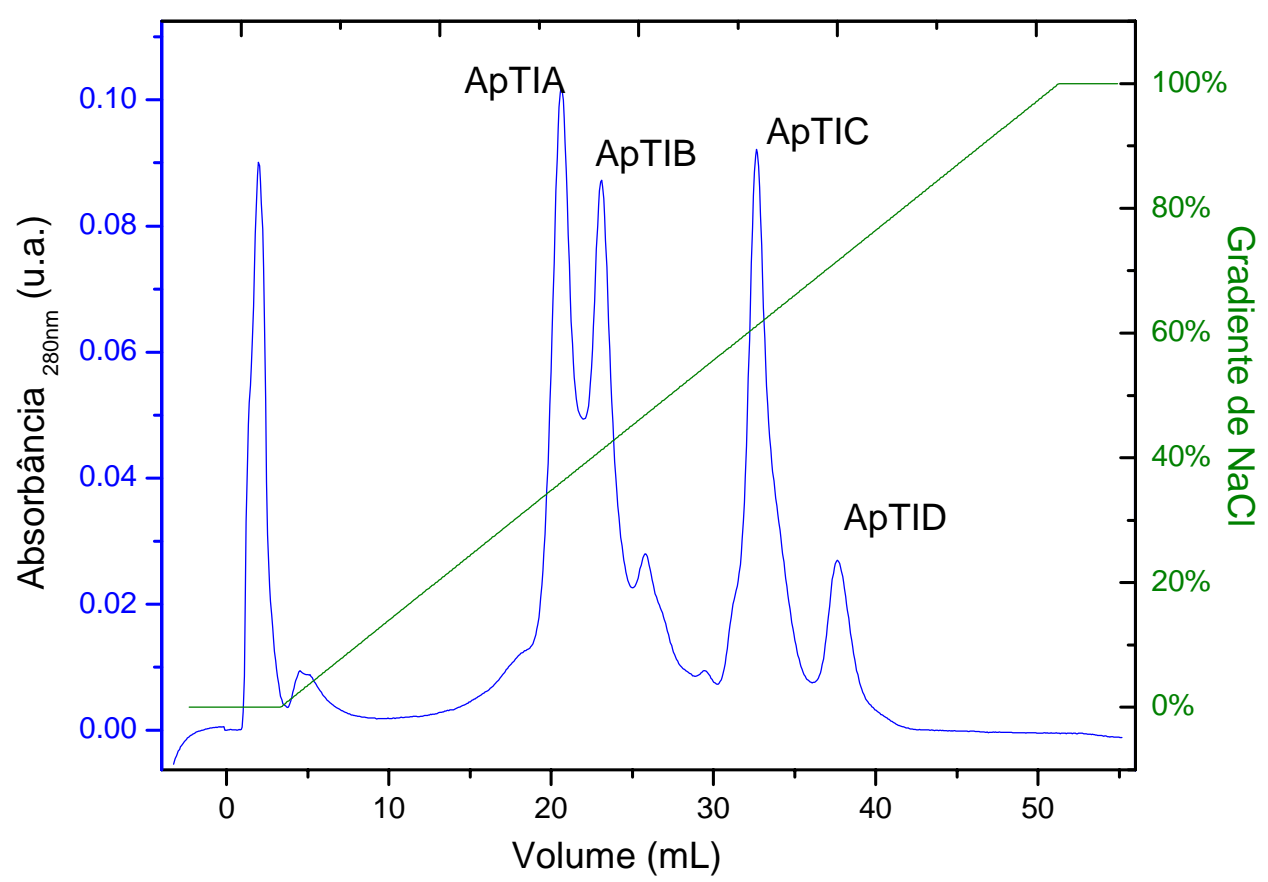

Figura 8 - Perfil cromatográfico de ApPIII em coluna de troca iônica. ApPIII foi submetido a uma cromatografia de troca iônica em coluna Mono-S. A coluna foi eluída e equilibrada com tampão Acetato de Sódio $50 \mathrm{mM}, \mathrm{pH} \mathrm{5,0} \mathrm{num}$ gradiente salino linear de 0 a $0,5 \mathrm{M}$ de $\mathrm{NaCl}$ em 50 minutos, sob um fluxo de 1,0 $\mathrm{ml} / \mathrm{min}$. Foram coletadas frações de $0,5 \mathrm{ml}$, sendo as que apresentaram atividade anticoagulante e inibição sobre tripsina, denominadas de ApTIA, ApTIB e ApTIC e ApTID. 


\section{2.3 - Eletroforese em Gel de Poliacrilamida}

A análise da eletroforese em gel de poliacrilamida das amostras provenientes de cada uma das etapas cromatográficas do EB de A.plumosa está mostrada na Figura 9(A). A massa molecular aparente da fração ApPIII em torno de $20 \mathrm{kDa}$, pode ser confirmada devido a presença de uma banda no gel em condições nãoredutoras. Após a redução desta fração com $\beta$-mercaptoetanol, foram estimadas duas outras bandas: uma por volta de $14 \mathrm{kDa}$ e outra por volta de $6 \mathrm{kDa}$.

A massa molecular aparente dos inibidores ApTIA, ApTIB, ApTIC e ApTID, mostrada na Figura 9(B), foi determinada com as amostras sob condições nativas devido à presença de uma única banda em torno de $20 \mathrm{kDa}$. No entanto, sob condições redutoras, estes inibidores apresentaram duas bandas, indicando que são constituídos por duas cadeias polipeptídicas, sendo uma cadeia- $\alpha$ de massa molecular maior e uma cadeia- $\beta$ de massa molecular menor, unidas covalentemente por ligação dissulfeto. Os inibidores ApTIA e ApTIB apresentam uma banda por volta de $16 \mathrm{kDa}$ e outra por volta de $6 \mathrm{kDa}$. Já ApTIC e ApTID apresentaram uma banda em $15 \mathrm{kDa}$ e outra por volta de $5 \mathrm{kDa}$.

As massas moleculares encontradas para as duas cadeias de cada um dos inibidores está de acordo com trabalhos que estabelecem a purificação e a caracterização de inibidores de proteases do tipo Kunitz extraídos de leguminosas, tais como os de Leucaena leucocephala (Oliva et al,2000), Pithecellobium dulce (Vargas et al, 2004) e Archidendron ellipticum (Bhattacharyya et al, 2006). 


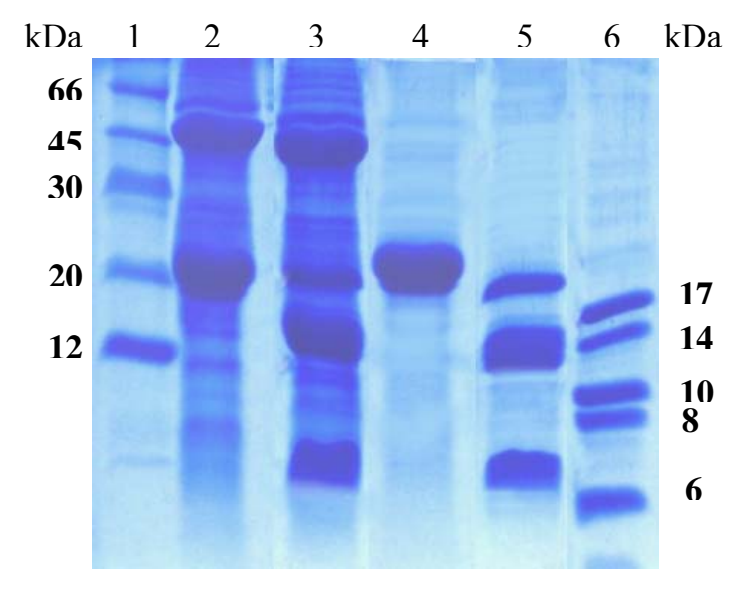

A

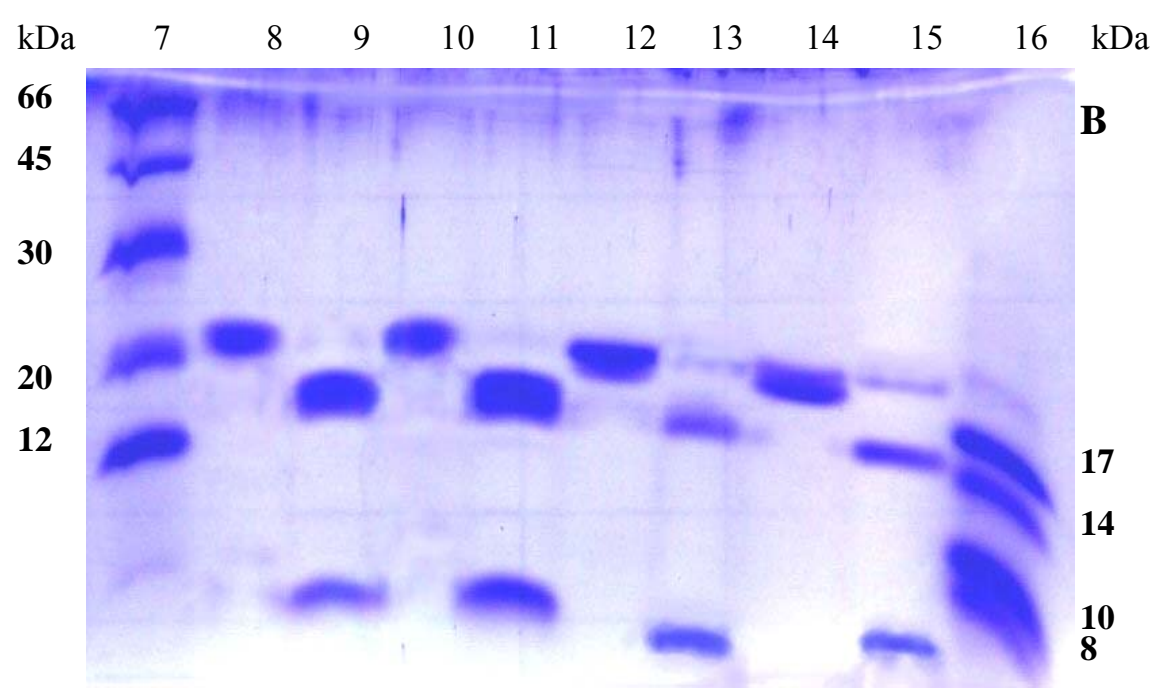

Figura 9 - SDS-PAGE das frações provenientes das etapas cromatográficas. Mostrando em (A) as frações eluídas da gelfiltração do EB de A.plumosa. Os poços correspondem a: 1 - Padrões de alto peso molecular; 2 - EB em condições nativas; 3 - EB na presença de $\beta$-mercaptoetanol; 4 - ApPIII em condições nativas; 5 - ApPIII na presença de $\beta$-mercaptoetanol; 6- Padrões de massa molecular de baixo peso; e em (B), as frações provenientes da eluição de ApPIII em coluna de troca iônica. Os poços correspondem a: 7 - Padrões de alto peso molecular;; 8 - ApTIA; 9 - ApTIA na presença de $\beta$-mercaptoetanol; 10 - ApTIB; 11 - ApTIB na presença de $\beta$-mercaptoetanol; 12 - ApTIC; 13 - ApTIC na presença de $\beta$-mercaptoetanol; 14 - ApTID; 15 - ApTID na presença de $\beta$ mercaptoetanol; 16 - Padrões de baixo peso molecular. O gel foi corado com Coomassie Blue R 250. 
Estes resultados são indicativos de que estamos diante de pelo menos 4 diferentes isoformas deste inibidor, uma vez que todos mostram o mesmo padrão de massa molecular, antes e após tratamento com agente redutor. Assim passamos a denominar ApTI (A, B, C, D significando cada uma das isoformas).

\section{2.4 - Cromatografia de Interação Hidrofóbica}

Após purificação em coluna de troca iônica, as isoformas dos inibidores (ApTIA, ApTIB, ApTIC e ApTID), todos em condições nativas, foram submetidos a uma cromatografia de fase reversa em coluna $\mathrm{C}_{18}$, acoplada ao sistema HPLC.

O grau de pureza satisfatório das frações correspondentes às isoformas provenientes da cromatografia de troca iônica foi verificado também durante esta etapa cromatográfica, devido a presença de um único pico correspondente a eluição de cada uma das isoformas.

O tempo de retenção das isoformas ApTIA e ApTIB, no gradiente linear gerado pelos solventes A e B (Solvente A: 0,1\% de TFA em água e Solvente B: 90\% Acetonitrila com $0,1 \%$ de TFA em água), mostrados no perfil de eluição da Figura 10, foi de 26 minutos, o que corresponde a uma hidrofobicidade de $52 \%$ neste gradiente. Já para a eluição dos inibidores ApTIC e ApTID o tempo de retenção foi de 27 minutos, que corresponde a uma hidrofobicidade de 55\% no mesmo gradiente. 

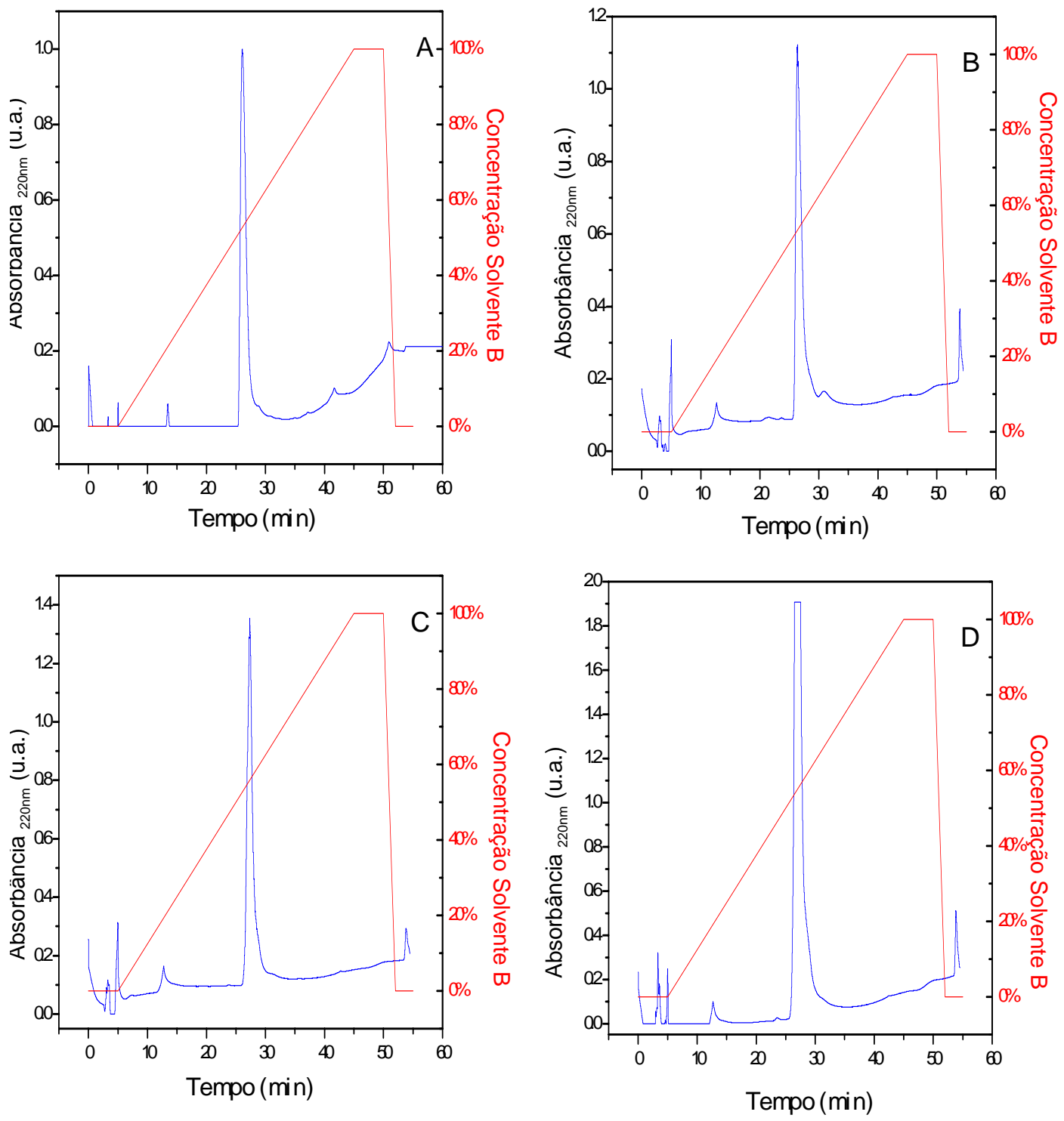

Figura 10 - Perfil cromatográfico dos inibidores em condições nativas em $C_{18}$. Amostras dos inibidores foram aplicadas em coluna de interação hidrofóbica equilibrada com TFA $0,1 \%$, sendo eluídas num fluxo de $1,0 \mathrm{~mL} / \mathrm{min}$ num gradiente linear de 0 a $100 \%$ do Solvente B (Acetonitrila 90\% com 0,1\% de TFA) durante 50 minutos. Em (A), o perfil de eluição de ApTIA, eluído em 26 minutos; em (B), o perfil de ApTIB, eluído em 26 minutos; em (C), o perfil de ApTIC, eluído em 27 minutos e em (D), o perfil de ApTID, eluído em 27 minutos. 
A fim de serem submetidos às reações de redução e alquilação das cadeias polipeptídicas, os inibidores foram também submetidos a esta eluição em $\mathrm{C}_{18}$ para posteriormente serem submetidos à análise da seqüência N-Terminal pela degradação de Edman automatizada.

A reação de redução e alquilação das cadeias polipeptídicas mostrou-se capaz de separar as cadeias unidas por pontes S-S. As frações eluídas foram coletadas, liofilizadas em sistema SpeedVac, ressuspendidas em água e finalmente avaliadas por eletroforese, de acordo com o mostrado na Figura 11.

O início da eluição da cadeia de massa molecular menor se dá num tempo de retenção de 28 minutos, no entanto, nesta fração verifica-se a presença de contaminantes (pela eletroforese da Figura 12). Estes contaminantes podem ser ainda os produtos da reação que estão sendo co-eluídos com a cadeia polipeptídica menor do inibidor. A fração eluída no tempo de retenção de 29 minutos apresenta um melhor grau de pureza, correspondendo então a cadeia de aproximadamente 5 kDa. A cadeia eluída em 32 minutos corresponde a cadeia de maior massa molecular $(15 \mathrm{kDa})$.

Estes resultados são compatíveis com os dados descritos na literatura para os inibidores de proteases do tipo Kunitz, no qual elas são formados por 2 cadeia polipeptídicas, uma maior por volta de $15 \mathrm{kDa}$ e outra menor de aproximadamente $5 \mathrm{kDa}($ Oliva, 2000). 


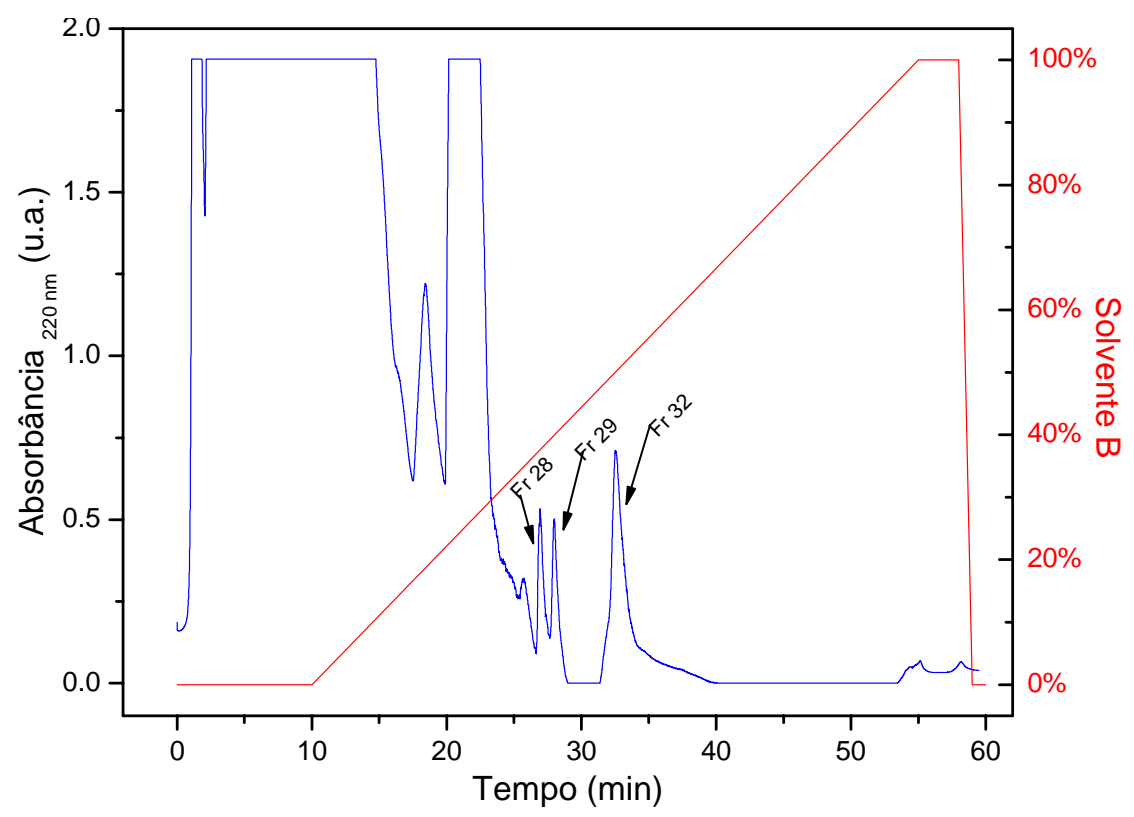

Figura 11 - Perfil cromatográfico de ApTIB reduzida e alquilada em $\mathrm{C}_{18}$. A amostra foi eluída utilizando o gradiente linear dos solventes A $(0,1 \%$ de TFA em água) e B (90\% de Acetonitrila $+0,1 \%$ de TFA em água), sob um fluxo de $1 \mathrm{~mL} / \mathrm{min}$. As frações Fr 29 e Fr 32 (indicadas por setas), correspondem as cadeias polipeptídicas que constituem o inibidor. A Fr 28 ainda contém contaminantes (produtos da reação).

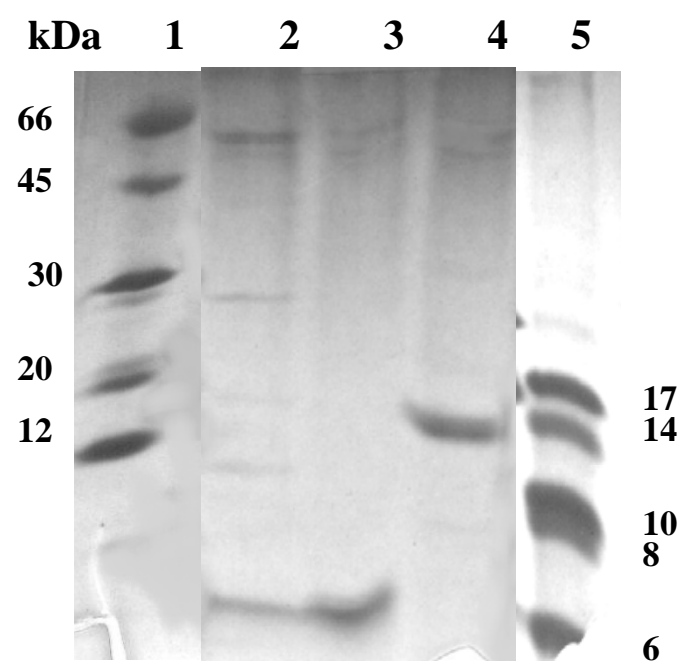

Figura 12 - SDS-PAGE das frações provenientes das reação de redução e alquilação das cadeias de ApTIB. O gel foi corado com Coomassie Blue R 250. Poços: (1) - Padrões de alto peso molecular; (2) Fração 28 (Fr28); (3) Fração 29 (Fr 29); (4) Fração 32 (Fr 32); (5) - Padrões de baixo peso molecular. 


\section{2.5 - Determinação das proteínas totais do extrato bruto e} quantificação dos inibidores

Partindo-se de $2 \mathrm{~g}$ do pó das sementes de A. plumosa, foram obtidos $17 \mathrm{~mL}$ de EB após centrifugação, separação do sobrenadante e processo de diálise. Esta quantidade apresentava uma massa de proteínas totais de $130 \mathrm{mg}$ (o que representa um conteúdo por volta de $6,5 \%$ de proteínas nas sementes de A. plumosa). O conteúdo protéico das sementes de leguminosas, de um modo geral, é altamente rico, chegando a representar cerca de $7-10 \%$ da massa total da semente.

Dentro destas proteínas totais, cerca de $8.5 \mathrm{mg}$ correspondem aos inibidores em estudo neste trabalho (o que representa uma fração de 6,5\% das proteínas totais de A.plumosa), distribuídos na forma de $2 \mathrm{mg}$ correspondentes à fração denominada ApTIA, $2 \mathrm{mg}$ à fração ApTIB, $3.5 \mathrm{mg}$ à fração ApTIC e $1 \mathrm{mg}$ à fração ApTID. Em virtude do baixo rendimento da isoforma D, alguns ensaios físico químicos e estruturais que requeriam uma maior quantidade dos inibidores purificados foram realizados somente com as isoformas $\mathrm{A}, \mathrm{B}$ e C.

Em plantas, os inibidores de proteases são geralmente os constituintes majoritários de sementes e tecidos de reserva, representando até $15 \%$ das proteínas totais. A Tabela 2 mostra o rendimento dos inibidores de proteases purificados de plantas da família Leguminosae, como o de Enterolobium contortisiliquum, EcTI (Batista et al, 1996), de Archidendron ellipticum, AeTI (Bhattacharyya, et al, 2006) e de Bauhinia variegata de duas variedades: candida e lilac, BvcTI e BvlTI, respectivamente (Ciero et al, 1998). Um papel de defesa contra predadores é a eles atribuído, uma vez que a concentração de inibidores de proteases necessário para o controle proteolítico intracelular é altamente excedida (Richarson, 1991). 


\begin{tabular}{||c||c||}
\hline Inibidor & Rendimento (\%) \\
\hline \hline ApTI & 6.5 \\
\hline EcTI & 12 \\
\hline BvcTI & 4.1 \\
\hline BvlTI & 8.5 \\
\hline AeTI & 8.0 \\
\hline
\end{tabular}

Tabela 2 - Rendimento de inibidores de protease pertencentes à família Leguminosae

III. 3 - Análise físico-química e estrutural das isoformas dos inibidores

\section{3.1 - Determinação do Ponto Isoelétrico}

O ensaio de focalização isoelétrica com ApPIII, e com os inibidores ApTIA, ApTIB está mostrada na Figura 13. A presença de isoinibidores na fração ApPIII é confirmada devido a presença de mais de uma banda no seu respectivo poço, contendo proteínas com pI por volta de 5.05, 5.25 e 5.55. O ensaio realizado com a fração ApTIA (poço 3), indica que a banda em 5.05 é referente à sua contribuição, do mesmo modo, no ensaio com ApTIB (poço 4) indica seu pI em 5.25. Desta forma, o inibidor ApTIC tem seu pI por volta de 5.55. Esta característica ácida no valor do pI destes inibidores é uma característica de inibidores de proteases do tipo Kunitz como o SbTI (pI 4.55), isoformas de inibidores de Bauhinia variegata (pIs 4.85; 5.0 e 5.15) e isoformas de Archidendron ellipticum (4.1, 4.55, 5.27 e 5.65). 


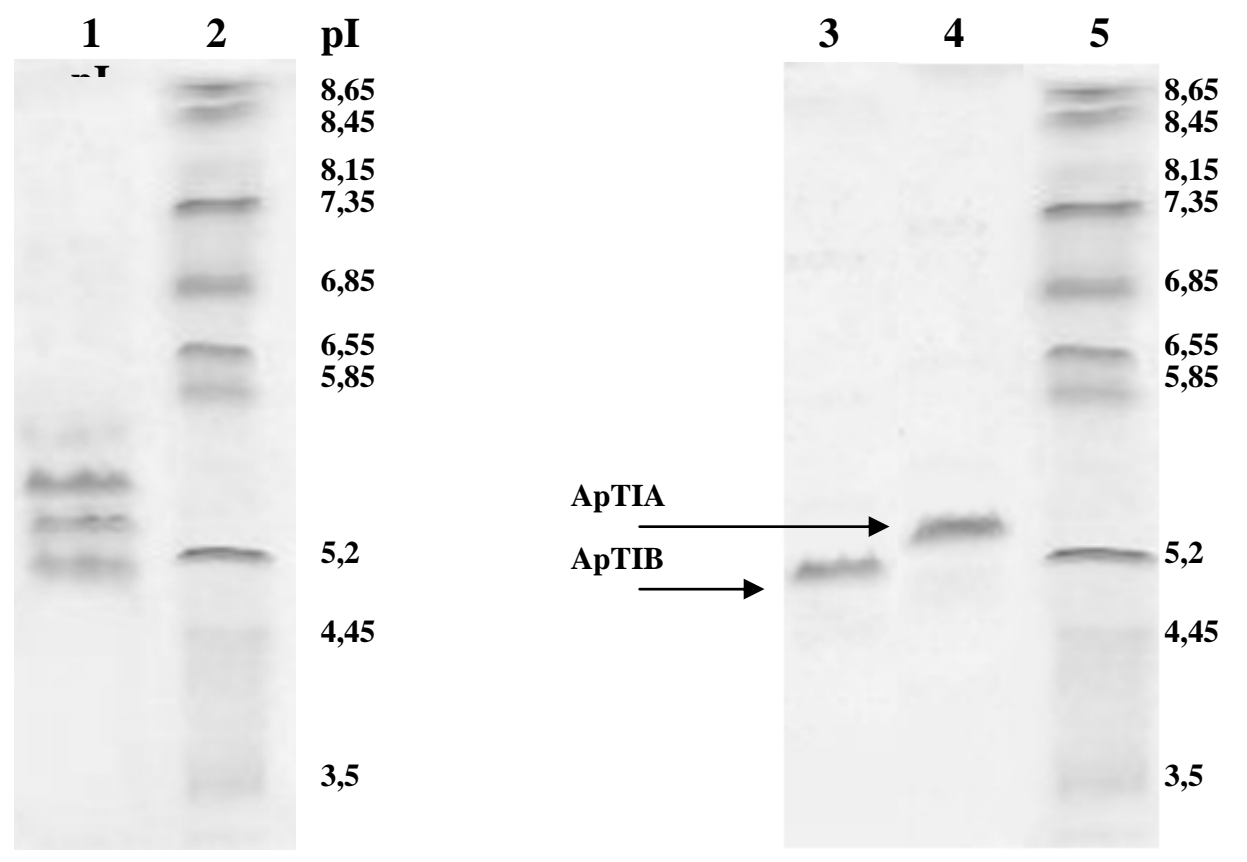

Figura 13 - Ensaio de focalização isoelétrica de ApPIII e dos inibidores de Acacia plumosa. O ensaio foi realizado no PhastSystem gel numa faixa de $\mathrm{pH}$ de 9,0 a 3,0. Poços: (1) ApPIII; (2) Padrões; (3) ApTIA; (4) ApTIB; (5) Padrões.

\section{3.2 - Formação do complexo enzima-inibidor}

O perfil de eluição do complexo formado pela incubação de cada um dos inibidores de A. plumosa com tripisina numa razão molar (1:3) está mostrado na Figura 14. Nesta figura, estão destacadas duas frações: o primeiro pico (Pico 1), que corresponde à eluição de moléculas que possuem massa molecular por volta de $50 \mathrm{kDa}$ e o segundo pico (Pico 2), que corresponde à eluição de moléculas que possuem massa molecular por volta de $25 \mathrm{kDa}$.

Considerando a estequiometria enzima-inibidor 1:1, o complexo tripsinainibidor apresentaria massa molecular por volta de $44 \mathrm{kDa}$; já com a 
estequiometria 2:1, a massa molecular esperada seria por volta de $68 \mathrm{kDa}$. Desta forma, à fração Pico 1 corresponde à eluição do complexo enzima inibidor, cuja estequiometria é 1:1; já a fração Pico 2 corresponde à tripsina em excesso na incubação (massa molecular por volta de $24 \mathrm{kDa}$ ).

A estequiometria observada no complexo enzima-inibidor formado, está de acordo com os dados encontrados na literatura para inibidores do tipo Kunitz (Macedo et al, 2000; Mello et al, 2002)
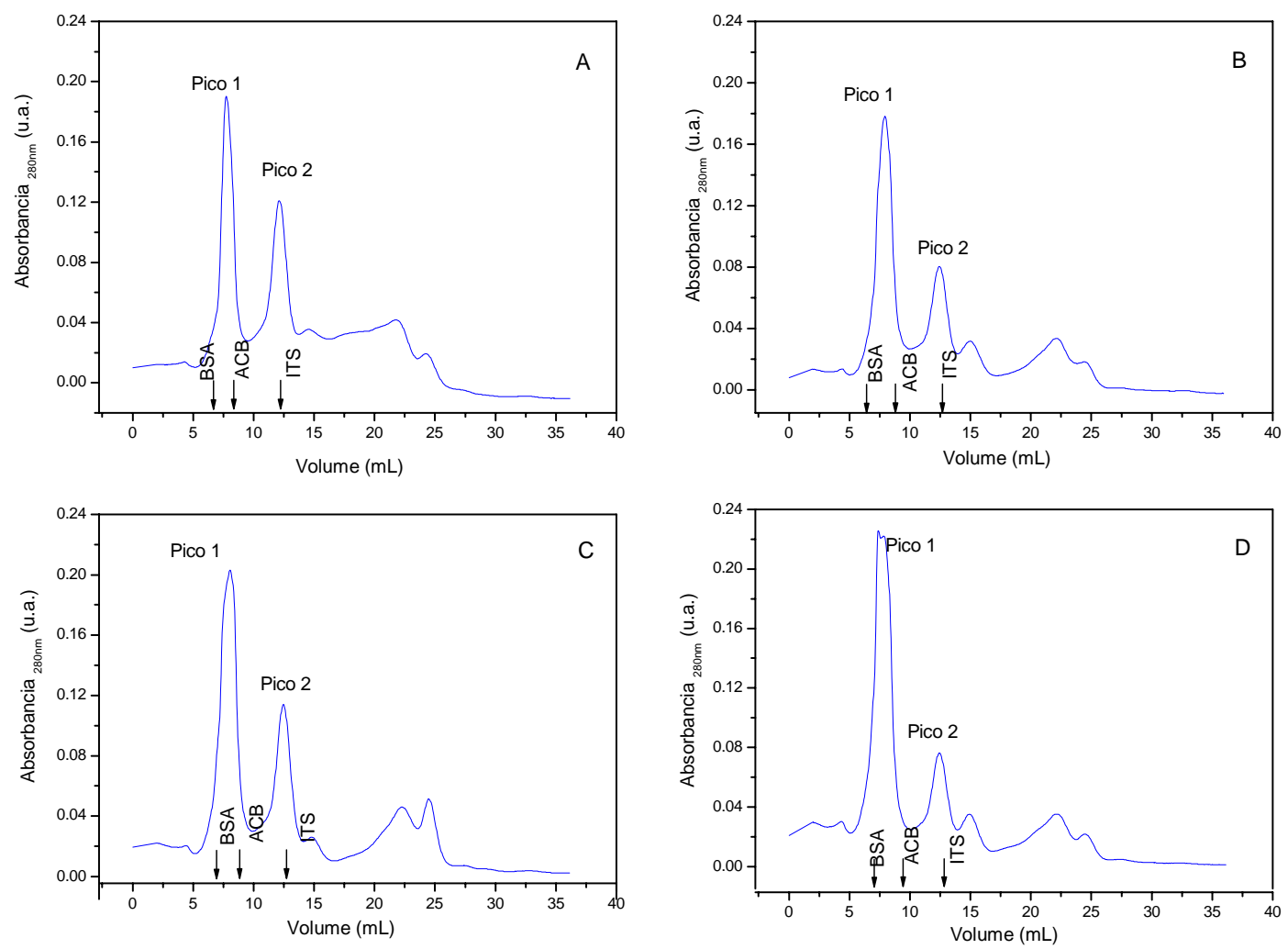

Figura 14 - Eluição do complexo enzima-inibidor em Superdex-75. A coluna foi previamente equilibrada e eluída com PBS pH 7.4. Todos os inibidores foram incubados por 30 minutos com tripsina, a $37^{\circ} \mathrm{C}$. As frações denominadas Pico 1 correspondem ao complexo tripsina-inibidor formado. As frações denominadas Pico 2 correspondem a tripsina na forma livre (excesso molar). Mostrando em: (A) o perfil de ApTIA, (B) o perfil de ApTIB, (C) o perfil de ApTIC e (D), o perfil de ApTID. 


\section{III.3.2.1 - Determinação de $K_{A}$ e $K_{D}$ do complexo}

\section{III.3.2.1.1 - Ensaio com tripsina}

A imobilização da tripsina no sensorchip CM5 ocorreu de forma eficiente, resultando num ganho em RU de 1480 unidades. Prosseguimos, então com os ensaios de cinética, para monitorar a interação de cada um dos inibidores (ApTIA, ApTIB e ApTIC) com a enzima tripsina imobilizada no chip. Os sensorgramas dos ensaios realizados estão mostrados na Figura 15.

Os três inibidores de A. plumosa formaram complexos muito estáveis com tripsina: os altos valores das constantes de associação $\left(\mathrm{K}_{\mathrm{A}}\right)$ dos inibidores com tripsina $\left(2.57,1.79\right.$ e $1.79 \times 10^{9} \mathrm{M}^{-1}$ para ApTI A, B e C, respectivamente), refletem a alta afinidade do sítio catalítico do ligante (enzima) para reconhecer e se ligar aos analitos (inibidores de A.plumosa). Já, os baixos valores das constantes de dissociação $\left(\mathrm{K}_{\mathrm{D}}\right)$ do complexo enzima-inibidor, por volta de $0,5 \mathrm{nM}$, indicam que o complexo formado é muito estável, sua taxa de decaimento é muito lenta $\left(\sim 10^{-5}\right.$ $\mathrm{s}^{-1}$ ), o que indica a alta potência dos inibidores de A.plumosa para inibir a ação da tripsina.

De acordo com os sensorgramas da Figura 15, foram calculadas as constantes de associação e de dissociação para cada um dos inibidores interagindo com tripsina, os valores estão na Tabela 3.

\begin{tabular}{||c||c|c|c|c||}
\hline \hline Inibidores & $\mathbf{k}_{\mathbf{a}}\left(\mathbf{1 0}^{\mathbf{5}} \mathbf{M}^{\mathbf{- 1}} \mathbf{s}^{\mathbf{- 1}}\right)$ & $\left.\mathbf{k}_{\mathbf{d}} \mathbf{( 1 0}^{-\mathbf{5}} \mathbf{s}^{\mathbf{- 1}}\right)$ & $\mathbf{K}_{\mathbf{A}} \mathbf{( \mathbf { 1 0 } ^ { \mathbf { 9 } } \mathbf { M } ^ { \mathbf { - 1 } } )}$ & $\left.\mathbf{K}_{\mathbf{D}} \mathbf{( n M}\right)$ \\
\hline \hline ApTIA & 1,68 & 6,53 & 2,57 & 0,389 \\
\hline ApTIB & 1,32 & 7,37 & 1,79 & 0,558 \\
\hline ApTIC & 1,54 & 8,58 & 1,79 & 0,557 \\
\hline
\end{tabular}

Tabela 3: Constantes de interação dos inibidores de A.plumosa com tripsina calculadas com o software BiaEvaluation. 

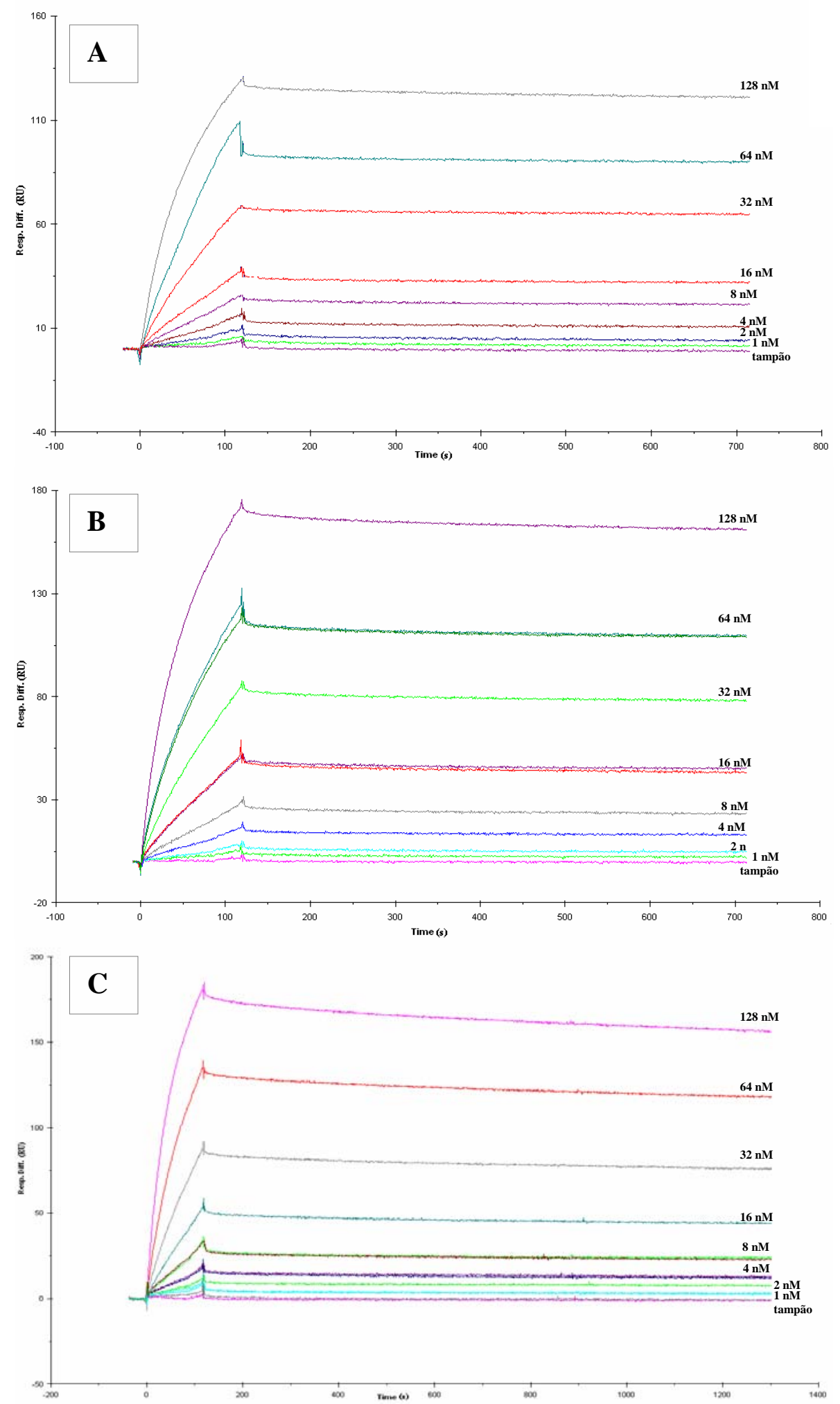

Figura 15 - Sensorgramas da interação de ApTIA, ApTIB e ApTIC com tripsina. Os inibidores ApTIA (em A), ApTIB (em B) e ApTIC (em C) foram injetados sobre tripsina imobilizada numa concentração de 1 a 128 nM. As medidas foram tomadas em tampão HBS-EP ( $\mathrm{pH}$ 7.4), a temperatura ambiente. 


\section{III.3.2.1.2 - Ensaio com quimotripsina}

A imobilização da quimotripsina no sensorchip CM5 pela técnica do acoplamento amina também se deu de forma eficiente. Dos ensaios de cinética com cada um dos inibidores (ApTIA, ApTIB e ApTIC) no sensorchip contendo a quimotripsina imobilizada, foram obtidos os sensorgramas mostrados na Figura 16. A partir destes dados, as constantes de associação e de dissociação destes inibidores com quimotripsina foram obtidas e estão na Tabela 4.

Os valores de $\mathrm{K}_{\mathrm{A}}\left(1.34,1.45\right.$ e $2,88 \times 10^{8} \mathrm{M}^{-1}$, para as isoformas $\mathrm{A}$, B e C, respectivamente) refletem uma menor afinidade na ligação do analito ao sítio catalítico da quimotripsina quando comparado com os valores obtidos para a tripsina (cerca de 20 vezes menos para a isoforma $A$; 12 vezes para $B$, e 6 para $C$ ). Além disso, os valores de $\mathrm{k}_{\mathrm{d}}$ (da ordem de $10^{-4} \mathrm{~s}^{-1}$ ), indicam que a taxa de decaimento do complexo é uma ordem de grandeza maior do que o decaimento do complexo formado com tripsina, o que reflete a sua menor estabilidade.

Este ensaio indica a interação dos três isoinibidores de A. plumosa com a da tripsina é mais eficiente, com a formação de um complexo mais estável, capaz de induzir uma inibição da ação da enzima mais potente do que quando comparado com a interação com a quimotripsina.

\begin{tabular}{||c||c|c|c|c||}
\hline \hline Inibidores & $\mathbf{k}_{\mathbf{a}}\left(\mathbf{1 0}^{\mathbf{4}} \mathbf{M}^{\mathbf{- 1}} \mathbf{s}^{\mathbf{- 1}}\right)$ & $\left.\mathbf{k}_{\mathbf{d}} \mathbf{( 1 0}^{\mathbf{4}} \mathbf{s}^{\mathbf{- 1}}\right)$ & $\left.\mathbf{K}_{\mathbf{A}} \mathbf{( 1 0}^{\mathbf{8}} \mathbf{M}^{\mathbf{- 1}}\right)$ & $\left.\mathbf{K}_{\mathbf{D}} \mathbf{( n M}\right)$ \\
\hline \hline ApTIA & 8,96 & 6,68 & 1,34 & 7,46 \\
\hline ApTIB & 10,3 & 7,11 & 1,45 & 6,89 \\
\hline ApTIC & 7,63 & 2,65 & 2,88 & 3,47 \\
\hline
\end{tabular}

Tabela 4 - Constantes de interação dos inibidores de A.plumosa com quimotripsina calculadas com o software BiaEvaluation. 


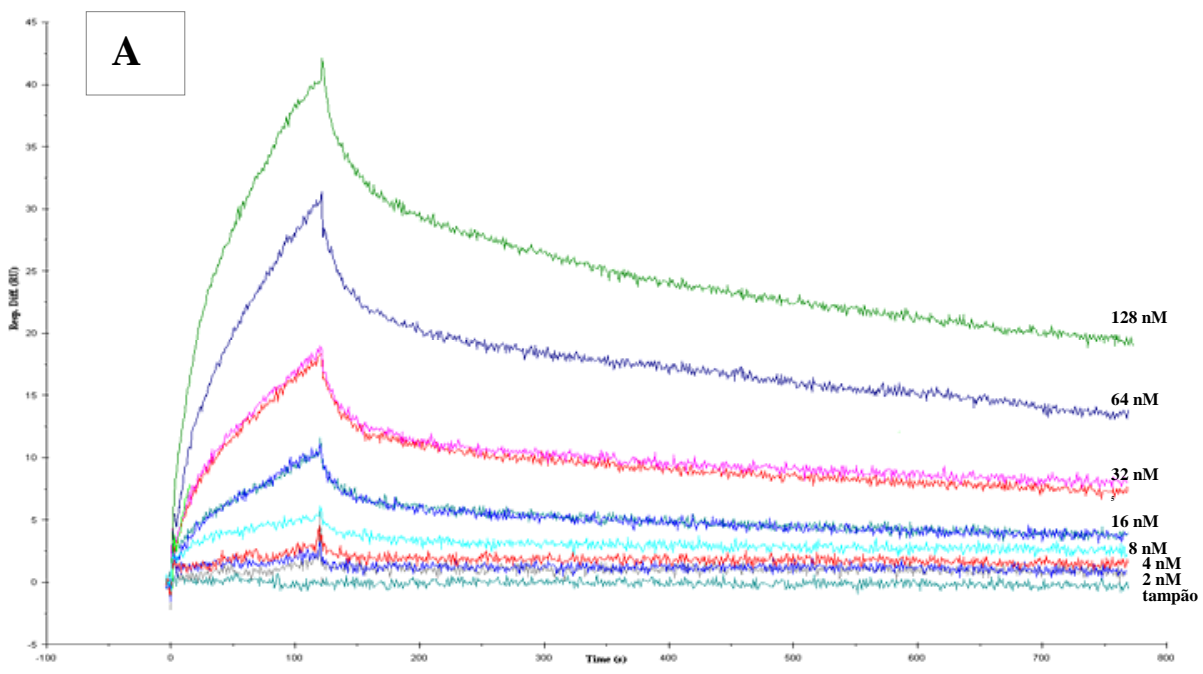

B

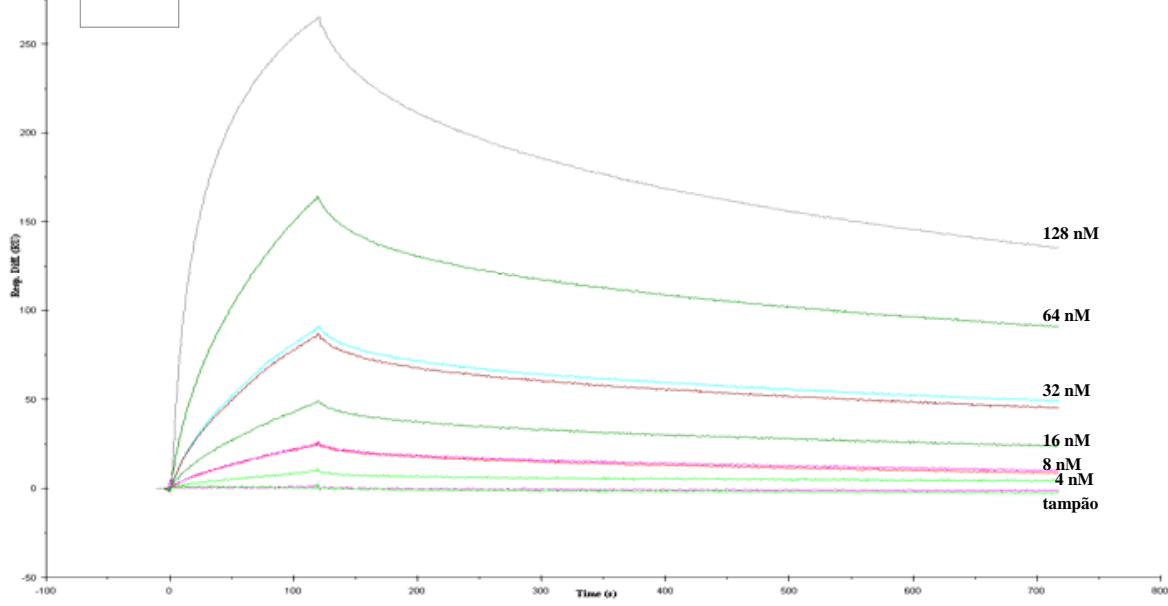

C

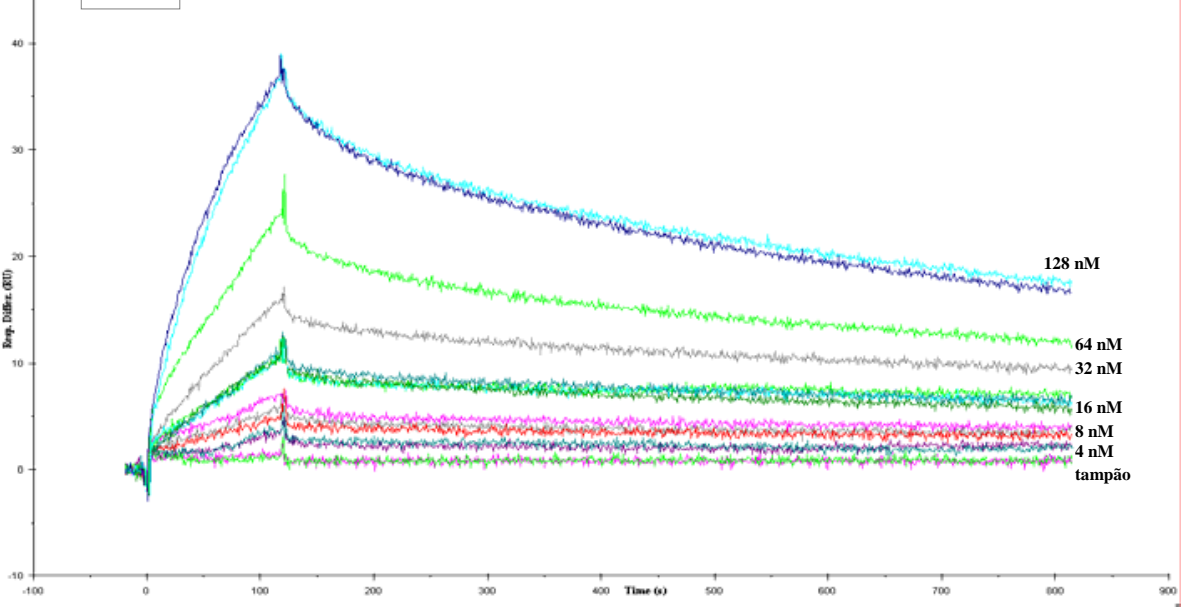

Figura 16 - Sensorgramas da interação de ApTIA, ApTIB e ApTIC com quimotripsina. Os inibidores ApTIA (em A), ApTIB (em B) e ApTIC (em C) foram injetados sobre tripsina imobilizada numa concentração de 0 a $128 \mathrm{nM}$. As medidas foram tomadas em tampão HBS-EP ( $\mathrm{pH} 7.4$ ), a temperatura ambiente. 
Na Figura 17, estão sobrepostos o sensorgrama da interação do inibidor ApTIA (numa concentração de $64 \mathrm{nM}$ ) com tripsina juntamente com o sensorgrama da interação do inibidor com quimotripsina. Nota-se o decaimento mais rápido (cerca de 20 vezes mais veloz) do complexo quimotripsina-ApTIA do que o complexo tripsina-ApTIA. O mesmo acontece para os demais isoformas.

Os baixos valores da constante de dissociação $\mathrm{K}_{\mathrm{D}}$ do complexo resultante tanto para a tripsina como para a quimotripsina (da ordem de $10^{-10}$ e $10^{-9} \mathrm{M}$, respectivamente) sugerem uma inibição potente dessas duas serinoproteases promovida pelos isoinibidores do arranha-gato.

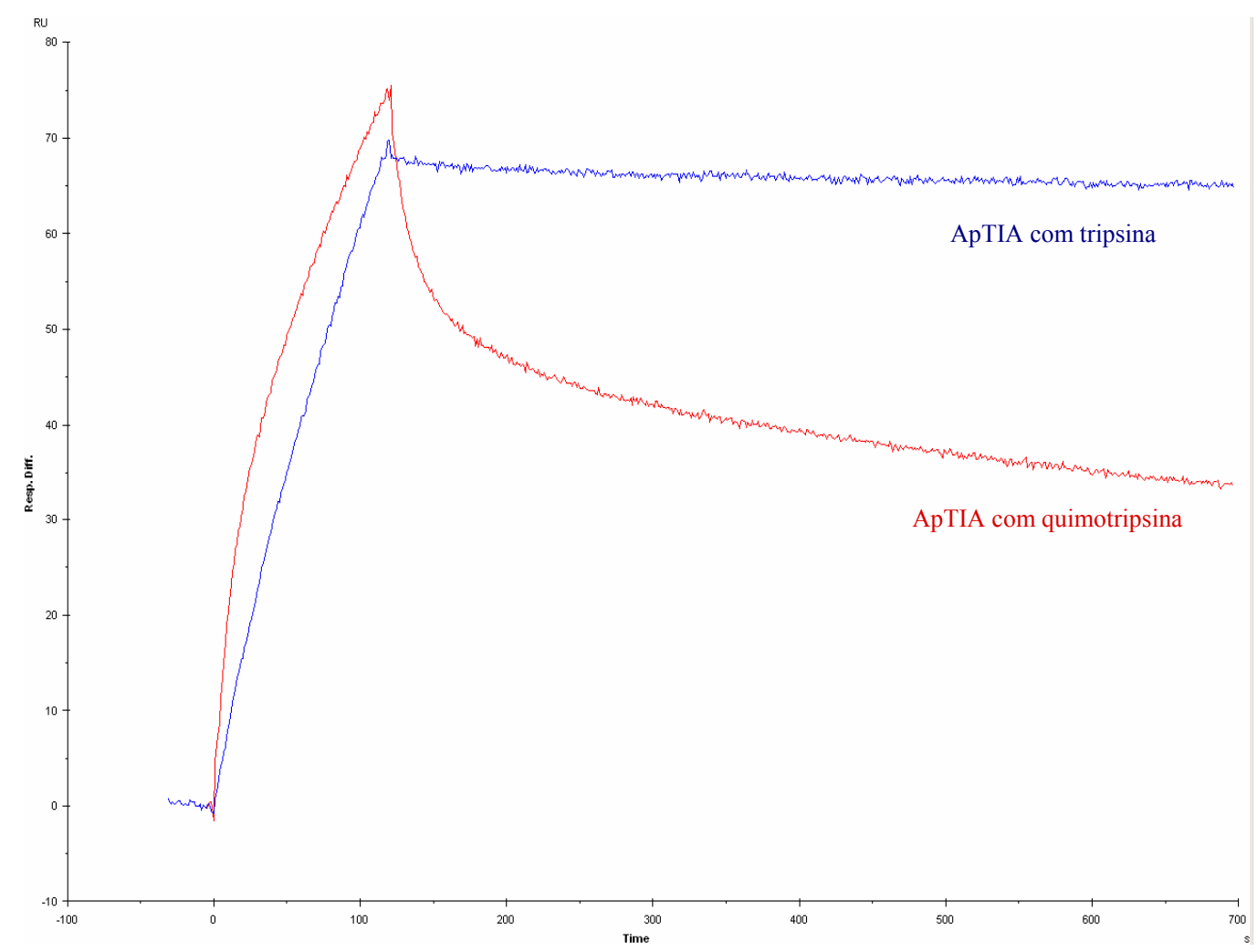

Figura 17 - Sensorgramas da interação de ApTIA com tripsina e com quimotripsina. As curvas correspondem a isoforma ApTIA numa concentração de 64 nM. A curva em azul corresponde à interação com tripsina, e a curva em vermelho corresponde à interação com quimotripsina. As medidas foram tomadas em tampão HBS-EP (pH 7.4), a temperatura ambiente. 


\section{3.3 - Determinação da Seqüência N-Terminal}

Para serem submetidas à análise do N-terminal, as amostras dos inibidores foram reduzidas, alquiladas, cromatografadas em sistema HPLC, e por fim cada uma das cadeias foi submetida à degradação de Edmann. O sequenciamento obtido está mostrado na Figura 18.

ApTIA

chain A: KELLVDNEGE

chain B: SDDKDFGILQ

ApTIB

chain A: KELLVDNEGEI

chain B: SDDSKDEGIE

ApTIC

chain A: KELLDIDGEI

chain B: KDDKVLGISQ

Figura 18 - Seqüência N-Terminal das três isoformas de inibidores de proteases de A. plumosa. Os aminoácidos foram determinados pela degradação de Edmann automatizada.

Os dez primeiros resíduos de aminoácidos da cadeia A dos três isoinibidores apresentam alta identidade seqüencial entre si. Os resíduo da cadeia A de ApTIA e ApTIB são idênticos, e em ApTIC, as diferenças são a ausência de um resíduo de Val (na posição 5 dos demais inibidores) e a substituição de uma Asn para uma Ile (na posição 7 dos demais inibidores). 
A cadeia $\mathrm{B}$ dos três isoinibidores também apresenta claramente resíduos conservados nas isoformas, mas é a cadeia em que ocorre uma maior variabilidade estrutural.

A busca por identidade seqüencial resultou no encontro de inibidores de protease do tipo Kunitz, tais como Leucaena leucocephala trypsin inhibitor (L1TI), Silktree inhibitor, Prosopis juliflora trypsin inhibitor (PjTI). Para prosseguirmos com o alinhamento seqüencial entre os inibidores já estruturalmente conhecidos com os inibidores de A. plumosa em estudo, utilizamos também a seqüência de dois inibidores de protease isolados do gênero Acacia, são eles AeTI (Acacia elata trypsin inhibitor) e AcTI (Acacia confusa trypsin inhibitor). O alinhamento das regiões N-terminal das duas cadeias dos inibidores está na Figura 19.

cadeia $\alpha\left[\begin{array}{ll}\text { AcTI } & \text { KELL-DADGDI } \\ \text { AeTI } & \text { KGLL-EAEGEI } \\ \text { LITI } & \text { GVL-VDLDGDP } \\ \text { PjTI } & \text { GELL-DVDGEI } \\ \text { ApTIA } & \text { KELLVDNEGE- } \\ \text { ApTIB } & \text { KELLVDNEGEI } \\ \text { ApTIC } & \text { KELL-DIDGEI }\end{array}\right.$

cadeia $\beta\left[\begin{array}{cc}\text { PjTI } & \text { SD-RCKDLGISI } \\ \text { ACTI } & \text { DDESCKDLGISI } \\ \text { Silktree } & \text { KDDHCKDLG-SI } \\ \text { ApTIA } & \text { SDD--KDFGILQ } \\ \text { ApTIB } & \text { SDDS-KDEGI-E } \\ \text { ApTIC } & \text { KDD--KVLGISQ } \\ \end{array}\right.$

Figura 19 - Alinhamento seqüencial múltiplo da região $\mathrm{N}$-Terminal dos inibidores de A.plumosa. No alinhamento, realizado com o programa CLUSTAL $X$, foram utilizadas as seqüências $N$-terminal das cadeias $\alpha$ e $\beta$ de inibidores de serinoproteases (LITI, PjTI, AeTI, AcTI e Silktree). Resíduos em vermelho representam resíduos conservados e similares, resíduos em azul representam resíduos presentes na maioria dos inibidores. 


\section{3.4 - Espectrometria de Massas}

análise por espectrometria de massa da fração denominada ApPIII foi realizada pela técnica de ionização de elétron-spray. Uma série de íons com razões massa/carga diferentes foram gerados na análise com ApPIII, conforme mostrado na Figura 20. Após os procedimentos de desconvolução, notamos um pico centrado em 19709 Da que representa a massa molecular com alta precisão de uma das isoformas de ApPIII. A presença de isoformas nesta fração foi evidenciada pela presença de outros picos com massas moleculares muito próximas ao pico de maior intensidade: um por volta de 19869 Da e outro em 20378 Da.

A digestão da fração denominada ApPIII (após redução e alquilação) com tripsina foi realizada gerando peptídeos de várias massas diferentes que puderam ser determinadas pela espectrometria de massas, conforme mostrado na Figura 21.

Um grande número de peptídeos foram detectados no digesto tríptico de ApPIII. Os picos mais intensos representam peptídeos de massa moleculares de $943.8,1202.8,1358.8,1474.8,1534.0,1609.9,1628.1$ e 1656.1 Da. A busca em base de dados de espectrometria de massa, como por exemplo, a Base de Dados Mascot (do site: www.matrixscience.com), por proteínas que após digestão com tripsina gerassem peptídeos com tais massas moleculares poderia nos fornecer a seqüência dos resíduos de aminoácidos de cada um dos picos detectados. No entanto, a taxa de identificação de proteínas de plantas é muita pequena, uma vez que o número de proteínas de plantas catalogadas em bases de dados para espectrometria de massas é muito baixo, com exceção para as espécies de Arabdopsis thaliana e Oryza sativa. Desta forma, a nossa busca não convergiu 
para proteínas da classe de inibidores de proteases; e as proteínas encontradas apresentavam um score fora da faixa confiável (até $27 \%$ ).

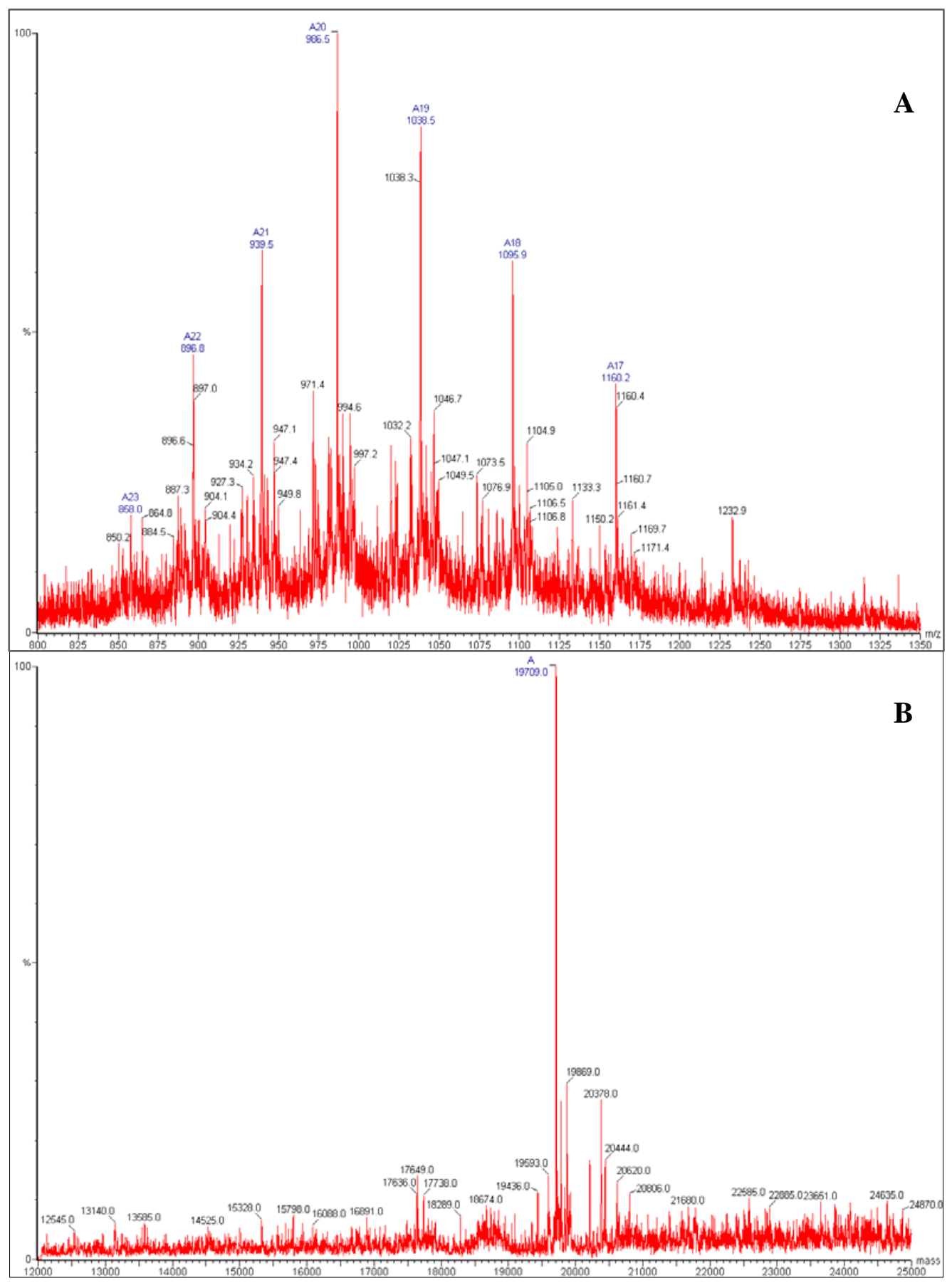

Figura 20 - Determinação da massa molecular de ApPIII, por ESI-MS, em condições nativas. O peso molecular foi obtido após desconvolução usando MaxEnt1 de uma série de íons em forma de envelope (em A) e resultou numa $\mathrm{Mr}$ $19709 \mathrm{Da}$, e isoformas em 19869 e $20378 \mathrm{Da}$ (em B). 


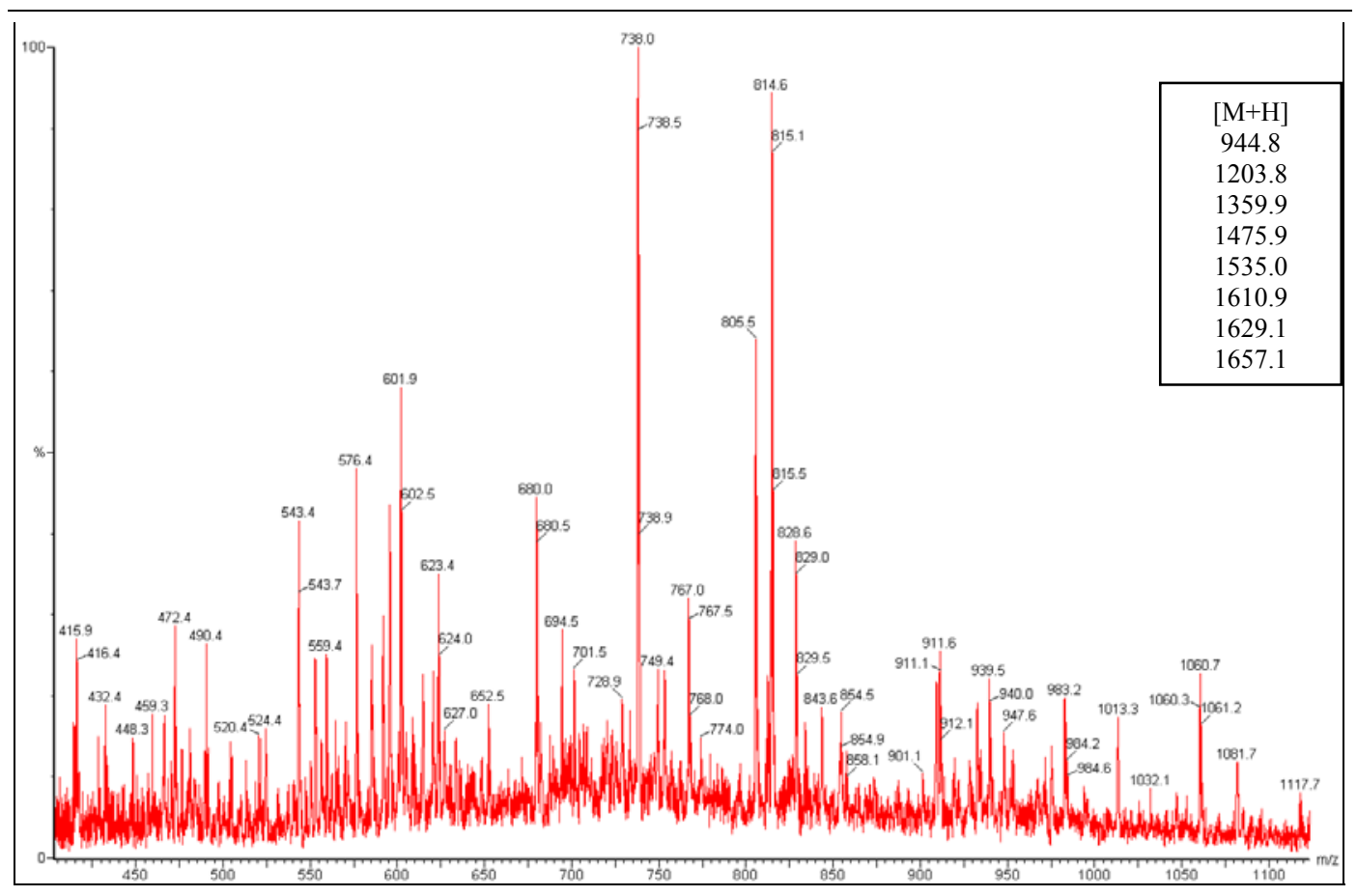

Figura 21 - Peptide Mass Fingerprint de ApPIII (reduzida e alquilada) obtida por ESI-MS. As massas inseridas representam os íons mais intensos no espectro dos peptídeos trípticos após desconvolução das cargas por Maxent3 (masslynx v.3.3, Micromass, Manchester, UK).

O seqüenciamento de dois peptídeos internos identificados como pep1 e pep2 de ApPIII de massas 1609.9 e 1358.8, respectivamente, foi realizada pela espectrometria de massa, revelando as seguintes seqüências:

\section{pep1: QTSYYLLSSAAR \\ pep2 XXDESWFNTLFHR}

A busca por similaridade com regiões internas de inibidores de proteases do tipo Kunitz já identificados, revelou identidades com: STI (Soybean Trypsin 
inhibitor), AcTI e L1TI. A Figura 22 mostra o alinhamento de tais seqüências, feito com o auxílio do programa CLUSTAL X.
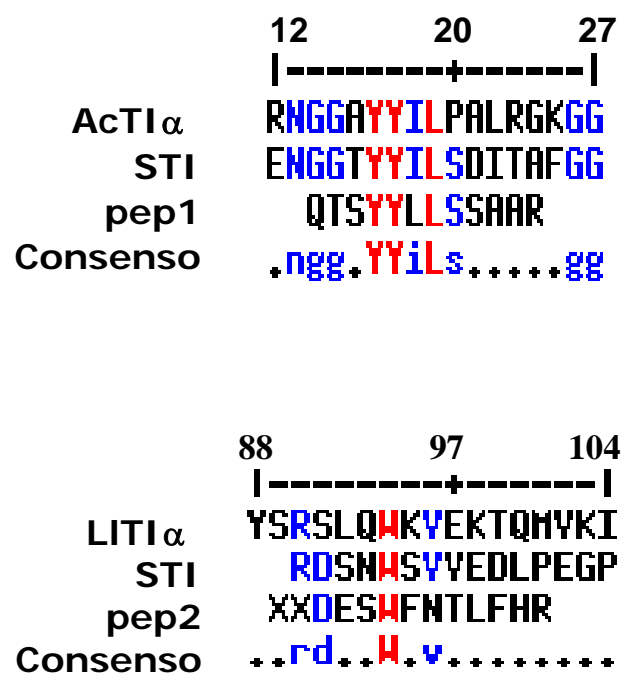

Figura 22 - Alinhamento seqüencial de peptídeos da região interna de ApPIII com outros inibidores de serinoproteases. $\mathrm{O}$ alinhamento foi realizado com $\mathrm{o}$ programa CLUSTAL X. Resíduos em vermelho representam resíduos conservados em todos os inibidores, resíduos em azul representam resíduos idênticos na maioria dos inibidores.

III. 3.5 - Espectroscopia de dicroísmo circular (CD) e cálculo do conteúdo das frações de estrutura secundária

Os espectros de CD no UV distante das quatro frações ApTIA, ApTIB, ApTIC e ApTID em PBS (pH 7.4) em temperatura ambiente, mostrado na Figura 23, são caracterizados pela presença de duas bandas: uma positiva e mais fraca em torno de $230 \mathrm{~nm}$ e uma banda negativa mais intensa centrada em $202 \mathrm{~nm}$. Esta 
última banda é descrita na literatura como contribuição majoritária da alta presença de estrutura não-ordenada, enquanto que o sinal em $230 \mathrm{~nm}$ pode ser atribuído tanto às cadeias laterais dos aminoácidos aromáticos, como também aos elementos em conformações desordenadas, além da contribuição de pontes S-S (Woody, 1978; Sreerama \& Woody, 2003).

Mais uma vez os dados estão de acordo com a estrutura de outros inibidores de proteases do tipo Kunitz, cujo conteúdo estrutural ocorre a predominância de fitas- $\beta$ e elementos não ordenados.

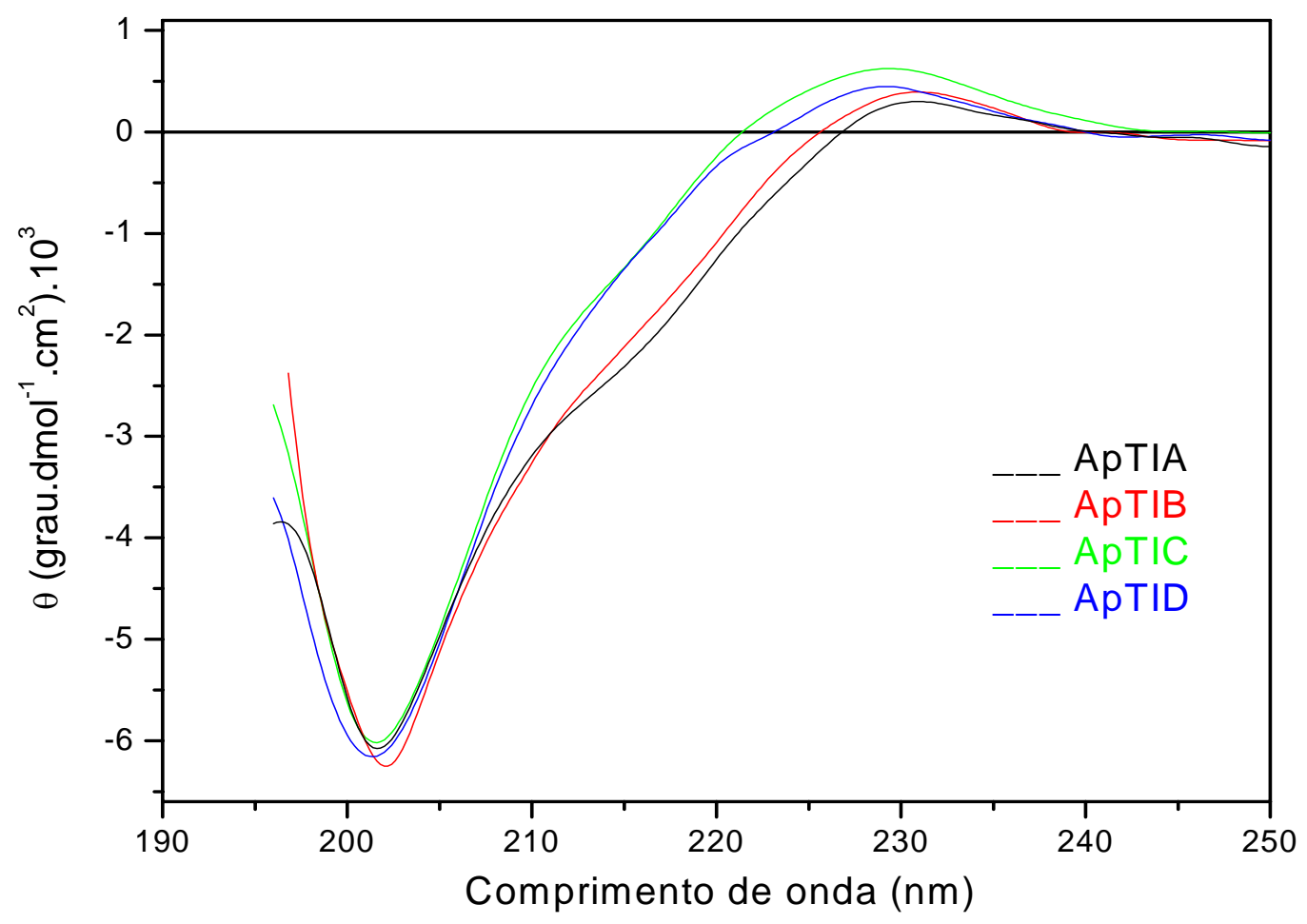

Figura 23 - Espectro de CD dos inibidores de protease de A.plumosa. Os espectros foram tomados numa cubeta cilíndrica de caminho óptico de $1 \mathrm{~mm}$, a temperatura ambiente. 
As frações de estrutura secundária dos inibidores, mostradas na Tabela 5, foram determinadas com o uso dos três programas de desconvolução do pacote CDPro (Selcon3, Continll e CDSSTR). Os quatro inibidores são predominantemente constituídos de elementos em estruturas- $\beta$ ( $42 \%$ em média) e de elementos em estrutura não-ordenada (por volta de 32\%).

\begin{tabular}{|c|c|c|c|c|c|}
\hline \multicolumn{7}{|c|}{ ApTIA } \\
\hline \hline Programa & $\alpha$-hélice(\%) & fita- $\beta(\%)$ & voltas (\%) & desordenada(\%) & RMS(\%) \\
\hline \hline Selcon3 & 5 & 46 & 19 & 30 & 3 \\
\hline Contin11 & 4 & 41 & 23 & 32 & 1 \\
\hline CDSSTR & 3 & 35 & 27 & 35 & 2 \\
\hline \hline Média & 4 & $\mathbf{4 1}$ & $\mathbf{2 3}$ & $\mathbf{3 2}$ & \\
\hline
\end{tabular}

\begin{tabular}{||c|c|c|c|c|c|}
\hline \multicolumn{7}{|c|}{ ApTIB } \\
\hline \hline Programa & $\alpha$-hélice(\%) & fita- $\beta(\%)$ & voltas (\%) & desordenada(\%) & RMS(\%) \\
\hline \hline Selcon3 & 7 & 44 & 18 & 31 & 4 \\
\hline Contin11 & 5 & 42 & 21 & 32 & 1 \\
\hline \hline Média & 3 & 39 & 25 & 33 & 2 \\
\hline \hline
\end{tabular}

\begin{tabular}{|c|c|c|c|c|c|}
\hline \multicolumn{7}{|c|}{ ApTIC } \\
\hline \hline Programa & $\alpha$-hélice(\%) & fita- $\beta(\%)$ & voltas (\%) & desordenada(\%) & RMS(\%) \\
\hline \hline Selcon3 & 6 & 45 & 20 & 29 & 4 \\
\hline Continl1 & 5 & 42 & 21 & 32 & 1 \\
\hline CDSSTR & 2 & 43 & 22 & 33 & 2 \\
\hline \hline Média & $\mathbf{4}$ & $\mathbf{4 3}$ & $\mathbf{2 1}$ & $\mathbf{3 2}$ & \\
\hline
\end{tabular}

\begin{tabular}{|c|c|c|c|c|c|}
\hline \multicolumn{7}{|c|}{ ApTID } \\
\hline \hline Programa & $\alpha$-hélice(\%) & fita- $\beta(\%)$ & voltas (\%) & desordenada (\%) & RMS(\%) \\
\hline \hline Selcon3 & 5 & 41 & 20 & 34 & 3 \\
\hline Continll & 5 & 43 & 21 & 31 & 1 \\
\hline CDSSTR & 3 & 38 & 25 & 34 & 2 \\
\hline \hline Média & $\mathbf{4}$ & $\mathbf{4 1}$ & $\mathbf{2 2}$ & $\mathbf{3 3}$ & \\
\hline
\end{tabular}

Tabela 5 - Frações de estrutura secundária das isoformas dos inibidores de protease de A.plumosa calculadas com o pacote de desconvolução CDPro. 


\section{3.6 - Espectroscopia de fluorescência}

Os espectros de emissão de fluorescência com a excitação em 280 e 290 nm são muito semelhantes quanto ao posicionamento do máximo de emissão de suas bandas, conforme pode ser observado na Figura 24.

O máximo de emissão de fluorescência dos inibidores ApTIA, ApTIB e ApTIC está centrado em 340 nm, sugerindo a conservação da posição espacial dos resíduos aromáticos na estrutura tridimensional dos três inibidores. Além disso, o valor indica uma parcial exposição dos resíduos aromáticos ao solvente (ambiente polar).
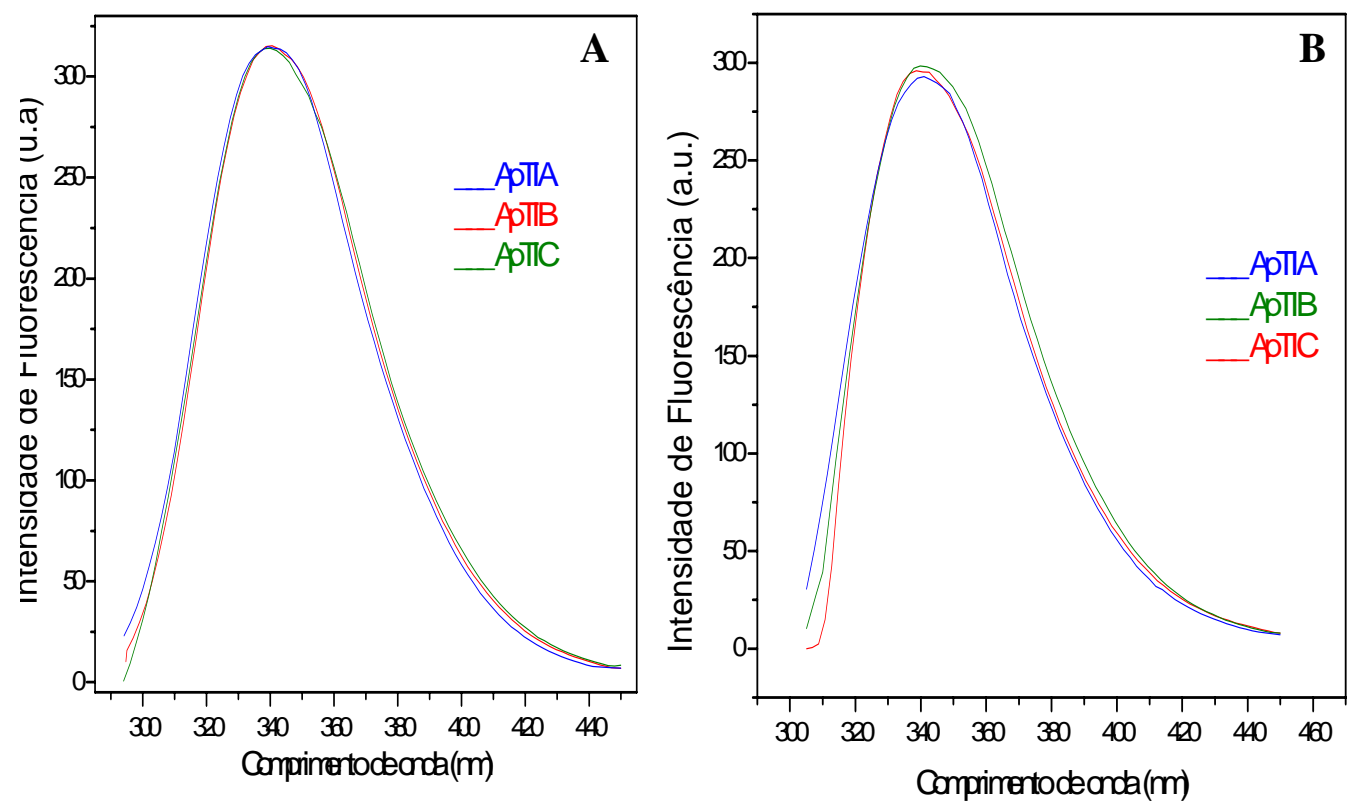

Figura 24 - Espectros de emissão de fluorescência dos inibidores de protease de A.plumosa. As amostras dos inibidores utilizados, a uma concentração de $0,7 \mathrm{mg} / \mathrm{mL}$, foram excitadas em $280 \mathrm{~nm}$, sendo monitorados de 295 a $450 \mathrm{~nm}(\mathrm{~A})$, e em $295 \mathrm{~nm}$, sendo monitorados de 305 a $450 \mathrm{~nm}$ (B). Os espectros de emissão foram tomados à temperatura ambiente. 


\section{III.3.7 - Ensaios de estabilidade frente a variações de pH}

A monitoração do ensaio de estabilidade dos inibidores frente a variações de $\mathrm{pH}$ tanto por CD como por fluorescência mostraram alta estabilidade em extremos ácido e básico de pH, Figuras 25 e 26

Como pode ser observado na Figura 25, a forma dos espectros de CD, em todo o intervalo de $\mathrm{pH}$ testado, é compatível com o espectro de CD do inibidor em condições fisiológicas (em PBS, pH 7.4). As discretas alterações consistem num pequeno deslocamento para o vermelho (red shift) da banda em $202 \mathrm{~nm}$, em pH 12,0. Estes resultados estão de acordo com o comportamento de outros inibidores de protease do tipo Kunitz descritos na literatura, como por exemplo, o inibidor isolado de Schizolobium parahyba (Teles et al, 2004).

Os espectros de emissão de fluorescência, Figura 26, mostram que a posição dos máximos de emissão $\left(\lambda_{\text {máx }}\right)$ permaneceu conservada em $340 \mathrm{~nm}$ em todo o intervalo de $\mathrm{pH}$ testado (de 2.0 a 12.0), sugerindo que a vizinhança dos aminoácidos aromáticos não sofreram alteração estrutural neste intervalo. Apenas um pequeno deslocamento de 340 para 341 nm é notado na posição do máximo de emissão dos inibidores ApTIA e ApTIB nos pH mais alcalinos (10,0 e 12,0).

A diminuicão da intensidade de fluorescência, chamada de supressão (quenching), é notada tanto nos pHs mais ácidos $(2,0$ e 4,0) como também nos pHs mais alcalinos $(10,0$ e 12,0), e pode ser explicada devido às cadeias laterais de alguns resíduos de aminoácidos tornam-se carregadas nesta faixa de $\mathrm{pH}$, passando então a competir com a emissão da fluorescência. 

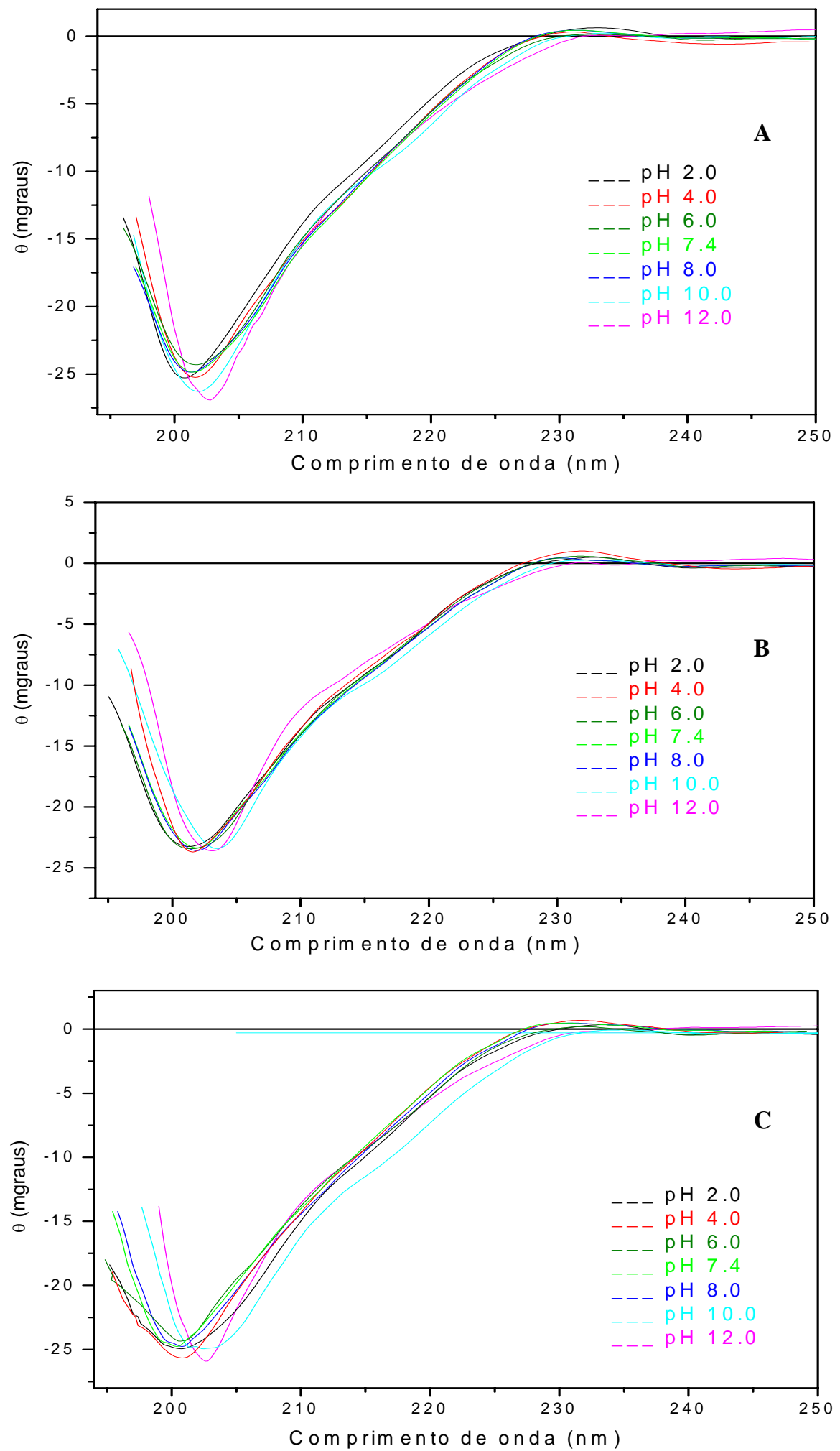

Figura 25 - Espectros de CD do ensaio de estabilidade frente a variações de pH. A concentração dos inibidores foi de $0,2 \mathrm{mg} / \mathrm{mL}$ Em (A), estão os espectros de ApTIA; (B), os espectros de ApTIB; e em (C), os espectros de ApTIC. Os espectros foram tomados numa cubeta cilíndrica de caminho óptico de $1 \mathrm{~mm}$, a temperatura ambiente. 

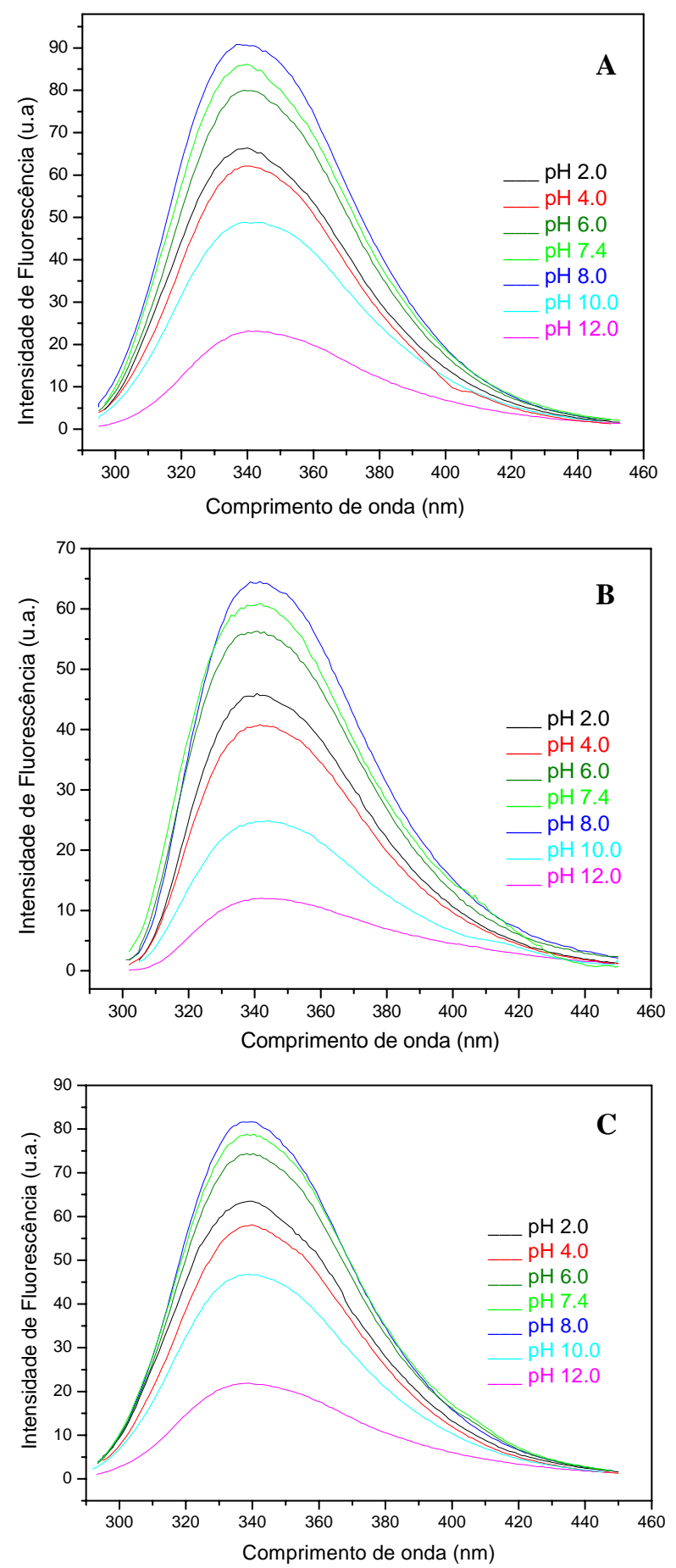

Figura 26 - Espectros de emissão de fluorescência do ensaio de estabilidade de pH. As amostras dos inibidores $(0,7 \mathrm{mg} / \mathrm{mL})$ após incubação por 24 horas em cada $\mathrm{pH}$ diferente, foram excitadas em $280 \mathrm{~nm}$ e seus espectros de emissão de fluorescência foram monitorados de 295 a $450 \mathrm{~nm}$. Em (A), estão os espectros de ApTIA; em (B), os espectros de ApTIB; e em (C), os espectros de ApTIC. As medidas foram tomadas a temperatura ambiente. 


\section{III.14 - Ensaios de estabilidade térmica}

Os espectros de $\mathrm{CD}$ tomados no ensaio de estabilidade térmica indicam que o os inibidores de protease de A. plumosa possuem uma estrutura rígida, muito estável termicamente, Figura 27. O início do estado desnaturado dos inibidores só foi alcançado para temperaturas acima de 60,65 e $60^{\circ} \mathrm{C}$ para ApTIA, ApTIB e ApTIC, respectivamente. Sendo que a temperatura em que $50 \%$ de cada uma das amostras se encontra no estado desnaturado e $50 \%$ se encontra no estado nativo foi, 75,74 e $75^{\circ} \mathrm{C}$, para ApTIA, ApTIB e ApTIC, respectivamente.

As alterações observadas devido ao aquecimento das amostras foram a perda do mínimo característico em $202 \mathrm{~nm}$ e da banda positiva em $230 \mathrm{~nm}$, passando a apresentar um espectro típico de proteína desnaturada.

As curvas mostradas na Figura 28 representam os dados do ensaio de estabilidade térmica, na qual o monitoramento da absorbância foi feito nos comprimentos de onda de 230 e $202 \mathrm{~nm}$. Elas representam as curvas de transição das mudanças estruturais sofridas pelos inibidores em função da temperatura, sugerindo que a passagem do estado nativo para o estado desnaturado dos isoinibidores de A.plumosa, seja regido por um processo de dois estados.

Após serem submetidas a $95^{\circ} \mathrm{C}$, as amostras foram resfriadas à temperatura ambiente, e novamente seus espectros de CD foram tomados, conforme mostrado na Figura 29. Desta vez, a perda das bandas características do espectro nativo indicou que as amostra encontravam-se desnaturadas após tratamento térmico. Em seguida, tais amostras foram submetidas aos ensaios de atividade biológica. No entanto, não foram detectadas as atividades de inibição da tripsina nem de inibição da coagulação para nenhuma das amostras empregadas neste ensaio, o que sugere que este processo de desnaturação térmica dos inibidores seja irreversível. 

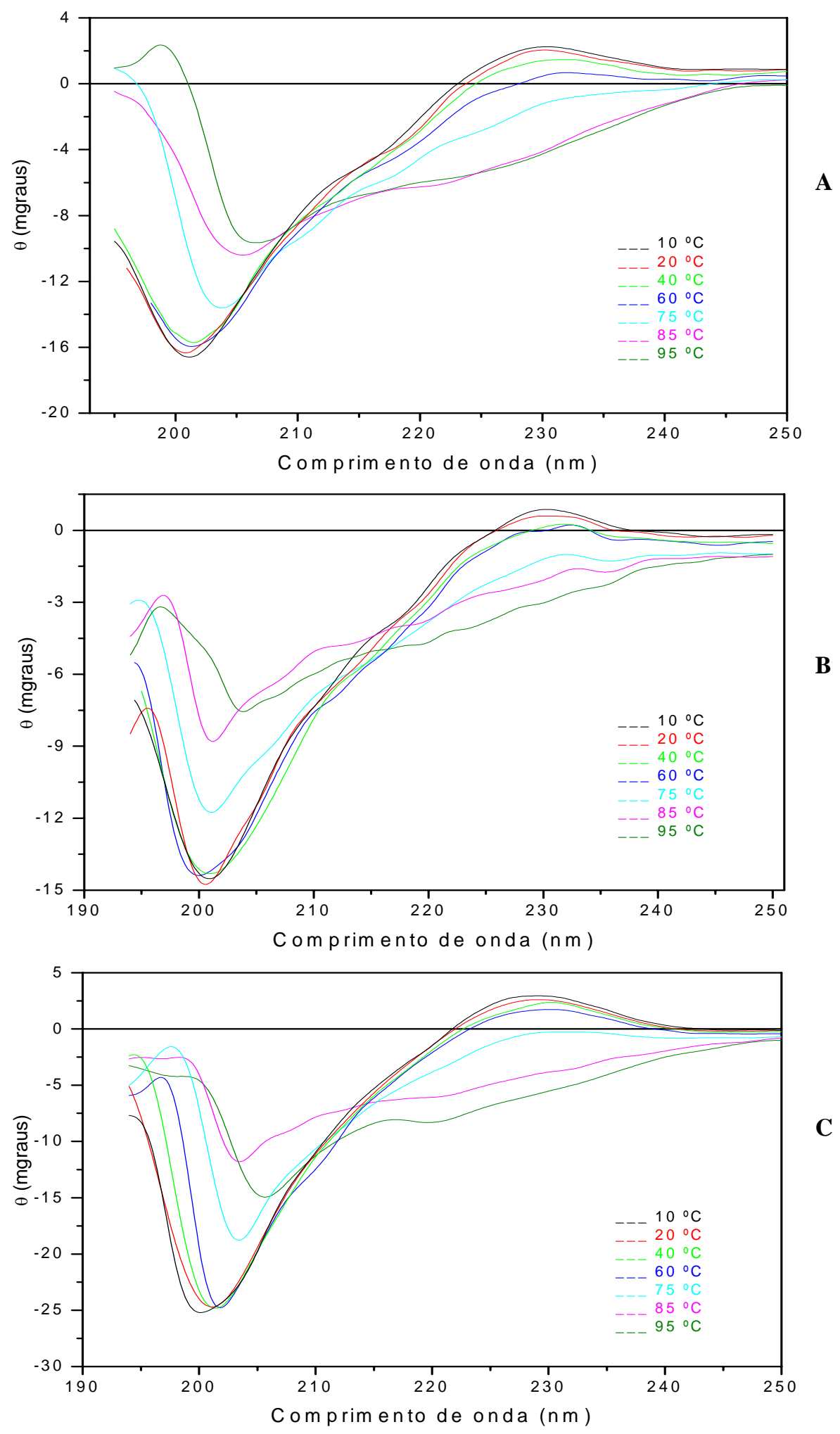

Figura 27 - Espectros de CD do ensaio de estabilidade térmica. Em (A) os espectros de ApTIA (0,22 mg/mL); em(B), ApTIB (0,2 mg/mL); e em (C) ApTIC $(0,3 \mathrm{mg} / \mathrm{mL})$. Todos os espectros foram tomados numa cubeta cilíndrica de caminho óptico de $1 \mathrm{~mm}$. 

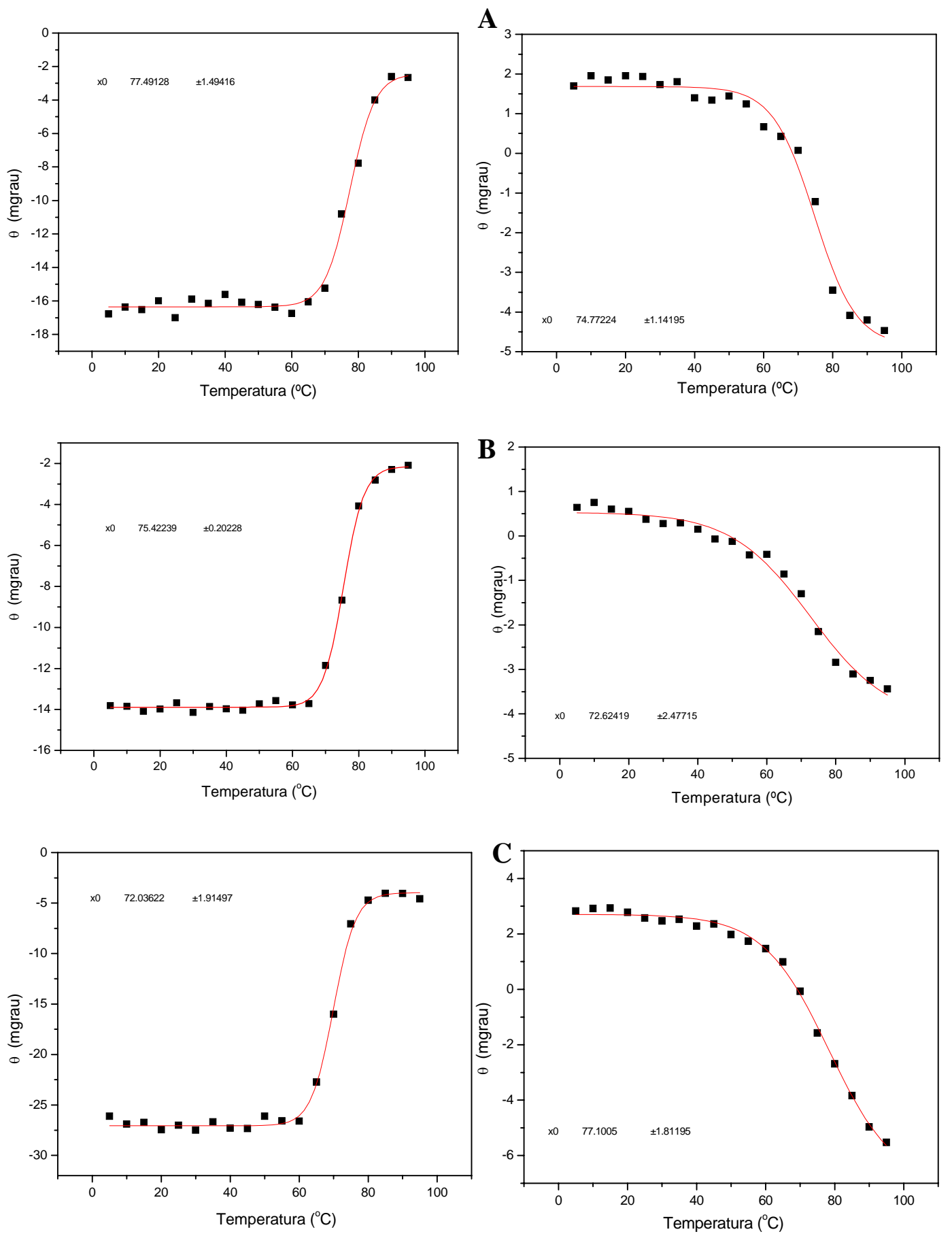

Figura 28 - Curvas de desnaturação térmica dos inibidores. As curvas a esquerda representam o monitoramento da banda em $202 \mathrm{~nm}$ do espectro de CD dos inibidores, já as da direita representam a banda em $230 \mathrm{~nm}$. Em A, mostrando aos espectros de ApTIA. Em B, os espectros de ApTIB. Em C, os espectros de ApTIC. Os espectros foram tomados numa cubeta cilíndrica de caminho óptico de $1 \mathrm{~mm}$, num intervalo de 5 a $95^{\circ} \mathrm{C}$, com os espectros tomados a cada $5^{\circ} \mathrm{C}$. 




Figura 29 - Espectros de CD de ApTIC antes e depois do ensaio de desnaturação térmica. ApTIC $(0,3 \mathrm{mg} / \mathrm{mL})$ em PBS. Os espectros foram tomados numa cubeta cilíndrica de caminho óptico de $1 \mathrm{~mm}$.

\section{III.15 - Atividade biológica}

\section{III.15.1 - Atividade anticoagulante}

A capacidade apresentada pelos inibidores de A.plumosa de afetar a cascata de coagulação sanguínea, e prolongar o tempo para a formação do coágulo, foi testada incubando cada um dos inibidores $(50 \mu \mathrm{g})$ com $50 \mu \mathrm{L}$ de plasma humano a $37^{\circ} \mathrm{C}$. Neste ensaio possível observar que ApTIA, ApTIB, ApTIC e ApTID são 
capazes de retardar o tempo de coagulação sanguínea por cerca de 9,5;10; 7 e 6,5 vezes, respectivamente, com base num controle (em qual o processo de coagulação aconteceu em vias normais em 4 minutos).

\begin{tabular}{||c||c||}
\hline \hline $\begin{array}{c}\text { Amostra } \\
\mathbf{( 5 0} \boldsymbol{\mu g})\end{array}$ & $\begin{array}{c}\text { Tempo para formação } \\
\text { do coágulo (min) }\end{array}$ \\
\hline \hline Controle & $3,9 \pm 0,4$ \\
ApTIA & $38 \pm 2$ \\
ApTIB & $40 \pm 1$ \\
ApTIC & $27 \pm 2$ \\
ApTID & $26 \pm 1$ \\
\hline \hline
\end{tabular}

Tabela 6 - Tempo de retardamento da coagulação sangǘnea dos inibidores de A.plumosa.

A diferença entre as especificidades deste isoinibidores é também evidenciada neste ensaio, pois alguma(s) enzima(s) envolvida(s) na cascata de coagulação sangüínea foi(foram) mais fortemente inibida(s) pelas isoformas A e B, o que explica o maior retardo no tempo de formação do coágulo (cerca de 1,5 vez maior do que para as isoformas C e D). Tal fato nos sugere que estamos diante de dois grupos de isoformas com características mais semelhantes entre si: o primeiro grupo das isoformas ApTIA e ApTIB, e o segundo é o das isoformas ApTIC e AptID. As características compartilhadas por esses dois grupos abrangem desde especificidade ao sítio catalítico de enzimas, como semelhança estrutural (notada pelas semelhanças nos espectros de CD destes dois grupos), hidrofobicidade (notada pela posição de eluição na cromatografia de fase reversa), distribuição de cargas na superfície da estrutura tridimensional (devido à eluição em coluna 
catiônica) e identidade seqüencial (identidade notada pela determinação dos primeiros resíduos de aminoácido da cadeia $\alpha$ destes inibidores).

\section{III.15.2 - Atividade de inibição de enzimas}

Amostras do EB de A.plumosa, da fração denominada ApPIII e de cada uma das isoformas dos inibidores mostraram-se capazes de inibir a ação da tripisina in vitro sobre o seu substrato sintético BAPNA. Este ensaio de caráter qualitativo também sugere a preservação da estrutura espacial dos inibidores durante o processo de purificação, permanecendo capaz de reconhecer e se ligar ao sítio catalítico da enzima.

Amostras dos inibidores ApTIA, ApTIB e ApTIC não mostraram atividade inibitória sobre a enzima carboxipeptidase A, uma representante das metaloproteases, o que sugere que os inibidores de A.plumosa sejam específicos para promoverem a inibição de enzimas da classe das serinoproteases.

\section{III.15.3 - Atividade sobre fungos fitopatogênicos}

O ensaio de atividade antifúngica em microplaca de 96 poços foi realizado com os fungos fitopatógenos Aspergillus niger, Colletotrichum sp. F37, Colletotrichum sp. P10, Fusarium moniliforme, Fusarium graminearum, Pyricularia sp, Hendersonina sp e Thielaviopsis paradoxa. Neste ensaio notou-se a inibição do crescimento fungíco nos esporos de Aspergillus niger, 
Colletotrichum sp e Thielaviopsis paradoxa, quando tais espécies foram incubados com uma quantidade de inibidor de 140, 140 e $70 \mu \mathrm{g} /$ poço, respectivamente, de acordo com a Figura 30.

Não foi notada a inibição do crescimento das espécies Colletotrichum sp. F37, Fusarium graminearum, Pyricularia sp e Hendersonina sp. Para o fungo Fusarium moniliforme, o crescimento foi inespecífico, gerando inibição do crescimento do fungo em alguns poços com menores quantidades do inibidor, e crescimento exagerado dos fungos em outras concentrações maiores do inibidor. Portanto para este fungo o ensaio deve ser repetido.



Figura 30 - Inibição do crescimento de fungos em microplaca de 96 poços. $\mathrm{O}$ teste foi realizado em duplicata com Aspergillus niger (A), Colletotrichum sp P.10. (B), Thielaviopsis paradoxa (C) e Fusarium moniliforme (D). Uma diluição seriada foi realizada com $140 \mu \mathrm{g}$ de ApPIII na direção da coluna 1 para a coluna 7, de modo que a quantidade de ApPIII em cada coluna foi de: 1- $140 \mu \mathrm{g}$; 2- $70 \mu \mathrm{g}$; 3- $35 \mu \mathrm{g}$; 4- $17 \mu \mathrm{g}$; 5- $8.0 \mu \mathrm{g}$; 6- $4.0 \mu \mathrm{g}$; 7- $2.0 \mu \mathrm{g}$; 8- Controle positivo (apenas esporos e meio BD). A incubação da solução de esporos no meio BD se deu por 6 dias. 
No ensaio realizado em placas de Petri, dentre as várias espécies de fungos utilizadas, observamos que os inibidores de A.plumosa foram capazes de promover a inibição do crescimento micelar das espécies de Aspergillus niger, Colletotrichum sp P.10 e Fusarium moniliforme. A inibição é notada devido à verificação de um acentuado crescimento do fungo em direção do controle (disco 3), e devido à formação de um pequeno halo de inibição do fungo em torno do disco de papel contendo a menor quantidade do inibidor (disco 2), e a formação e um halo de inibição maior em torno do disco contendo maior quantidade do inibidor (disco 1), conforme mostrado na Figura 31.

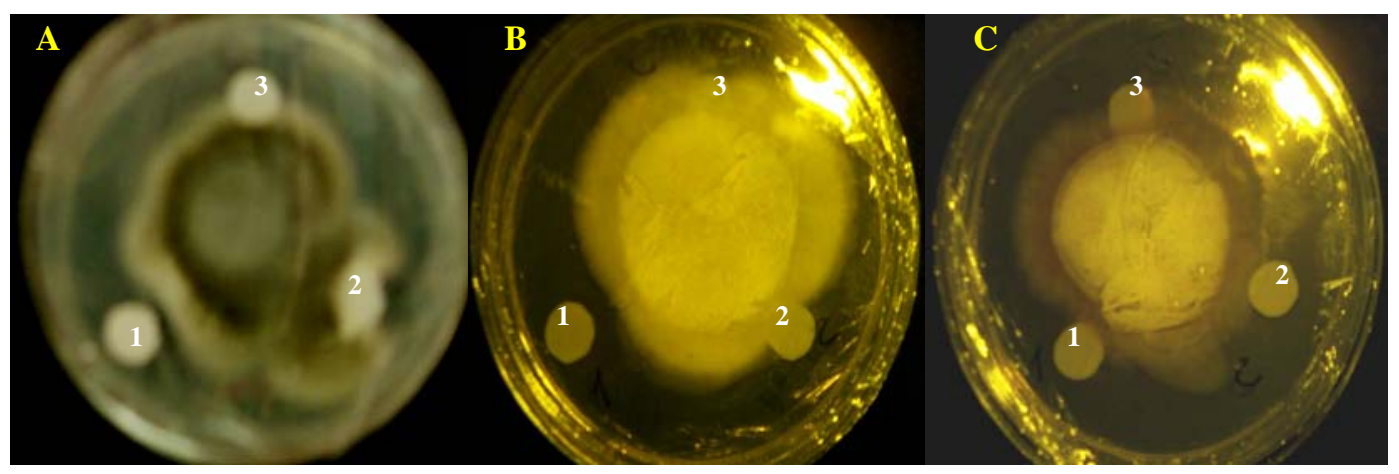

Figura 31 - Inibição do crescimento de fungos em placas de Petri. Os inibidores de A.plumosa mostraram capacidade de inibir o crescimento das cepas de Aspergillus niger (A), Colletotrichum sp P.10 (B) e Fusarium moniliforme (C). Os discos de papel estão identificados da seguinte maneira: 1 - $100 \mu \mathrm{g}$ do inibidor; 2 - $50 \mu \mathrm{g}$ do inibidor; 3 - controle (PBS).

Não foi observado a formação do halo de inibição do crescimento micelar do fungo para as seguintes espécies: Aspergillus chevalier, Aspergillus fumigatus, Botrytis cinerea, Colletotrichum gloeosporioides, Colletotrichum lindemuthianum, 
Colletotrichum musae, Colletotrichum sp. F37, Colletotrichum truncatum, Fusarium graminearum, Fusarium oxysporum, Fusarium pollidoroseum, Hendersnina sp, Lasiodiplodia theobromae, Mucor sp, Phomopsis sp, Pythium oligandrum, Rhizoctonia solani e Trichoderma viridae. 


\section{IV-CONCLUSÕES}

Neste trabalho, foram detectadas a presença de pelo menos quatro isoformas de inibidores de serinoproteases nas sementes da leguminosa Acacia plumosa. Tais isoformas, denominadas ApTIA, ApTIB, ApTIC e ApTID, foram purificadas e caracterizadas. O estudo das propriedades físico-químicas e estruturais dos inibidores de A.plumosa nos permitiu classifica-los como membros da família dos inibidores de serinoproteases do tipo Kunitz pois eles compartilham muitas características comuns com os outros membros deste grupo:

$\checkmark \quad$ Apresentam massas molecular por volta $20 \mathrm{kDa}(19709$; 19869 e $20378 \mathrm{Da})$;

$\checkmark \quad$ São constituidos por duas cadeias polipeptídicas unidas entre si por pontes dissulfeto: uma por volta de $15 \mathrm{kDa}$ e outra por volta de $5 \mathrm{kDa}$;

$\checkmark \quad$ Apresentam identidade seqüencial na região N-Terminal das duas cadeias com outros inibidores do tipo Kunitz;

$\checkmark \quad$ pI na faixa ácida (5.0, 5.25 e 5.55);

$\checkmark$ Apresentam estrutura secundária marcadamente composta de elementos em estruturas não-ordenadas (32\%) e fitas- $\beta$ (42\%); 
$\checkmark \quad$ Possuem estrutura secundária altamente estável a muitas condições desfavoráveis, tais como variações térmicas e variações de pH (inclusive a extremos pHs ácidos ou alcalinos);

$\checkmark \quad$ Forma complexos estáveis, sugerindo alto poder de inibição tanto para a tripsina como para a quimotripsina;

$\checkmark \quad$ Apresentam maior afinidade para se ligar ao sítio catalítico da tripsina, cerca de até 20 vezes maior; além de o complexo formado com quimotripsina apresentar uma maior taxa de dissociação (uma ordem de grandeza maior);

$\checkmark$ Pelos ensaios de atividade biológica, tais como atividade anticoagulante, inibição do crescimento de fungos e inibição de enzimas proteolíticas, verificou-se que os inibidores de A.plumosa são capazes de:

- interagir com enzima(s) envolvida(s) na cascata de coagulação sangüínea, prolongando significativamente o tempo de coagulação;

- inibir a ação de tripsina in vitro, e não possuir atividade inibitória sobre metaloproteases como a carboxipeptidase A;

- inibir o crescimento dos fungos fitopatógenos: Aspergillus niger, Colletotrichum sp P10 e Thielaviopsis paradoxa, e ainda apresentar atividade inibitória sobre Fusarium moniliforme; 


\section{$\underline{\mathrm{V} \text { - PERSPECTIVAS }}$}

O prosseguimento do trabalho com os inibidores de proteases de Acacia .plumosa pode objetivar as seguintes tarefas:

$\checkmark$ Obtenção da seqüência primária completa de ApTIA, ApTIB, ApTIC e ApTID, que poderá esclarecer as pequenas variações na especificidade destes inibidores junto às enzimas proteolíticas, além de revelar seus graus de identidade com as demais inibidores do tipo Kunitz;

$\checkmark$ Ensaios de inibição de enzimas proteolíticas (calicreína, elastase, plasmina, tripsina e quimotripsina) com o intuito de se calcular a constante de inibição para cada uma dessas enzimas;

$\checkmark$ Ensaios de SPR, com a imobilização de outras enzimas proteolíticas no sensorchip CM5, a fim de verificar a afinidade destes inibidores pelo sítio catalítico de outras enzimas e a estabilidade do complexo formado;

$\checkmark$ Determinação dos parâmetros termodinâmicos ( $\Delta \mathrm{H}, \Delta \mathrm{G}, \Delta \mathrm{S}, \quad \Delta \mathrm{Cp})$ envolvidos na interação destes inibidores com as mesmas enzimas proteolíticas, por ensaios de calorimetria, num microcalorímetro VP-ITC Microcal;

$\checkmark$ Realização de ensaios de cristalização dos inibidores, e uma vez obtidos cristais, utilizar-se da difração de raios-X para resolver suas estruturas tridimensionais. 


\section{VI - REFERÊNCIAS BIBLIOGRÁFICAS}

ALTSCHUL, S.F.; GISH, W.; MILLER, W.; MYERS, E.W.; LIPMAN, D.J. Basic local alignment search tool. J. Mol. Biol. V. 215. p. 403-410. (1990).

ANTÃO, C.M., MALCATA, F.X. Plant serine proteases: biochemical, physiological and molecular features. Plant Physiology and Biochemistry. v. 43. p. 637-650. (2005).

ARAÚJO, A.P.U.; HANSEN, D.; VIEIRA, D.F.; OLIVEIRA, C.; SANTANA, L.A.; BELTRAMINI, L.M.; SAMPAIO, C.A.M.; OLIVA, M.L.V. Kunitz-type Bauhinia bauhinioides inhibitors devoid of disulfide bridges: isolation of the cDNAs, heterologous expression and structural studies. Biol. Chem. v.386. p. 561-568. (2005).

ARIAS, M.E.; GOMEZ, J.D.; CUDMANI, N.M.; VATTUONE, M.A.; ISLA, M.I. Antibacterial activity of ethanolic and aqueous extracts of Acacia aroma Gill. ex Hook et Arn. Life Sciences v. 75. p.191-202. (2004).

ASMS, The American Society for Mass Spectrometry. What is Mass Spectrometry? 3.ed. Edt. Tech. Graphics. Los Catos, CA. 25p. (1998).

ASZTALOS, B.F.; SCHAEFER, E.J.; HORVATH, K.V.; C.E.; COX, SKINNER, S.; GERRIOR, J.; GORBACH, S.L.; WANKE, C. Protease inhibitor-based HAART, HDL, and CHD-risk in HIV-infected patients. Atherosclerosis. v. 184 (1). p. 72-77. (2006).

BARRETT, A.J,; RAWLINGS, N.D. Evolutionary lines of cysteine peptidases. Biol Chem., v. 382 (5). p. 727-733. (2001). 
BATISTA, I.F.C.; OLIVA, M.L.V.; ARAUJO, M.S.; SAMPAIO, M.U.; RICHARDSON, M.; FRITZ, H.; SAMPAIO, C.A.M. Primary structure of a Kunitztype trypsin inhibitor from Enterolobium contortisiliquum seeds. Phytochemistry, v. 41 (4). p. 1017-1022. (1996).

BHATTACHARYYA, A.; MAZUMDAR, S.; LEIGHTON, S.M.; BABU, C.R. A Kunitz proteinase inhibitor from Archidendron ellipticum seeds: Purification, characterization, and kinetic properties. Phytochemistry, v. 67. (3). p. 232-241 (2006).

BIACORE AB, Biacore X Booklet. Getting Started. Editor October 2002. Edition October. Version AA. 52p. (2002).

BIRK, Y. The Bowman-Birk inhibitor, Tripsin and chymotrypsin-inhibitor form soybeans. Int. J. Protein Res. v. 25. p241-252. (2000).

BODE, W., HUBER, R. Structural basis of the endoproteinase-protein inhibitor interaction. Biochimica et Biophysica Acta. v. 1477. p.241-252. (2000).

BREITENEDER H.; RADAUER C. A classification of plant food allergens. Journal of Allergy and Clinical Immunology. v. 113 (5). p. 821-830. (2004).

BROADWAY, R.M.; VILLANI, M.G. Does host range influence susceptibility of herbivorous insects to novel plant proteinase inhibitors? Entomol. Exp. Appl. v.76. p. 303-312. (1995).

BRONSE, G.J.; GIRARD, T.J.; NOVOTNY, W.F. Regulation of coagulation by a multivalent Kunitz-type inhibitor. Biochemistry. v. 29. p.7539-7546. (1990).

CAMPBEL, I.D.; DWEK, R.A. Biological Spectroscopy. Benjamin Cummings Publish Co. Inc. (1984). 
CARLINI, C.R.; GROSSI-DE-SA, M.F. Plant toxic proteins with insecticidal properties. A review on their potentialities as bioinsecticides. Toxicon, v. 40. p. 1515-1539. (2002).

CHOU K.C.; CAI, Y.D. Prediction of protease types in a hybridization space. Biochemical and Biophysical Research Communications, v. 339 (3). p. 1015-1020. (2006).

CIERO, L.D.; OLIVA, M.L.V.; TORQUATO, R.; KOHLER, P.; WEDER, J.K.P.; NOVELLO, J.C.; SAMPAIO, C.A.M.; OLIVEIRA, B.; MARANGONI, S. The complete amino acid sequence of a trypsin inhibitor from Bauhinia variegata var. candida seeds. Phytochemistry. v. 41. (4). p. 1017-1022. (1996).

COOPER, J.B. Aspartic proteinases in disease: a structural perspective. Current Drug Targets. v. 3. p. 155-173. (2002).

DECLERK, Y.A. Interactions between tumor cells and stromal cells and proteolytic modification of the extracellular matrix by metalloproteinases in cancer. European Journal of Cancer. v. 36. p. 1258-1268. (2000).

GETTINS, P.W. Serpin Structure, Mechanism, and Function. Chem. Rev., v. 102. p. 4751 - 4804. (2002)

GRZONKA, Z.; et al. Structural studies of cysteine proteases and their inhibitors. Acta Biochimica Polonica. v. 48 (1). (2001).

GUZMÁN-PARTIDA, A.M.; ROBLES-BURGUEÑO, M.R.; ORTEGA-NIEBLAS, M.; VÁZQUEZ-MORENO, I. Purification and characterization of complex carbohydrate specific isolectins from wild legume seeds: Acacia constricta is (vinorama) highly homologous to Phaseolus vulgaris lectins. Biochimie. v. 86 (4-5). p. 335-342. (2004). 
HAQ, S.K.; ATIF, S.M.; KHAN, R.H. Protein proteinase inhibitor genes in combat against insects, pests and pathogens: natural and engineered phytoprojection. Archives of Biochemistry and Biophysics. v. 431 (1). p. 145-159. (2004).

HEDSTROM, L. Serine Protease Mechanism and Specificity. Chem. Rev., v. 102. p. 4501 - 4524. (2002).

HIGGINS, D.G.; SHARP, P.M. CLUSTAL: a package for performing multiple sequence alignment on a microcomputer. Gene, v. 73 (1). p. 237-244. (1988).

HUNG, C.H.; LEE, M.C.; LIN, J.Y. Inactivation of Acacia confuse trypsin inhibitor by site-specific mutagenesis. Letters v. 353. p. 312-314. (1994)

HUNG, C.H.; LEE, M.C.; LIN, M.T.; LIN, J.Y. Clonning and expression of the gene encodind Acacia confusa trypsin inhibitor that is active without post-translational proteolysis. Gene. v. 127. p. 215-219. (1993).

JOHNSON et al. Analysis of Protein Circular Dichroism Spectra for secondary structures using a simple matrix. Multiplication, Anal. Biochem. v. 155. p. 155-167. (1986).

JOUBERT, F.J. Purification and properties oh the proteinase inhibitors from Acacia sieberana (paperback Acacia) seed. Phytochemistry. v.22. p. 53-57. (1983).

KEIDERLING, et al. Systematic comparison of statistical analysis of electronic and vibrational circular dichroism for secondary structure prediction of selected proteins. Biochemistry. v. 30. p. 6885-6895. (1991).

KELLY, S.M., PRICE, N.C. The application of circular dichroism to studies of protein folding and unfolding; Biochim. Biophys. Acta. v. 1338. p. 161-185. (1997).

KORTT, A.A.; JERMYN, M.A. Acacia proteinase inhibitors. Eur. J. Biochem. v. 115. p. 551-557. (1981). 
LAKOWICZ, J. R. Principles of Fluorescence Spectroscopy. Edt. Plenum Publishers. 2.ed. New York. (1999).

LASKOWSKI Jr, M.; KATO, I. Protein inhibitors of proteinases. Annual Review of Biochemistry. v. 49. p. 685-693. (1980).

LASKOWSKI Jr, M.; QASIM, M.A. What can the structures of enzyme-inhibitor complexes tell us about the structures of enzyme substrat complexes? Biochimica et Biophysica Acta. v. 1477. p. 324-337. (2000).

LAWRENCE, P.K.. KOUDAL, K.R. Plant protease inhibitors in control of phytophagous insects. Eletronic Journal of Biotechnology (EJB). v.5 (1). p.93-109. (2002).

LIN, J.Y.; CHU, S.C.; WU, H.C.; HSIEH, Y.S. Trypsin inhibitor from the seeds of Acacia confusa. J. Biochem. v. 110. p. 879-883. (1991).

LORENZI, H. Plantas daninhas do Brasil: terrestres, aquáticas, parasitas e tóxicas. 3. ed. Nova Odessa, SP. (2000).

LOWRY, O.H.; ROSEBROUGH, N.J.; FARR, A.L.; RANDALL, R.J. Protein measurement with the Folin Phenol reagent. J. Biol. Chem. v. 193 (1). p. 265-275. (1951).

MACEDO, M.L.R.; MATOS, D.G.; MACHADO, O.L.T.; NOVELLO, J.C. Trypsin inhibitor from Dimorphandra mollis seeds: purification and properties. Phytochemistry. v. 54. p. 553-558. (2000).

MELLO, G.C.; OLIVA, M.L.V.; SUMIKAWAW, J.T.; MACHADO, O.L.T.; MARANGONI, S.; NOVELlo, J.C.; MACEDO, M.L.R. Purification and characterization of new trypsin inhibitor from Dimorphandra mollis seeds. Journal of Protein Chemistry. v. 20. p. 625-632. (2002). 
MORRISON, S.C.; SAVAGE, G.P.; MORTON, J.D.; RUSSELL, A.C. Identification and stability of trypsin inhibitor isoforms in pea (Pisum sativum L.) cultivars grown in New Zealand. Food Chemistry. In Press. Corrected Proof. (2005).

NAKANISHI, K; BEROVA, N. WOODY, R.W. Circular Dichroism - Principles and Applications. Edt. VCH. (1994).

NETO, J.G.A.B. Deconvolução de padrões isotopoméricos obtidos de espectros de massa de baixa resolução para obtenção de padrões isotópicos elementares. São Paulo, 2002. 176p. Tese (Doutorado) - Instituto de Química, Universidade de São Paulo.

NEURATH, H. The regulation of protease action: An Overview. In: AVILES, F.X. ed. Innovations in proteases and their inhibitors. Berlin, de Gruyter, 3-12.

OLIVA, M.L.V.; ANDRADE, S.; BATISTA, I.F.C.; SAMPAIO, M.U.; JULIANO, M.; FRITZ, H.; AUERSWALD, E.A.; SAMPAIO, C.A.M. Human plasma kallikrein and tissue kallikrein binding to a substrate based on the reactive site of a factor Xa inhibitor isolated from Bauhinia ungulata seeds. Immunopharmacology. v. 45. (1-3) p. 145-149. (1999).

OLIVA, M.L.V.; SOUZA-PINTO, J.C.; BATISTA, I.F.C.; ARAÚJO, M.S.; SILVEIRA, V.F.; AUERSWALD, E.A.; MENTELA, R.; ECKERSON, C.; SAMPAIO, M.U.; SAMPAIO, C.A.M. Leucaena leucocephala serine protease inhibitor: primary structure and action on blood coagulation, kinin release and rat paw edema. Biochimica et Biophysyca Acta. v.1477. p.64-74. (2000)

POPOCA, J.; AGUILAR, A.; ALONSO, D.; VILLARREAL, M.L. Cytotoxic activity of selected plants used as antitumorals in Mexican traditional medicine. Journal of Ethnopharmacology. v. 59. p. 173-177. (1998).

POWERS, J.C.; ASGIAN, J.L.; EKICI, O.D.; JAMES, K.E.Irreversible Inhibitors of Serine, Cysteine, and Threonine Proteases. Chem. Rev., v. 102 p. 4639-4750. (2002). 
RICHARDSON, M. Seed Storage Proteins: The enzyme Inhibitors. Methods in Plant Biochemistry. v. 5. p.259-305. (1991).

RYAN, C.A. Protease Inhibitors in Plants: Genes for Improving Defenses Against Insects and Pathogens. Annu. Rev. Pythopathol.. v. 28. p. 425-449. (1990).

SCHAGGER, H.; JAGOW, G.V.; Tricine-Sodium Dodecyl Sulfate-Polyacrilamide Gel Electrophoresis for the separation of proteins in the range from 1 to $100 \mathrm{kDa}$. Anal. Biochem. v. 166. p. 368-379. (1987).

SCHULTZ, A.R.H.. Introdução à botânica sistemática. Edt. da Universidade, UFRGS 5.ed. Porto Alegre. (1985).

SHEWRY, P.R.; LUCAS, P.R. Plant protein that confer resistance to pests and pathogens. Adv. Bot. Res. v. 26 p.135-192. (1997).

SIMÕES, I.; FARO, C. Structure and function of plant aspartic proteinases. Eur. J. Biochem, v. 271. p. 2067-2075. (2004).

SREERAMA et al. Estimation of the number of $\alpha$-helical and $\beta$-strand segments in proteins using CD spectroscopy. Protein Science. v. 8. p. 370-380. (1999).

SREERAMA, N., VENYAMINOV, S.Y., WOODY, R.W. Analysis of protein circular dichroism spectra based on the tertiary structure classification. Anal. Biochem. v. 299. p. 271-274. (2001).

SREERAMA, N., VENYAMINOV, S.Y., WOODY, R.W. Estimation of protein secondary structure from circular dichroism spectra: comparison of CONTIN, SELCON, and CDSSTR methods with and expanded reference set; Anal Biochem. v. 287. p. 252-260. (2000).

SREERAMA, N.; WOODY, R.W. Structural composition of $\beta_{\mathrm{I}}$ and $\beta_{\mathrm{II}}$-proteins. Protein Sci. v. 12. p. 384-388. (2003). 
TAN, C.G.L.; STEVENS, F.C. Amino Acid sequence of lima bean protease inhibitor component IV. Isolation and sequence determination of the tryptic peptides. European Journal of Biochemistry. v. 18. p. 503-514. (1971).

TELES, R.C.L.; SOUZA, E.M.T.; CALDERON, L.A.; FREITAS, S.M. Purifications and pH stability characterization of a chymotrypsin inhibitor from Schizolobium parahyba seeds. Phytochemistry. v. 65. p. 793-799. (2004).

VARGAS, F.D.; VALDES, H.E.L.; RODRÍGUEZ, S.V.; LABRA, A.B.; LÓPEZ, A.C.; VALENZUELA, E.J.L. Isolation and properties of a Kunitz-type protein inhibitor obtained from Pithecellobium dulce seeds. Journal of Agriculturan and Food Chemistry. v. 52. p. 6115-6121. (2004)

VOET, D.; VOET, J.G.; PRAT, C.W. Fundamentos de Bioquímica. Edt. Artmed. 1.ed. Porto Alegre. p. 307-319. (2000).

WILSON, W.D. Analyzing Biomolecular Interactions. Science. v. 295. p. 2103-2105. (2002).

WOODY, R.W. Aromatic side-chain contributions to the far ultraviolet circular dichroism of peptides and proteins. Biopolymers. v. 17. p. 451-467. (1978).

WU, H.C.; LIN, J.Y. The complete amino acid sequence of a Kunitz family trypsin inhibitor from the seeds of Acacia confusa. J. Biochem. v. 113. p. 258-263. (1993).

WU, Q.; KUO, H.C.; DENG, G.G. Serine proteases and cardiac function. Biochimica et Biophysica Acta (BBA) - Proteins \& Proteomics. v. 1751 (1). p.82-94. (2005).

XIE, W.Z.; LEIBL, M.; CLARK, M.R.; DOHRMANN, P.; KUNZE, T.; GIESELER, F. Activation of the coagulation system in cancerogenesis and metastasation. Biomedicine \& Pharmacotherapy. v. 59 p. 70-75. (2005). 
YANG et al. Calculation of protein conformation from circular dichroism. Meth. Enzymol., v. 130. p. 208-269. (1986).

YENI, P. Update on HAART in HIV. Journal of Hepatology. v. 44 (1). p.100-103. (2006).

ZHAO, Y.; JIN, Y.; WEI, S.S.; LEE, W.H.; ZHANG, Y. Purification and characterization of an irreversible serine protease inhibitor from skin secretions of Bufo andrewsi. Toxicon, v. 46 (6). p. 635-640. (2005).

INTERNET

http://www.matrixscience.com 